SF

973

K 3

Kenyon, Hon W S

Remedies For Hag Cholera. 


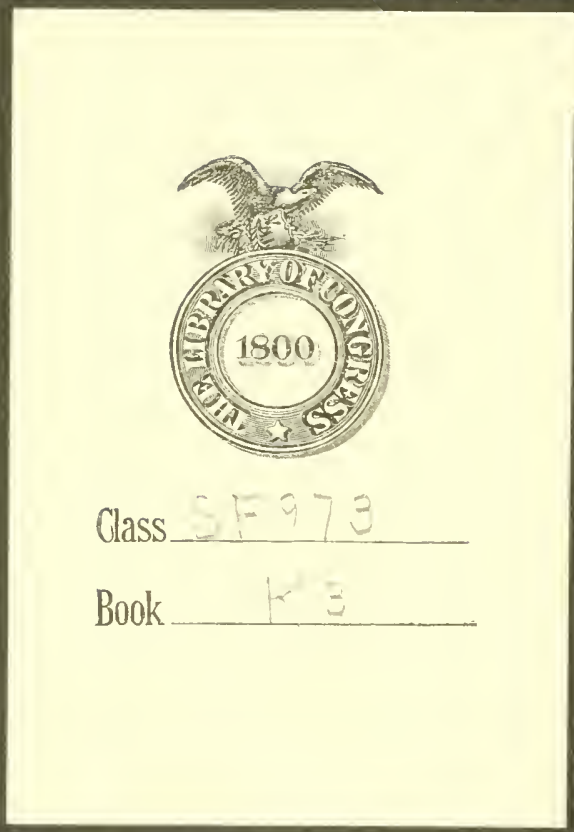




\section{REMEDIES FOR HOG CHOLERA}

\section{SPEECH}

DELIVERED IN THE SENATE OF THE UNITED STATES RELATIVE TO CERTAIN REMEDIES AND PRE-

VENTIVES FOR HOG CHOLERA

ON JANUARY 26, 1914

By

\section{HON. WILLIAM S. KENYON \\ SENATOR FROM IOWA}

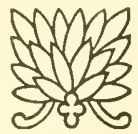

PRESENTED BY MR. NORRIS

JUNE 4, 1914.-Ordered to be printed 


$$
\text { SF } \begin{aligned}
& 9^{12} \\
& k^{2}
\end{aligned}
$$

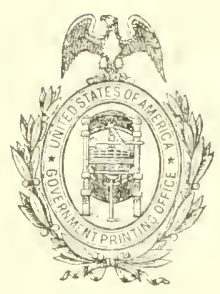

D. of $\mathrm{B}$

J以约 2899 


\title{
REMEDIES FOR HOG CHOLERA.
}

\author{
SPEECH OF HON. WILLIAM S. KENYON, OF IOWA, IN THE SENATE \\ OF THE UNITED STATES, IMONDAY, JANUARY 26, 1914.
}

The Senate had under consideration the bill (S. 3439) appropriating funds for the purpose of providing and administering remedies for hog cholera.

Mr. Kexyox. Mr. President. I do not want to take very much time, and what I say is somewhat sipplemental to what the Senator from Ohio [Mr. Pomerene] has said. But at the same time, I do not want to offer any apology for taking a little of the time of the Senate in presenting the case of the American farmer on this subject.

I read an article in an Ohio paper a few days ago stating that Senators Pomerene and Kenyon would introduce their bill "to abolish hog cholera in the United States Senate on next Thursday." I never knew just what was the matter with the Senate; the paper, I judge, is wrong.

The Washington Times had an editorial on this subject that is very good. I wish to make it a part of my remarks, and am going to ask to have it read by the Secretary at the desk. It states the whole thing, I think, in a nutshell, although the figures as to the appropriation are wrong.

The Presiding Orficer (Mr. Vardaman in the chair). Without objection, the Secretary will read as requested.

(The Secretary read as follows:)

[Washington Times, Januarj 17, 1914.]

JUST PLAIN COMMON SENSE.

Out in Ohio they are starting a sort of national campaign for the extinction of hog cholera, and they want the cooperation of Congress and the state legislatures. Of course, there will never be so much appeal to the imagination in such a commonplace proceeding as there would in something less specific or practical: but it would be a fine thing if some such simple. common-sense things could be taken up and put into execution.

We are worrying about the increasing cost and decreasing supplies of meat. No wonder. Hog cholera alone takes enough meat every year to account for the whole annual discrepancy. But that is not all it does. It is not even the worst it does.

The farmer who raised a drove of hogs right up close to the finishing and marketing point, putting his sear's coln rop into them, and who then, late in the fall, when he has plans matured for sjending the money they are going to bring in, sees them die on his hands, is losing something more than that drove of hogs.

He loses confidence in the hog-raising industry.

It takes more persistence and pertinacity than most men jossess to turn right around after a calamity like that and raise another drove of hogs. The man who suffers from the visitation of cholera is very likely not to have left even the basis on which to begin producing a new herd: he is pretty certain, in any case, not to retain much enthusiasu about doing it. 
Therefore it is common experience that the farmer who this year loses 50 hogs will probably in the next two or three years produce 200 fewer bogs than he would but for this present loss. "That is to say, if hog cholera takes $\$ 100$,000,000 worth of hogs a rear. as some of the statisticians say, it prevents the raising of two or three times that much more. And that means the difference between adequate and inalequate meat sumplies for the country.

The fact is that if hog cholera comld he abolished by an executive decree, the United States womld in two gears be restored to its old place as the greatest meat-exporting country in the world. To-bay on exports a re practically wiped out.

Senator lienyon some time ano introdnced a bill to appropriate $\$ 5,000,000$ for the conduct of the Agliontural Department's campign to eladicate hog cholera. It should be nnderstood that eralication is no chimera. Remedies have been dereloped, methods devised, that in time, backed by enough money and authorits, womld well-nigl exterminate the germs of the disease. But there can be no general results without those two thins-money and rigorous anthority.

Probably the world has got wise and liberal enongh hy this time to assure that such a measure as this would not he defeated with the smeering suggestion that it was " wiving the farmel" a few more millions." It is not more than nominally a service to the famer. The farmer can do a lot of other things aside from raising hogs. Just at present, with corn worth around 70 cents, it is hard enough to keep the farmer convinced that it is worth while to turn the corn into meat. It takes a rood deal less work and risk to haul the com to town and sell it. That the country needs is means to keep the farmer in the mind of raising logs, and the thing that would encourage him more than anything else would be the assurauce that his chature of loss by cholera was going to be reduced rear by rear.

An apropriation for the stamping ont of cholera would be an appropriation to do the most practical work possible in the direction of increasing the national meat sulply.

Mr. Kexyox. I think possibly that that editorial states the situation better than I can, but I am so intensely interested in this question and it so affects my state that I wish to present a few facts in relation to it.

The question of the high cost of living is one that is interesting everybody and to which the people are giving a rery deep study. While it may not seem to comport with the dignity of this body to discuss hog cholera, yet the losses from hog cholera have been so appalling in this countris that it has become a subject which must attract the attention of the National Congress. It has gone beyond all State lines and becomes a national problem, and it is an important problem to the great industry of agriculture. which produced last year farm products exceeding $\$ 6,000,000,000$ in value.

This proposition also is a great economic proposition. It goes to the question of the cost of living. It goes to the question of something to eat for the people, and that is just as important as any Alaskan railway or any Mexican question or any tariff or currency question.

As suggested by the Senator from Ohio [Mr. Pomerene]. I do not beliere that Members of Congress appreciate what a tremendous loss there has been in this country due to hog cholera. We have a great interest in the farmers of this country. especially at election times, but if tre have that deroted interest to the farmer we have a chance in helping him now to show what that interest really is.

Prof. Kennedy, of the agricultural college at Ames, in my State, made a statement relating to the loss of hogs from cholera during the year 1912 which is rather astounding. He said:

The national hog-cholera loss last year was $\$ 00,000.00001^{\circ} 1,000,000.000$ pounds of meat. This was 10 pounds per catpita. Iowa's loss was $150,000,000$ pounds, or 62 pounds per person, and was more this gear. 


\section{He further stated that-}

Iowa's loss this year would be $\$ 20,000,000 . * * *$ It is a great feature in the high cost of living. and I am for liberal Federal aid in the elimination of how cholera.

On yesterday I received a letter from Prof. Kennedy in which he placed the loss for the year 1913 as rather high. He says he sent out letters to every bank cashier in towns of 10,000 , and in relation to it he received 1,120 replies.

By actual count-

He says-

Dallas County-

\section{One of the counties in our State-}

this year lost about 20,000 head, or about $16 \frac{2}{3}$ per cent. The data which we gathered would indicate about 17 per cent loss, so you can see that our reports are fairly accurate. I think it is putting it very low to say that the farmers of Iowa, during 1913, lost at least $\$ 30,000,600$ through hog cholera.

I think that is too high, but he estimates three sources of loss.

One is the direct loss from the hogs which die-

Which in this country would amount to 10 pounds of meat for every man, woman, and child-

Second. the direct liss from the marketing of pigs in a half-fat condition, thus sold at a sacrifice; third, the indirect loss to the cattle feeder, who loses a considerable amomt of his feed by not having the hogs to follow his cattle.

I am going to discuss that in a moment as one of the matters entering vitally into the cause of the high cost of living. I shall ask permission to make this letter a part of my remarks.

The Presiding Orficer. Without objection, it is so ordered.

(The letter referred to is as follows:)

Senator W. S. Kexyon, Washington, D.C.

AMES, Iow A, January 19, 1914.

DeAR SENATOR KENYon: Inder separate cover I am sending rou a hog-cholera report for the year 1913. This data was collected ly the agricultural extension department in order that we might ascertain so far as possible the loss from hog cholera during the year 1913, also to have a comparison of 1913 with 1912. In order to get this data I sent out letter's to every bank cashier in towns of 10,000 and under, asking them three questions: First, what wats the porcentage of logs which died from hog cholera in their vicinity during tle year 1913: second, what percentage of the hogs were marketed early-sar, weighing between 50 and 150 pounds-due to the hog-cholera scare; third, how the loss compared with that of 1912 .

We have received $\mathbf{1 . 1 2 0}$ replies, representing every connty in Iowa. I have the data tabulated in the report which I am sending, you. I beliere that the number of hogs stated in the different counties is too low. For instance, in Dallas County the report shows 93,\$52 head. A farm-to-farm canvas made by our department for the Tnited states Department of Agriculture, in connection with this hog-choler'a work there this rear, showed that there were 120,000 head of hogs in Dallas County. By actual comnt Iallas County this year lost about 20.000 head, or about $16_{3}^{2}$ per rent. 'The lata which we gathered would indicate about 17 per cent loss; so rou can see that our reports are fairly accurate. I think it is putting it rery low to say that the farmers of Iowa during 1913 lost at least $\$ 30,000,000$ through hog cholera.

There are three sonces of loss: One is the direct loss from the hogs which die; second. the direct loss from the marketing of pigs in a lalf-fat condition, thus sold at a sacrifice; third, the indirect loss to the cattle feeder, who loses a considerable amount of his feed by not having the hogs to follow his cattle. 
I assure you that this is an important subject in Iowa. In my judgment, you can do our people a great deal of good by having a law passed demanding Federal testing of every drop of selum made in the commercial plants. This, in my judgment, is the first step in the hog-cholera work. Every man with whom I have talked feels that this is the case. I assure you that we will be glad to help you in any way possible. I am,

Very truly, yours,

IV. J. KENNEDY.

Mr. Kenron. In going over the records of hog losses in this country, and after consultation with the Bureau of Animal Industry on the subject, I learn that practically 90 per cent of all losses of swine that occur each year are due to a disease known as hog cholera, and if this be the case, as it undoubtedly is, the loss is appalling, and it is certainly time for us to provide some means for the eradication of the disease, if such a thing is possible. I do not know just what is best. We can only judge of that by the experts of the Agricultural Department and the farmers, but I am in favor of a large appropriation being placed at the disposal of the Department of Agriculture for them to use in snch way as they deem fit.

We have placed $\$ 10,000,000$ practically in the hands of the President of the United States to build railroads in Alaska. This proposition is far more important than any railroad in Alaska, and the losses of one vear, if saved, would build three times the amount of railroad we are going to construct in Mlaska.

So we can likewise have confidence in the Secretary of Agriculture to use this money wisely and to accomplish the purposes intended.

Hog cholera made its first appearance in this country in the State of Ohio, brought in by the importation from some foreign countries of blooded stock, and as Ohio has that mpleasant distinction, it now has the better distinction of being the State that has appropriated more to help solve this problem than any other State in the Union, having appropriated $\$ 100,000$ for a serum plant-more money than the Govermment has appropriated in the last 10 years on this question.

This disease has gradually extended throughont the country until now there is scarcely a state in the Union free from its ravages. Transportation lines have unwittingly and unknowingly helped to carry this disease by the fact that cars were not properly cleaned and "fumigated. If no method is found to check this disease the farmers will cease to raise hogs. as a farmer will not run the risk of having the herd which represents his time and represents his crop absolutely wiped away in a week or ten days by this scourge. If the farmer does that the cost of living is going up to a point where even our. Democratic friends can not explain it.

I have prepared a map showing the losses in the varions States from hog cholera in the year 1912. It shows the money expended by the varions States in fighting the disease, the number of swine raised in those various States. and the recommentation of those various States as to the governmental appropriation. I want to call the attention of the Senate to just a few of the statements. This is not a northern matter entirely.

I have had letters from experts from the State of Georgia stating that the question is becoming a live one in the State of Georgia. During the year 1913 the State of Georgia lost 165 ont of every thousand hogs. In the year previous the loss was 90 out of every thousand. So the loss in Georgia in one year's time increased nearly 100 per cent. 
In the State of Florida in 1913 the loss was 170 out of every thousand. The previous year the loss was 100 out of every thousand, an increase of 70 per cent in the State of Florida.

In the State of Alabama in 1913 the loss was 110 out of every thousand. In the previous year the loss was 65 out of every thousand, showing an increase of nearly 100 per cent in the State of Alabama.

In the State of Louisiana in 1913 the loss was 110 out of every thousand. In the previous year it was 100 .

In the State of Arkansas in 1913 the loss was 160 out of every thousand. In the previous year 140 .

Mississippi lost 154 ont of every thousand in 1913. In the previous year in Mississippi the loss was 75 to a thousand, an increase in loss of over 100 per cent.

Taking the States of the far IVest as indicated on the map-

Mr. Orerman. Has the Senator the statistics for North Carolina?

Mr. Kenron. I have the statistics here for Nolth Carolina. For the year ending Jannary 1, 1913, North Carolina lost 69,687 hogs to the value of $\$ 536,589$. Colorado in 1913 lost 100 out of each thousand. The loss of the previous year in Colorado was 20 out of each thousand, being an increase of 500 per cent in the State of Colorado.

Mr. Brady. Mr. President

The Presiding Officer. Does the Senator from Iowa yield to the Senator from Idaho?

Mr. Kényon. I do.

Mr. Bradr. Has the Senator any information as to the loss in 1913 ?

Mr. Kenyon. I have it for my own State, and I have statistics as to the year ending March 31. 1913. I have no figures later than that.

Mr. Bradx. I notice that the loss to Idaho in 1912, according to the figures on the map. was something over 7,000. The loss probably was several times as great the past year.

Mr. Ken ron. I am satisfied that is true.

Mr. Bradr. I wondered whether the Senator has the exact figures.

Mr. Kenyon. I have not. but judging from the increase in our own State the loss in Idaho must have increased that much.

The State of Indiana in 1912 lost 150 out of each thousand: Illinois, 140 ont of each thousand; Nebraska, 110; Kansas, 120; Missouri, 175 out of each thousand, nearly one-fifth of all the swine within the borders of that State. The loss in Missouri has been more in proportion, slightly so, to the number of swine than in any other State for the year 1912, but the Government is making experiments now in Missouri. Indiana, and Iowa. Iora lost 160 out of each thousand. 'The previous year the loss was 80 , which showed an increase of 100 per cent.

I desire to have inserted in the Record this statement of the condition of hogs April 1, and the estimated loss during the year ending March 31, 1913, from which I have just read. It is the latest, I will say to the Senator from Idaho, I have. These figures were obtained from the crop reports for 1913, and I wish to make them a part of my remarks.

The Presiding Ofricer. If there is no objection, it will be so ordered. 
(The matter referred to is as follows:)

Condition of hogs Apr. 1 and estimated losses during the year ending Mar. 31, 1913, with comparisons.

\begin{tabular}{|c|c|c|c|c|c|c|c|c|}
\hline \multirow[b]{2}{*}{ State and division. } & \multicolumn{4}{|c|}{ Losses from disease. } & \multicolumn{3}{|c|}{ Condition A pr. 1.} & \multirow{2}{*}{$\begin{array}{c}\text { Breed- } \\
\text { ing } \\
\text { sows. }\end{array}$} \\
\hline & $1913^{1}$ & 19121 & $\begin{array}{c}\text { 10-year } \\
\text { aver- } \\
\text { age. }\end{array}$ & Number. & 1913 & 1912 & $\begin{array}{c}\text { 10-year } \\
\text { aver- } \\
\text { age. }\end{array}$ & \\
\hline 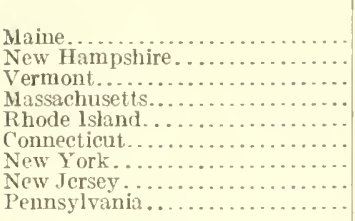 & $\begin{array}{r}\text { Pr. } c t \text {. } \\
25 \\
25 \\
19 \\
40 \\
25 \\
30 \\
30 \\
40 \\
43\end{array}$ & $\begin{array}{r}\text { Pr. } \\
15 \\
20 \\
39 \\
35 \\
18 \\
48 \\
29 \\
40 \\
37\end{array}$ & $\begin{array}{r}\text { Pr. } c t . \\
14 \\
17 \\
20 \\
22 \\
21 \\
26 \\
22 \\
28 \\
29\end{array}$ & $\begin{array}{r}2,828 \\
1,300 \\
2,033 \\
4,600 \\
350 \\
1,740 \\
22,830 \\
6,400 \\
45,590\end{array}$ & $\begin{array}{r}\text { Pr. } c t . \\
97 \\
95 \\
99 \\
95 \\
97 \\
97 \\
98 \\
97 \\
96\end{array}$ & $\begin{array}{r}\text { Pr. } c t . \\
98 \\
98 \\
99 \\
96 \\
97 \\
98 \\
96 \\
95 \\
93\end{array}$ & $\begin{array}{r}\text { Pr. } c t . \\
98 \\
98 \\
99 \\
98 \\
98 \\
99 \\
98 \\
97 \\
96\end{array}$ & $\begin{array}{r}\text { Pr. } c t . \\
95 \\
93 \\
98 \\
94 \\
93 \\
97 \\
95 \\
96 \\
95\end{array}$ \\
\hline North Atlantic............ & 36.3 & 33.7 & 25.0 & $90,6 \pi 1$ & 96.8 & 94.9 & 97.2 & 95.1 \\
\hline 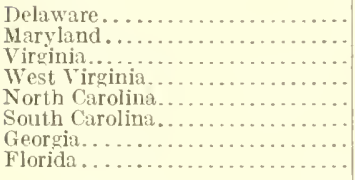 & $\begin{array}{r}50 \\
90 \\
14 \\
73 \\
58 \\
75 \\
165 \\
170\end{array}$ & $\begin{array}{r}80 \\
75 \\
40 \\
41 \\
44 \\
60 \\
90 \\
100\end{array}$ & $\begin{array}{l}47 \\
37 \\
15 \\
32 \\
60 \\
60 \\
66 \\
79\end{array}$ & $\begin{array}{r}2,900 \\
30,150 \\
40,125 \\
25,945 \\
77,430 \\
57,375 \\
311,520 \\
149,260\end{array}$ & $\begin{array}{l}92 \\
91 \\
95 \\
94 \\
94 \\
90 \\
92 \\
92\end{array}$ & $\begin{array}{l}92 \\
91 \\
92 \\
94 \\
94 \\
90 \\
90 \\
92\end{array}$ & $\begin{array}{l}94 \\
95 \\
95 \\
95 \\
94 \\
94 \\
94 \\
93\end{array}$ & $\begin{array}{r}97 \\
94 \\
98 \\
100 \\
98 \\
97 \\
91 \\
91\end{array}$ \\
\hline South Atlantic............ & 107.7 & 68.8 & 57.5 & 694,751 & 92.8 & 91.6 & 94.2 & 94.7 \\
\hline 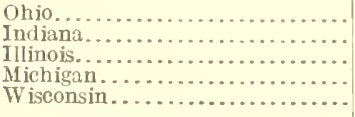 & $\begin{array}{r}86 \\
150 \\
140 \\
40 \\
28\end{array}$ & $\begin{array}{r}70 \\
125 \\
215 \\
40 \\
28\end{array}$ & $\begin{array}{l}46 \\
68 \\
71 \\
31 \\
24\end{array}$ & $\begin{array}{r}292,314 \\
556,350 \\
604,100 \\
52,520 \\
56,840\end{array}$ & $\begin{array}{l}94 \\
89 \\
91 \\
94 \\
96\end{array}$ & $\begin{array}{l}90 \\
88 \\
85 \\
95 \\
97\end{array}$ & $\begin{array}{l}95 \\
94 \\
95 \\
96 \\
96\end{array}$ & $\begin{array}{r}100 \\
95 \\
108 \\
96 \\
99\end{array}$ \\
\hline $\begin{array}{l}\text { North Central east Missis- } \\
\text { sippi River . . . . . . . . . . . }\end{array}$ & 105.8 & 118.9 & 55.6 & $1,562,124$ & 92.1 & 89.4 & 95.0 & 100.2 \\
\hline 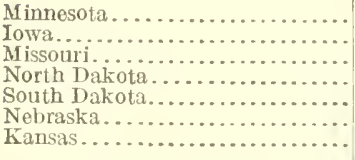 & $\begin{array}{r}55 \\
160 \\
175 \\
20 \\
38 \\
110 \\
120\end{array}$ & $\begin{array}{r}30 \\
80 \\
160 \\
15 \\
38 \\
60 \\
132 \\
\end{array}$ & $\begin{array}{l}30 \\
54 \\
74 \\
17 \\
54 \\
63 \\
50\end{array}$ & $\begin{array}{r}93,610 \\
1,395,200 \\
715,225 \\
7,320 \\
44,875 \\
417,780 \\
313,320\end{array}$ & $\begin{array}{l}96 \\
89 \\
84 \\
94 \\
95 \\
93 \\
91\end{array}$ & $\begin{array}{l}97 \\
91 \\
82 \\
98 \\
96 \\
94 \\
84\end{array}$ & $\begin{array}{l}97 \\
96 \\
93 \\
98 \\
96 \\
96 \\
94\end{array}$ & $\begin{array}{r}105 \\
95 \\
101 \\
105 \\
107 \\
101 \\
119\end{array}$ \\
\hline $\begin{array}{l}\text { North Central west Missis- } \\
\text { sippi River.............. }\end{array}$ & 133.0 & 90.9 & 56.5 & $2,987,333$ & 90.0 & 89.8 & 95.3 & 101.2 \\
\hline 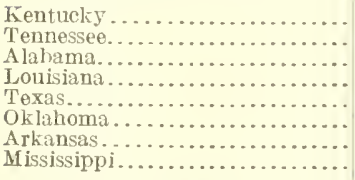 & $\begin{array}{r}95 \\
99 \\
110 \\
110 \\
45 \\
81 \\
160 \\
154\end{array}$ & $\begin{array}{r}70 \\
70 \\
65 \\
100 \\
34 \\
145 \\
140 \\
75\end{array}$ & $\begin{array}{l}60 \\
59 \\
60 \\
91 \\
37 \\
64 \\
92 \\
62\end{array}$ & $\begin{array}{l}155,610 \\
145,005 \\
168,160 \\
155,320 \\
112,185 \\
107,325 \\
244,640 \\
225,228\end{array}$ & $\begin{array}{l}90 \\
89 \\
92 \\
88 \\
94 \\
85 \\
87 \\
91\end{array}$ & $\begin{array}{l}89 \\
90 \\
92 \\
84 \\
90 \\
79 \\
84 \\
90\end{array}$ & $\begin{array}{l}93 \\
94 \\
94 \\
91 \\
95 \\
92 \\
90 \\
94\end{array}$ & $\begin{array}{r}94 \\
90 \\
93 \\
95 \\
105 \\
120 \\
95 \\
90\end{array}$ \\
\hline South Central............ & 102.2 & $\$ 3.5$ & 60.4 & $1,311,473$ & 90.2 & 87.5 & 93.2 & 97.3 \\
\hline 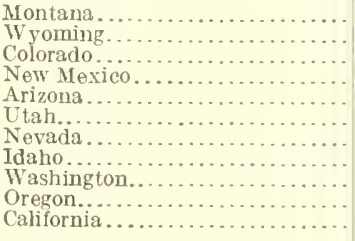 & $\begin{array}{r}20 \\
15 \\
100 \\
27 \\
13 \\
24 \\
21 \\
37 \\
22 \\
30 \\
50\end{array}$ & $\begin{array}{l}19 \\
12 \\
20 \\
16 \\
12 \\
16 \\
24 \\
14 \\
22 \\
16 \\
25\end{array}$ & $\begin{array}{l}20 \\
18 \\
21 \\
19 \\
28 \\
20 \\
22 \\
17 \\
18 \\
17 \\
37\end{array}$ & $\begin{array}{r}3,060 \\
615 \\
20,500 \\
1,404 \\
299 \\
1,944 \\
672 \\
8,621 \\
5,676 \\
8,040 \\
41,100\end{array}$ & $\begin{array}{r}97 \\
100 \\
94 \\
97 \\
98 \\
99 \\
98 \\
96 \\
98 \\
98 \\
97\end{array}$ & $\begin{array}{l}98 \\
99 \\
98 \\
95 \\
99 \\
9.9 \\
97 \\
99 \\
98 \\
99 \\
97\end{array}$ & $\begin{array}{l}98 \\
99 \\
98 \\
95 \\
95 \\
98 \\
98 \\
98 \\
98 \\
98 \\
97\end{array}$ & $\begin{array}{r}110 \\
107 \\
100 \\
104 \\
105 \\
100 \\
101 \\
113 \\
106 \\
107 \\
97\end{array}$ \\
\hline Far Western....... & 42.4 & 20.6 & 25.8 & 91,931 & 97.0 & 97.8 & 97.6 & 102.4 \\
\hline United States............. & 110.1 & $\$ 9.2$ & 54.9 & $6,735,2 \triangleleft 3$ & 91.4 & $\$ 9.9$ & 94.8 & 99.1 \\
\hline
\end{tabular}

Loss by cholera in 1912, $\$ 60,000,000$. 
Mr. Kenrox. I want also to place in the Record a table showing the estimated number, the average price, and the total value of swine in the United States January 1, 1913, with comparisons; also a table showing the estimated loss there given for the same vear. I will not take the time to read these figures. but I should like to have the table printed.

The Presiding Officer. Withont objection, the request will be granterl.

The tables referred to are as follows:

Estimated number, average price, and total value of swine in the United states Jan. 1, 1913, with comparisons.

\begin{tabular}{|c|c|c|c|c|c|c|c|}
\hline \multirow{2}{*}{ State and division. } & \multicolumn{2}{|c|}{ Number Jan. 1, 1913.} & \multicolumn{3}{|c|}{ A verage price per head Jan. 1.} & \multirow{2}{*}{$\begin{array}{c}\text { Total value } \\
\text { Jan. 1, } \\
1913 .\end{array}$} & \multirow{2}{*}{$\begin{array}{l}\text { A verage } \\
\text { age when } \\
\text { mar- } \\
\text { keted.2 }\end{array}$} \\
\hline & $\begin{array}{c}\text { Per } \\
\text { cent. } 1\end{array}$ & Total. & 1913 & 1912 & $\begin{array}{l}\text { 10-year } \\
\text { average. }\end{array}$ & & \\
\hline 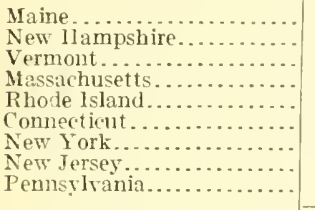 & $\begin{array}{r}100 \\
95 \\
96 \\
98 \\
90 \\
97 \\
98 \\
97 \\
99\end{array}$ & $\begin{array}{r}101,000 \\
52,000 \\
107,000 \\
115,000 \\
14,000 \\
58,000 \\
7+1,000 \\
11 ; 0,000 \\
1,120,000\end{array}$ & $\begin{array}{l}\$ 12.90 \\
12.70 \\
12.20 \\
13.00 \\
14.50 \\
14.00 \\
12.60 \\
13.00 \\
12.50\end{array}$ & $\begin{array}{r}\$ 11.50 \\
10.50 \\
10.00 \\
11.30 \\
12.00 \\
11.60 \\
10.20 \\
11.30 \\
10.00\end{array}$ & $\begin{array}{r}\$ 10.10 \\
10.40 \\
9.10 \\
10.40 \\
11.40 \\
11.70 \\
9.70 \\
11.10 \\
9.30\end{array}$ & $\begin{array}{r}81,303,000 \\
660,000 \\
1,305,000 \\
1,495,000 \\
203,000 \\
812,000 \\
9,584,000 \\
2,080,000 \\
14,125,000\end{array}$ & $\begin{array}{r}9.0 \\
9.0 \\
9.0 \\
9.8 \\
9.8 \\
9.5 \\
9.0 \\
10.0 \\
10.0\end{array}$ \\
\hline North Atlantic....... & 98.3 & $2,498,000$ & 12.64 & 10.32 & 9.69 & $31,5 \pi 2,000$ & 9.6 \\
\hline 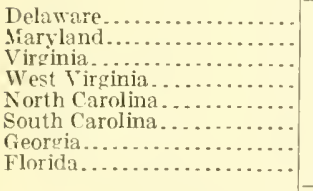 & $\begin{array}{l}98 \\
97 \\
95 \\
95 \\
95 \\
96 \\
90 \\
92\end{array}$ & $\begin{array}{r}58,000 \\
335,000 \\
836,000 \\
356,000 \\
1,335,000 \\
765,000 \\
1,848,000 \\
878,000\end{array}$ & $\begin{array}{r}11.20 \\
9.80 \\
7.00 \\
9.00 \\
7.70 \\
8.50 \\
7.10 \\
5.90\end{array}$ & $\begin{array}{l}7.20 \\
8.00 \\
6.30 \\
6.70 \\
7.40 \\
8.00 \\
6.70 \\
5.20 \\
\end{array}$ & $\begin{array}{l}8.30 \\
7.70 \\
5.70 \\
6.50 \\
5.90 \\
6.40 \\
5.90 \\
3.90\end{array}$ & $\begin{array}{r}650,000 \\
3,283,000 \\
5,852,000 \\
3,204,000 \\
10,280,000 \\
6,502,000 \\
13,405,000 \\
5,180,000 \\
\end{array}$ & $\begin{array}{l}10.0 \\
10.0 \\
11.0 \\
11.6 \\
11.6 \\
12.5 \\
12.0 \\
13.0\end{array}$ \\
\hline South Atlantic...... & 93.5 & $6,451,000$ & 7.50 & 6.80 & 5.95 & $48,356,000$ & 11.8 \\
\hline 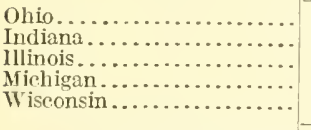 & $\begin{array}{l}95 \\
92 \\
93 \\
95 \\
99\end{array}$ & $\begin{array}{l}3,399,000 \\
3,709,000 \\
4,315,000 \\
1,313,000 \\
2,030,000\end{array}$ & $\begin{array}{r}10.80 \\
9.80 \\
10.50 \\
10.80 \\
11.60\end{array}$ & $\begin{array}{l}8.20 \\
7.70 \\
8.80 \\
8.50 \\
9.00\end{array}$ & $\begin{array}{l}7.40 \\
7.40 \\
8.20 \\
5.20 \\
8.80\end{array}$ & $\begin{array}{r}36,709,000 \\
36,348,000 \\
45,308,000 \\
14,180,000 \\
23,548,000 \\
\end{array}$ & $\begin{array}{r}9.5 \\
9.6 \\
10.0 \\
9.0 \\
9.1 \\
\end{array}$ \\
\hline $\begin{array}{l}\text { North Central east of } \\
\text { Mississippi River... }\end{array}$ & 94.2 & $14,766,000$ & 10.57 & 8.52 & 8.001 & $156,093,000$ & 9.6 \\
\hline 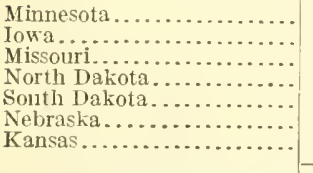 & $\begin{array}{r}100 \\
90 \\
91 \\
102 \\
107 \\
89 \\
93\end{array}$ & $\begin{array}{r}1,702,000 \\
8,720,000 \\
4,087,000 \\
366,000 \\
1,1 \times 1,000 \\
3,798,000 \\
2,611,000 \\
\end{array}$ & $\begin{array}{r}12.70 \\
12.00 \\
8.50 \\
13.70 \\
11.00 \\
11.40 \\
10.40\end{array}$ & $\begin{array}{r}10.40 \\
9.80 \\
7.00 \\
10.50 \\
5.90 \\
8.80 \\
7.90\end{array}$ & $\begin{array}{l}8.80 \\
8.60 \\
6.30 \\
8.90 \\
8.50 \\
8.10 \\
7.60\end{array}$ & $\begin{array}{r}21,615,000 \\
104,640,000 \\
34,740,000 \\
5,014,000 \\
12,991,000 \\
43,297,000 \\
27,154,000 \\
\end{array}$ & $\begin{array}{l}10.0 \\
10.7 \\
10.7 \\
10.7 \\
10.5 \\
11.0 \\
10.5\end{array}$ \\
\hline $\begin{array}{l}\text { North Central west of } \\
\text { Mississippi River... }\end{array}$ & 92 & $22,465,000$ & 11.10 & 8.90 & 7. 99 & $249,451,000$ & 10.7 \\
\hline 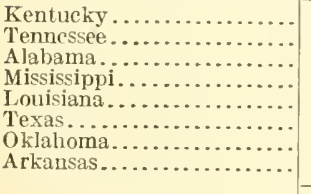 & $\begin{array}{l}95 \\
95 \\
95 \\
94 \\
86 \\
98 \\
94 \\
88\end{array}$ & $\begin{array}{l}1,63 \mathrm{~S}, 000 \\
1,495,000 \\
1,456,000 \\
1,4 \times 2,000 \\
1,412,000 \\
2,493,000 \\
1,325,000 \\
1,529,000 \\
\end{array}$ & $\begin{array}{l}7.10 \\
7.40 \\
6.80 \\
6.90 \\
7.00 \\
8.40 \\
8.90 \\
6.70\end{array}$ & $\begin{array}{l}5.40 \\
6.10 \\
6.50 \\
6.50 \\
5.80 \\
6.30 \\
5.50 \\
5.40\end{array}$ & $\begin{array}{l}5.40 \\
5.50 \\
5.20 \\
5.10 \\
5.10 \\
5.60 \\
6.10 \\
4.30\end{array}$ & $\begin{array}{r}11,630,000 \\
11,063,000 \\
9,901,000 \\
10,226,000 \\
9,884,000 \\
20,941,000 \\
11,792,000 \\
10,244,000 \\
\end{array}$ & $\begin{array}{l}10.5 \\
12.0 \\
13.0 \\
13.0 \\
15.0 \\
12.6 \\
12.0 \\
14.0\end{array}$ \\
\hline South Central........ & 93.4 & $12,830,000$ & 7.46 & 5.95 & 5.35 & $95,6 \$ 1,000$ & 12.7 \\
\hline 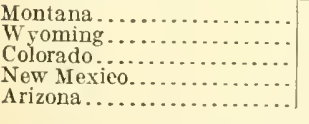 & $\begin{array}{r}107 \\
95 \\
97 \\
103 \\
103\end{array}$ & $\begin{array}{r}153,000 \\
41,000 \\
205,000 \\
52,000 \\
23,000\end{array}$ & $\begin{array}{r}11.90 \\
11.00 \\
11.00 \\
9.60 \\
11.50\end{array}$ & $\begin{array}{r}9.90 \\
8.60 \\
8.00 \\
8.20 \\
10.50\end{array}$ & $\begin{array}{l}9.60 \\
\$ .80 \\
8.10 \\
7.30 \\
8.10\end{array}$ & $\begin{array}{r}1,821,000 \\
451,000 \\
2,255,000 \\
499,000 \\
264,000\end{array}$ & $\begin{array}{l}11.0 \\
12.0 \\
11.5 \\
11.4 \\
11.5\end{array}$ \\
\hline
\end{tabular}


Estimated number, arerage mice, and total value of swine in the United states Jan. 1. 1913, with comparisons-Continued.

\begin{tabular}{|c|c|c|c|c|c|c|c|}
\hline \multirow{2}{*}{ State and division. } & \multicolumn{2}{|c|}{ Number Jan. 1, 1913.} & \multicolumn{3}{|c|}{ A verage price per head Jan. 1.} & \multirow{2}{*}{$\begin{array}{c}\text { Total value } \\
\text { Jan, I, } \\
\text { 1913. }\end{array}$} & \multirow{2}{*}{$\begin{array}{c}\text { Average } \\
\text { age when } \\
\text { mar- } \\
\text { keted. }\end{array}$} \\
\hline & $\begin{array}{c}\text { Per } \\
\text { cent. }\end{array}$ & Total. & 1913 & 1912 & $\begin{array}{c}\text { 10-year } \\
\text { average. }\end{array}$ & & \\
\hline $\begin{array}{l}\text { Utah............. } \\
\text { Nevada............. } \\
\text { Idaho............. } \\
\text { Washington....... } \\
\text { Oregon........... } \\
\text { California......... }\end{array}$ & $\begin{array}{r}102 \\
105 \\
110 \\
105 \\
104 \\
99\end{array}$ & $\begin{array}{r}81,000 \\
32,000 \\
233,000 \\
258,000 \\
268,000 \\
822,000\end{array}$ & $\begin{array}{r}\$ 11.00 \\
11.00 \\
10.30 \\
11.30 \\
9.50 \\
9.20\end{array}$ & $\begin{array}{r}\$ 9.00 \\
10.50 \\
8.00 \\
9.50 \\
8.50 \\
8.30\end{array}$ & $\begin{array}{r}\$ 8.20 \\
8.70 \\
7.60 \\
8.50 \\
7.00 \\
7.20\end{array}$ & $\begin{array}{r}\$ \$ 91,000 \\
352,000 \\
2,400,000 \\
2,915,000 \\
2,546,000 \\
7,562,000\end{array}$ & $\begin{array}{l}10.5 \\
10.5 \\
11.7 \\
10.0 \\
11.1 \\
13.6\end{array}$ \\
\hline Far Western.. & 102.1 & $2,168,000$ & 10.13 & 8.60 & 7.64 & $21,956,000$ & 12.0 \\
\hline United States.. & 93.5 & $61,178,000$ & 9.86 & 8.00 & 7.28 & $603,109,000$ & 11.0 \\
\hline
\end{tabular}

Estimated number of hogs lost from cholera-lecrage price per hearl. Jan. 1, 1913-Total monetary loss to cach state.

Stale and division.

Maine.

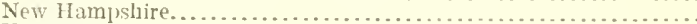

Vermont.

Massachusetts

Rluode Island.

Connecticut.

New Tork.

New Jersey.

Pennsylvania.

North Atlantic.

Delaware.

Maryland.

.......................

West Virginia.

North Carolina.

Solth Carolina.

Georgia.

Florida.

South Atlantie.

Olnio.

Intiana.

Illinois.

Michigan.

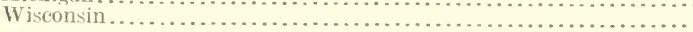

North Central east of Mississippi River .

Minnesota.

Iowa.

Missouri

North Dakota.

Soutli Dakota.

Nebraska.

Kansas.

North Central west of Mississippi River.

Kentucky.

Tennessee

Alabama.

Mississippi.

Louisiana.

Oklahoma

Arkausas.

South Central.

\begin{tabular}{|c|c|c|}
\hline $\begin{array}{c}\text { Estimated } \\
\text { loss of hogs } \\
\text { from } \\
\text { cholera for } \\
\text { jear end- } \\
\text { ing Jall. 1, } \\
1913 .\end{array}$ & $\begin{array}{c}\text { A verage } \\
\text { prices } \\
\text { per head } \\
\text { Jan. 1, } \\
1913 .\end{array}$ & $\begin{array}{l}\text { Monetary } \\
\text { loss to each } \\
\text { State. }\end{array}$ \\
\hline $\begin{array}{r}2,545 \\
1,170 \\
1,829 \\
4,140 \\
315 \\
1,566 \\
20,547 \\
5,760 \\
43,731\end{array}$ & $\begin{array}{r}\$ 12.90 \\
12.70 \\
12.20 \\
13.00 \\
14.50 \\
14.00 \\
12.60 \\
13.00 \\
12.50\end{array}$ & $\begin{array}{r}\$ 32,830 \\
14,859 \\
22,313 \\
53,820 \\
4,567 \\
21,924 \\
258,892 \\
74,880 \\
546,637\end{array}$ \\
\hline 81,403 & . & $1,030,722$ \\
\hline $\begin{array}{r}2,610 \\
27,135 \\
36,115 \\
23,3 \times 9 \\
199,657 \\
51,637 \\
280,365 \\
134,334\end{array}$ & $\begin{array}{r}11.20 \\
9.80 \\
7.00 \\
9.00 \\
7.70 \\
8.50 \\
7.10 \\
5.90\end{array}$ & $\begin{array}{r}29,232 \\
265,923 \\
252,805 \\
210,501 \\
536,589 \\
438,914 \\
1,990,612 \\
792,570\end{array}$ \\
\hline 75 & & $4,517,146$ \\
\hline $\begin{array}{r}263,052 \\
500,715 \\
543,690 \\
47,265 \\
51,156\end{array}$ & $\begin{array}{r}10.80 \\
9.80 \\
10.50 \\
10.80 \\
11.60\end{array}$ & $\begin{array}{r}2, \$ 41,285 \\
4,907,007 \\
5,708,745 \\
510,494 \\
593,409\end{array}$ \\
\hline $1,405,911$ & & $14,560,940$ \\
\hline $\begin{array}{r}\$ 4,249 \\
1,255,680 \\
643,702 \\
6,554 \\
40,390 \\
37,600 \\
281,985\end{array}$ & $\begin{array}{r}12.70 \\
12.00 \\
8.50 \\
13.70 \\
11.00 \\
11.40 \\
10.40\end{array}$ & $\begin{array}{r}1,069,962 \\
15,048,160 \\
5,471,467 \\
90,255 \\
444,290 \\
428,640 \\
2,932,675\end{array}$ \\
\hline $2,350,197$ & . & $25,505,449$ \\
\hline $\begin{array}{r}140,049 \\
133,204 \\
144,141 \\
205,405 \\
139,756 \\
100,966 \\
96,592 \\
220,176\end{array}$ & $\begin{array}{l}7.10 \\
7.40 \\
6.80 \\
6.90 \\
7.00 \\
8.40 \\
8.90 \\
6.70\end{array}$ & $\begin{array}{r}994,347 \\
985,709 \\
980,179 \\
1,417,294 \\
678,516 \\
848,114 \\
859,668 \\
1,475,179\end{array}$ \\
\hline $1,180,324$ & & $8,539,006$ \\
\hline
\end{tabular}


Estimated number of hogs lost from cholera, etc.-Continued.

\begin{tabular}{|c|c|c|c|}
\hline State and division. & $\begin{array}{l}\text { Estimated } \\
\text { loss of hogs } \\
\text { from } \\
\text { cholera for } \\
\text { year end- } \\
\text { ing Jan. 1, } \\
1913 \text {. }\end{array}$ & $\begin{array}{c}\text { A rerage } \\
\text { prices } \\
\text { per head } \\
\text { Jan. } 1 \text {, } \\
1913 .\end{array}$ & $\begin{array}{l}\text { Monetary } \\
\text { loss to each } \\
\text { State. }\end{array}$ \\
\hline 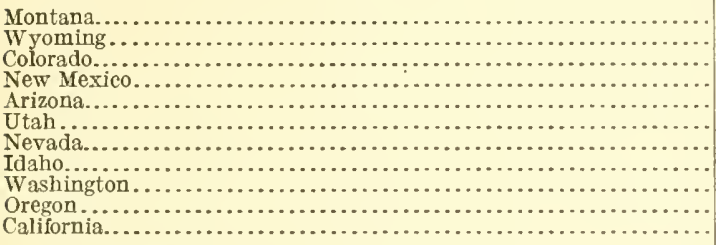 & $\begin{array}{r}2,754 \\
553 \\
18,450 \\
1,263 \\
269 \\
1,749 \\
604 \\
7,758 \\
5,108 \\
7,236 \\
36,990\end{array}$ & $\begin{array}{r}\$ 11.90 \\
11.00 \\
11.00 \\
9.60 \\
11.50 \\
11.00 \\
11.00 \\
10.30 \\
11.30 \\
9.50 \\
9.20\end{array}$ & $\begin{array}{r}\$ 32,772 \\
6,083 \\
202,950 \\
12,124 \\
3,093 \\
19,239 \\
6,644 \\
79,907 \\
57,720 \\
68,742 \\
340,308\end{array}$ \\
\hline Far Western............... & 82,734 & $\ldots \ldots \ldots \ldots$ & $\$ 29,582$ \\
\hline Total for United States.. & $5,730,844$ & & $54,982,825$ \\
\hline
\end{tabular}

Mr. Kenyox. Those who have examined the map will notice that the great losses hare been in what are known as the corn-producing States. Iowa has more hogs than any State in the Union-double the amount. Iowa, Illinois. Missoun'. Indiana, and Ohio have been the chief losers, though Kansas has also been a very heary loser.

I wish to quote from the report of the committee of the Inited States Live Stock Sanitary Association on hog-cholera legislation. This report was submitted to the association December 2. 1913, and I read as follows:

In studying the conditions that cxisted in previons decades, and covering a period of about 40 years, the committee finds that the losses from hog cholerat have very probably averaged nver $\$ 50,000.000$ annually during these decalles.

In 1597 Dr. D. E. Salmon, then Chief of the United States Bureau of Animal Industrs, states in the annual report of that bureau: "The losses (from log cholera) have, howerel, been tremendous. being placed by sume as high as $\$ 100,000,000$ a year, an estimate which does not :ppear exagcerated in the light of the careful inquiries in the state of Iowa. from which it was concluded that this one State lost from $\$ 12,000,000$ to $\$ 15,000,000$ worth of swine in a single year."

FINANCIAL LOSS TREMENDOUS.

Since this loss is a regular annual occul'ence, its meaning can best be blought to us by looking upon it as the lost interest on a mermanent investment. It would require an investment of $\$ 1.250,000,(100$, al 4 per ceut, to yield $\$ 50.000,000$, and since this loss has been going on for at least 40 rears, the total loss lias already exceeded $\$ 2,000,000,000$, or, with compound interest. to more than twice the hypothetical investment of $\$ 1,250,000,000$ referred to. Neasured in the ralue of the finished product (pork), these figures would practically be donbled.

The money involved in these losses would build a transcontinental railroad-

This is a report of this committee-

at $\$ 10,000$ a mile, through the United States every year. or it would support, on a million-dollar-a-rear-income basis, a great university and agricultural experiment station for each State in the Union, and half a dozen extra unversities for such States as need them.

With these figures before us-

\section{Says this report-}

and the problem of the high cost of lising staring us constantly in the face, how many questions are of greater economic importance than that of the control of hog cholera for the prevention of these enormous losses? 
Now, mind you, the statement of Dr. D. E. Salmon, dates back to the year 1897, and this great loss has been going on ever since that time, and I am credibly informed that the loss in Iowa for the year 1913 will be something like $\$ 20,000,000$, and that our neighboring State of Missouri will suffer a loss of something like $\$ 10,000,000$ for the same year.

I have heretofore stated that Prof. Kennedy estimated the loss in our State for 1913 at $\$ 30,000,000$.

Mr. Warren. What date was that?

Mr. Kenrox. 'This report is December 2, 1913.

Mr. Warren. How far back does it go?

Mr. Kenyon. It goes back some year's.

Indiana, Illinois, Ohio, are also great sufferers, but, as is shown by the map, the balance of the States of the Union have also suffered very materially. It is safe to assume that the losses from hog cholera during the year 1913 have been close to $\$ 100,000,000$. It wonld seem where such great economic waste was going on that entered not only into the prosperity of our agrieultural classes but into the serions problem of the cost of living that Congress would be willing to do everything in its power to help eradicate this disease. There should be cooperation between the states and the Federal Government. I want to put into the Record the figures showing the amount of money expended by the United States Department of Igriculture in the study of hog-cholera cures and also the amounts that have been expended for the eradication of the boll weevil.

The American hog has not had his day in Congress, but the enemies of boll weevil have had theirs. The prevention of the devastation of the boll weeril has been looked after as best we could. It is now time to pay some attention to the American hog. I desire to insert in the Record a statement of the moneys expended by the United States Department of I griculture in the study of hog cholera. Prior to 1887 the expenditures were not classified in detail, but I will put them in as best I can. The statement which I desire to be made a part of the Record. without reading. shows that sums amounting to about \$2.29.418.39 have been expended by the bureau from 1899 to 1913. inchusive: $\$ 89.564 .32$ was expended during the 10 -year period from 1904 to 1913 , indicating an average expenditure on hog cholera for the last 10 years of $\$ 8.956 .43 \mathrm{per}$ year. I ask that this statement be inserted in the Record without reading.

The Presiding Officte. If there be no objection, it will be so ordered. The Chair hears none.

(The statement referred to is as follows:)

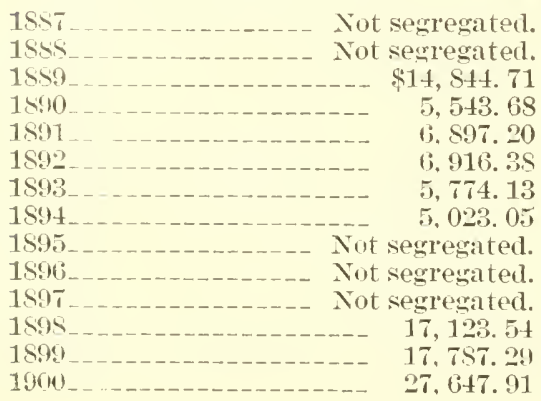

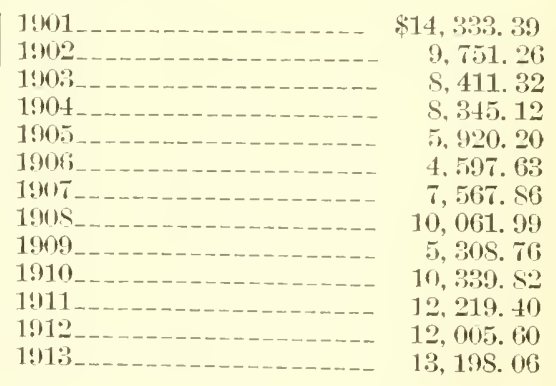


Mr. Kenron. That is what the Government has done per vear in the last 10 years to assist in blotting ont the ravages of hog cholera. That is an insignificant sum. On the other hand. Congress has appropriated year after year hundreds of thousands of dollars to purchase garden seed for free distribntion by Members of Congress. The seed purchased for this purpose hare cost this Government many more hundreds of thousands of dollars. and if the money that has been spent in garden seed had been spent for the eradication of hog cholera we would not have had the situation which to-day exists. So I am merely pleading for less " pork barrel " and more pork meat.

Mr. Jon Es. Mr. President-

The Presiding Officer. Does the Senator from Iowa yield to the Senator from Washington?

Mr. Kenton. Tes.

Mr. Jones. Can the Senator from Iowa give us any idea as to what has actually been accomplished?

Mr. Kexiox. I am going to try to do so.

Mr. Joxes. Will the Senator further on state what has been spent by each State?

Mr. Kenyon. Yes.

Mr. Jones. Very well.

Mr. Kenron. I will say to the Senator that the map hanging on the wall of the Chamber shows the amount the States have expended at serum plants and for the building of such plants.

Mr. Jones. But it does not show what has been expended on experiments and investigations to determine what ought to be done?

Mr: Kenron. No. The legislatures hare appropriated certain sums that have been used for experiments in different States.

Mr. Joves. Has the Senator any information which would enable him to tell us how much the States have actually expended?

Mr. Kenron. Yes. For the eradication of the boll weeril the Gorernment has spent in the last 10 year's $\$ 2.133 .951 .80$, while it has spent $\$ 89,564.32$ for the suppression of hog cholera. In addition to that vast amomt expended for the eradication of the boll weevil, Congress has made specific appropriations during the years from 1905 to 1908. I am not criticizing those appropriations in any way; they.went for a good purpose; I would have roted for then had I been here: but I merely desire to call the attention of the Senate to the small appropriation in comparison which has been made available in the hog-cholera fight.

The Department of Agriculture claims that in the year 1912. I think it was, the boll weevil caused a loss to the cotton crop in this country of about $\$ 20,000,000$, and a conservative estimate of the loss during the last 10 years would perhaps be $\$ 200,000.000$.

The purpose which the Senat or from Ohio and myself have in mind in presenting these matters to the Senate is because the matter is now being discussed before the Committee on Agriculture, and we thought possibly we might have as large an attendance in the Senate as before the committee, and that. in any event, we would get these matter's into the Record for thought. I want to assure the Senate-

Mr. Woris. Mr. President

The Presiding Ofricer. Does the Senator from Iowa yield to the Senator from California?

Mr. Kenron. I do. 
Mr. Works. So far as I have been able to see, the one important thing which should appeal to the Senate in dealing with this matter has not been touched by either the Senator from Ohio or the Senator from Iowa.

Mr. KenYon. I am not through; just give me an opportunity.

The Presiding Officer. Does the Senator from Iowa yield further to the Senator from California?

Mr. Inenyon. Certainly.

Mr. Works. I shall certainly give the Senator all the time he desires, so far as I am individually concerned; but there has been a great deal of money expended by the Government, according to the statement of the Senator from Iowa, and I should like to have the Senator show, if he can, what beneficial results have followed from the nse of this serum. According to a statement of the Senator from Ohio [Mr. I'omerene], the loss of hogs has increased immensely during the four years that the serum has been in use. I do not know whether the senator from Iowa has any figures or data that would cover that phase of the case.

Mr. Kenrox. I have exactly; I have a mass of data that I hesitate about using. I was going to put them into my remarks, but I hesitate about taking up the time of the senate to do so. I wish, however, to say to the Senator that there is not any question of doubt in my mind that there are two sides to the proposition of the serum treatment. In our State we have lost thousands of dollars by bad serum. This selum business, like every other business, offer's a fine field for the grafters; they have gone into it. and they have manufactured bad serum. We have had mary losses from such serums.

I am not taking the position at all that the serum treatment is absolutely and certainly a remedy, and I am not aligning myself on the side of the serum treatment nor against it. I say there is so much discussion, so much uncertainty, about the serum treatment that that in itself is an argument in favor of a large appropriation which the Seeretary of Agriculture may use in further investigating the serum treatment and its results; and I expect to put into the Record some of the figures of Dr. Stange. of my State. who has charge of the plant at Imes, showing the actual result of the use of the serum that is manufaetrured there as to varions herds. I also am going to place in the Record some letters denouncing the serum treatment in mnmeasured terms, and contending that if Congress or the seeretary of Igriculture would absolutely stop all shipments of serum it would be better, and that the disease would be sooner eradicated. 'That is one of the uncertainties of this problem. I am, however, coming to the matter's the Senator suggests in a few moments. I am glad if there is any question involved here that exeites any interest at all.

The other proposition that I laid down in commencing is the economic one in the movement, that this not only affects the agrienltural classes of this comntry, who are entitled to consideration, but it affeets the question of the high cost of living; and it is not only in the actual loss of the meat that the cost of living is affected, buit this enters into the question of the production of beef eattle. We often hear the question asked, "Why has the beef production in the agricultural States of the Middle iTest fallen off so much during recent years?" One of the prime reasons, in my judgment, is this very thing-the ravages of hog cholera. 
A man who is a practical farmer, as I am, knows that the cattle industry and the profits therein are dependent to some extent upon the raising of hogs. The hogs follow the cattle; they eat from the cattle; they are practically no expense. The hogs are the profit of the farmer in cattle raising. If the farmer is to have a profit from his cattle, it is absolutely necessary for him to have hogs to follow with the cattle. With the great devastation of the herds by cholera, it would not be profitable for the farmer to engage in the stock-raising business; or, at least, a great many farmers would feel that they could not longer run this risk, as they have been doing, and hence many of them are selling their crops instead of feeding them to cattle.

There have personally come to my attention instances where farmlcrs have lost their entire herds of hogs, amounting in some instances to three or four hundred head. The farmers were feeding those swine along with their cattle, expecting to come out even on the cattle and to make some profit on the hogs; but with those losses going on, the farmer would become a bankrupt if he continned in the cattleraising business. There would be thousands of farmers who would engage in stock raising if they could be reasonably assured that they would not lose their swine from this plague.

Now, what can Congress do? I realize that that is a very debatable question. It is the theory of those who are proposing liberal appropriations that there must be cooperation between the States and the Federal Government in eradicating the plague. There is another step that must be taken. The complaint has been made of the shipment of quack serums into the various States, which have been used by the farmers to the destruction of their herds, and it is estimated that the farmers in my State have spent hundreds of thousands of dollar's within the year for fake serums. That has been the experience of other States. I hold in my hand a little article from Fargo, N. Dak., which is as follows:

STUNG BY FAKE CHOLERA CURE-FARMERS OF NORTH DAKOTA ARE VICTIMS AND LOSE IIOGS VAL UED AT $\$ 500,000$.

\section{Fargo, N. DAK., December 30 .}

Farmers of North lakota have baid mole than $\$ 20,000$ for fake serums adrertised as pleventives of hog cholera, according to the state food commissioner, Prof. D. F. Ladd, of the state agricultural collere. Prof. Ladd estimated the loss to farmers through the death of animals from hog cholera in the last four months at more than $\$ 500,000$.

The rules of the Department of Agriculture with relation to this matter were not effective until July 1, 1913. I am inclined to think that if the rules of the Department of Agriculture were strictly cnforced and they could adopt a rule under the act that has been passed providing for an inspection of every particle of serum before it is shipped in interstate commerce, it would meet the question to some extent; but money is needed for that very inspection. If the rules of the Department of Agriculture will not bring about the desired result with relation to fake serums, then we must have a law to prevent the shipment of these serums in interstate commerce until there has been a governmental inspection or a State inspection. I shall shortly introduce a bill covering this. The serum treatment has been a free field for the grafter, and there is no doubt that the 
farmers have been deceived and robbed by fake serums. The serum treatment can not be successful if the serums are bad, and some way must be devised to carry out rigidly the rules of the Agricultural Department with reference to these serums, and the farmer must be protected against the faker and the grafter in the serum business. I do not mean to advocate the sermm treatment, but, as suggested before, I do say that the confusion concerning it is an argument in faror of a liberal appropriation, so that the Department of Agriculture may pursue its investigations along this line. I am anxious to get at the facts.

Dr. Dorset, Chief of the Biochemical Dirision of the Burean of Animal Industry, is the discoverer or inventor of hog-cholera serum. He has been assisted in this work by Dr. Chas. M. McBryde and IV. B. Niles, and others have undombtedly contributed thereto.

Dr. Dorset defines hog cholera as follows:

Hog cholera is a very contagious, highly fatal disease peculiar to swine, which callses the death of from forty to sixty millions of dollars worth of hogs annually. Hos cholera has no relation to any otler disease of man or animals. It is cansed hy a minute gelm that exists in the hlood and body Huirls of hogs sick of the disease.

I am not going into the question of germs or other medical terms with relation to hog cholera. further than to say that the gem of hog cholera is elassed with the "invisible micromeranisms," and in this respect it resembles those which bring abont a number of other disease of animals and men. notably yellow ferer. contagious pleuropnemonia, Gouth Ifrican horse sickness, and foot-and-mouth disease. Invthing which tends to lower the health of the animal may be regarded as a predisposing canse. such as improper feeding. insanitary condition of hog lots, damp or cold sleeping places. filthy watering and food troughs.

The above conditions "an not produce hog cholera, but they can aid to a considerable extent. owing to the nuhealthy condition of the hogs. However, it is necessary for a hog to contract one of the germs of cholera before it can be affected. The sick hog is the most dangerous factor in the distribution of this disease. There are many ways in which the disease can be arrierl to well herds. Dogs frequently carry the germ; in fact, this is a rery eommon way; again, it can be carried by the turkey buzzard; also, liy the common crow. I know of several instances where this bird had partaken of a meal from hogs which had died from the cholera, then carried the disease in this way into well herds on some other farm. where they chanced to light. I am also informed by reliable farmers that the disease can be carried downstream from herds which are affected above. I know of one instance where a whole herd was wiped out in this way. The disease can also be brought onto the farm by the purchase of new stock for breeding purposes. I recall such an instance, where practically the entire herd was lost from such exposure.

Of conrse, Mr. President, there is a great deal in the proposition that must rest with the farmer himself. Sanitary conditions, methods of feeding, and quarantine are matters that he should be instructed in through the agents sent out by the Department of Agriculture in their demonstration work.

After hog cholera has been prevalent on a farm, the premises should be thoroughly fumigated in order to guard against new herds 
becoming affected by reason of being placed in such pens and hog houses. A person can not be too careful in cleaning up his premises after the disease has once been stamped out, for. if great care is not exercised, it will again appear. Of course, the germ will die out in time, but it is impossible to give a stated period, as it varies in different sections of the comntry. I understand that hard, freezing weather will kill the germ, but it is not advisable to place hogs in pens previously occupied by sick hogs until three or four mont hs a fter the disease has disappeared.

The majority of cases of cholera make their appearance in the early summer and fall. In Iowa it started in rery carly in the summer last rear. and I think this has been true for several vears past, so far as Iowa and other Middle Wrestern states are concerned. It has been shown that the loss from hog cholera has been as high as 100 per cent in sonte herds, while perhaps the arerage will run from 60 to 80 per cent. In some instances the hog is worthless after having been affected with this disease. for the reason that he has become stunted. It is not best to place hogs recently recorered from hog cholera with a well herd. for in all probability the herd will become affected. sick log should be kept flom the well herd for several months, unless the well lerd has had the serum treatment. which it is claimed. will prevent the spread of the disease in the herd.

I am indebted for many of the facts with relation to hog aholera to Farmers Bulletin No. 379. of the Department of Agriculture, which is a valuable bulletin for the farmer.

I ask permission to insert at this point, without reading, a number of extracts from that bulletin which may be of interest to the farmers who may read my remarks.

The Presinixg Officer. If there is no objection, the request will be granted.

(The matter referred to is as follows:)

PREDISPOSING CALSES.

While the specific cause of hog choler: is the minnte microorganism or germ just referred to, there are maly factors which may ronker a herd more susceptible to the disease. In general, anything which tends to lower the health of the animals may be regarded as a predisposing canse. Among such predisposing factor's there may be mentioned imponer feeding, an insanitary combition of the hog lots, damin or cold sleeping places. and dirty drinking and feeding tronghs. Of comse, insanitury surrumdings and poor feed can not in thenselves produce hos cholera, but they lower the vitality of hogs to such an extent that they become comparatively easy victims of any disease-producing germs to which they are exposed.

WAYS IN WIIICII THE IIOG-CHOLERA GERM REACHES A HERD.

Althongh the conditions just mentioned undoubtedly exert considerable influence upon the relative resisting growers of hors to hog cholera, the disease can be started in a herd omly by introducing the germ which causes it. This germ is always present in the bodies of sick hogs, and is thrown off from them in large numbers in the feces and mine, thus contaninating the yards or pens in which sick hogs are kept. The most dangerous factor in sureading hog choleral is therefore the sick hog, but any agency which might serve to carry a particle of lirt from inferted yalos may be the means of starting an outbreak of the disease.

Aside from the danger of introducing infection through the hogs themselves it must be remembered that the germ of the disease, which as already stated is

S. Doc. $489,63-2+2$ 
infuitesinally suall, hay be traisponted in a minate particle of dirt on the

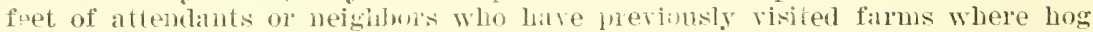
cholera exists. It may also he turred in this way by dogs and by crows and other birds. It has been claimed, and considerable proof has been brought to show it. that the disease may be carried downstream from herds which are affected above. It is therefore well to avoir placing hogs so that they will have access to streams which pass thromgl other farms. Is disoased logs are fuequently transionted by rail, it is quite possible for infection to be introluced into a farm by litter dropped from cars in transit, especially if hogs on the farm have access to the tracks.

Ifter hog cholera has visited a fam. the lots, how houses, feeding tromghs, and implements used for cleaning have naturally locome contaminated with the gelms of the alsease, and if new stock is placed ju such yints som after these were occupled hy sick logs the new hogs ale rery likely to contract the

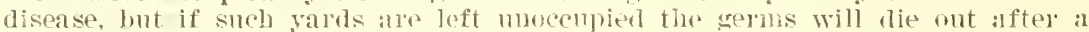
while. Cnfortumately, it is not possible to tell with reltainty just how long a time is remiled for these gems to die ont, this mooldainty being due to the

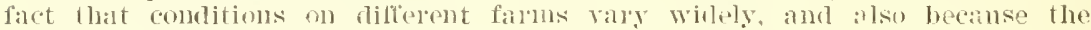
weatlue conflitions. Which have an important influnce mon the vitality of the hog-cholera germ, valy fiom time to fime and in different sections of the comutry. In view of this mncertainty it is safest to wait as loug as possible

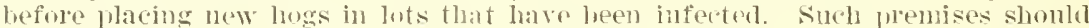
not be lestocked soomer than thee montlis after the last hog has heen removel. Pofore restocking, the premisos shold be cleaned and thorolixhly disinfected

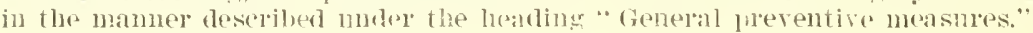

*

APPEARANCE OF A HOG AFTER DEATII FROM IIOG CIIOLERA.

In regard to the examination of loog calcasses on the farm, it nua be well to slate that while hog cholera is not commmuicable to man these is always changer of the hog being infected with other discases, such as tubermosis and anthrax, which are highly damgeroms to man, and for this reasum rare slmuld be exereised in examining carcasses of sick bogs, so as to a void a ent or sorateh m the hank, which might serve as a point for the inoculation of disease.

*

SICKNESS CAUSED BY IMPROPIE FEEDING.

Althomgh hogs are frequenty male sick by injpoper feeding, there is rarely any cause for mistaking such illness for hog cholera, the only trouble of this chalacter which is likely to give rise to confusion being in the rase of swillfed hogs. Dr. V. A. Moore has reported a disease amomer swill-ferl hogs which closely resembled hog cholera and which was dilectly traceable to the presence of powdered soaps in the slops. Some of these soaps contain a large amomut of alkali, and when mixed with the garbage nsed for feeding hogs will bring about lesions in the interual organs which are very similar to those seen in hog cholera. In most tases it will plobably not be ditlonll to, distingnish such a disease from hog cholera, especially if the mode of fexting be considered. If the illness is the to the presence of atiali in the swill, a change of food shotill result in a prompt imporrment in the condition of the animals. If this does not oceur, then, of cumse, hog cluolela or sume other germ distase should be at nines susinected.

Mr. Kenyon. Mr. President, the Department of Agriculture took up the study of hog clsolera in 1878 more in an experimental way than anything else, but that information is now obsolete in view of the discoreries of recent years. The department, however. has had a very small amount of money to use. In 1878 there was an appropriation of $\$ 10,000$ for investigating diseases of swine and also contagions diseases of donestic animals. This appropriation was renewed from year to year, and some scientists investigated the disease, but with little good result. Laboratories during the period from 1878 to 1885 were established in the department and the Bureau of Animal Industry was organized. The early work consisted, for the most 
part, in a study of the distribution, classification, and mode of transmission of swine diseases, supplemented by laboratory investigations looking to the cause of the lisease. The result of these investigations led to the suggestion of quarantine and disinfection as a preventive. While these examinations and experiments were as to domestic animals in general, in the year 18s., after an exhanstive investigation, announcement was made by the department that one of the great callses of loss among swine was a contagious lisease known as hog cholera, caused by a motile bacterium, which was named the hog-cholera bacillus. The Bureau of Animal Industry then conmenced a long series of investigations, which had for their object the development of a method of treatment of hog cholera. These investigations were based on the theory that hog-cholera bacillus was the canse of the disease, therefore that microorganism was used for the production of vaccines and serums.

Howerer, after much study it was foumd that this experiment was a failure, althongh at different times it was thought that a cure for this disease hat been discovered: but after exhanstive experiments where hopses and other animals were inoculated with hog-ehoiera bacillus in order to secure a serum for the treatment of hogs with cholera it was discorered that the serum taken from these animals rould not effect a cure, although for a time the department was very much encouraged, but after a field demonstration covering a period of some four years they ame to the conchision that the serum would rot answer the purpose for which it was intended.

The failure of these tests to cure hog cholera, and the further fact that hogs recovering from this disease were always immune thereafter. led the burean to believe that perhaps, after all, they did not fully understand the cause of the disease. At that time they came to the conclusion that in all puolmbility the hog-cholera bacilius was rot the only factor which caused this disease, so the department decided to make further experiments. In the year 190:3 there was discovered a fatal disease of swine in the State of Iowa which conld not apparently be distinguished from hog cholera. This disease was caused by an invisible microorganism, which the experts of the department claimed existed in the blood and fluids of sick hogs. It was inther discovered that this germ was so minute that it could not be found by the highest powers of the microscope to be had at that time.

When this disease was first discovered in the State of Iowa, upon craful invetigation it was fonnd that this invisible microoranism was identified with all outbreaks of hog cholera, and the department came to the conclusion that the failure of all their earlier attempts to secure an effective serum was dne to the fact that they har failed to take this invisible microorganism into account. The department spent considerable time after the discovery of this disease in trying (o) arrive at the true camse of hog cholera and the relationship of hogcholera bacillus to hog cholem. as well as to the extent of this new disease found in the State of Iowa and its relation to hog cholera. The burean carried on exhaustive investigations and considered the clisease in all its phases. These experiments were considered of vast importance, and the conchusions, in brief, are as follows:

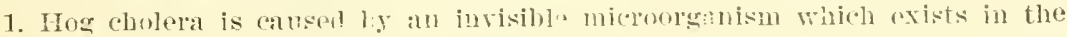

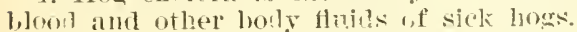

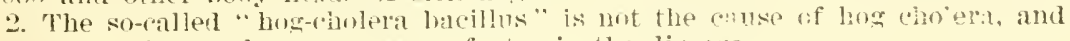
at the most is merely an aceessory fitcor in the discose. 


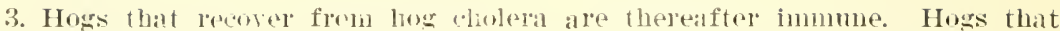
reover from artifichl infection with tles invisible virus are rendered immmme acainst the natural disease. whereas infertin witi the log-cho'erabacillus does mot comfer immmity against log cholera.

The burean deemed the ahore investigation of the utmost importance. for it opened the way for the production of efficient methorls for the treatment of the disease. and it ham also shown where the depart ment had failed in their earlier attempts to control the disease.

The investigations and experiments carried on by the burean and the conchusions reached relative to the treatment of how cholera have been confirmed by experts in this disease in foreign countries where hog cholera exists.

During the rear 190 s the burean started experiments with the view of nsing the hogs themelves as a sonree of protective sermm, and toward the cloce of the year it was demonstrated to the entire satisfaction of the burean that hoge could he protected from hog cholera by the following method:

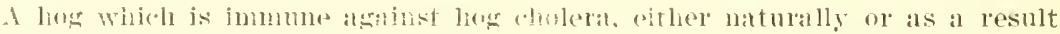

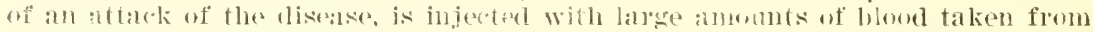

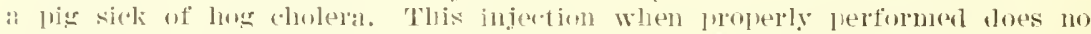

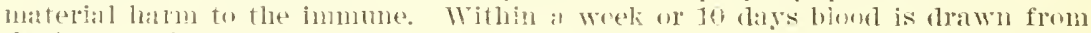

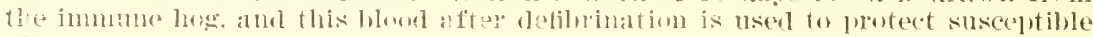
lijes:.

It was not pessible to make many terto during the rear 190.), but they were carried on during the vear 1906 and proved to the entire satisfaction of the department that they had discovered a remedy that would prevent hog cholera. It was deemed important that this discorery should be protected hy a Inited States patent, for the method had been discovered in the Govermment laboratories, and this would insure its use to all citizens of this comntry under certain restrictions latd down by the department. Therefore application was made and patent granted by the Tnited states for the mannfacture of this ser'tun to the Gorerniment or to any of its citizens without the payment of any royalty thereon.

The following facts were brought ont by these experiments:

1. When logs immume agrinst hog cholera ale injected with snitable amounts

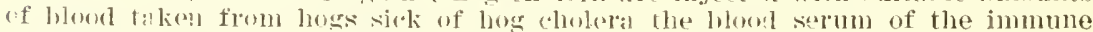
ncouimes the puwer to lontect nonimmuno hoss against an otherwise fatal ex-

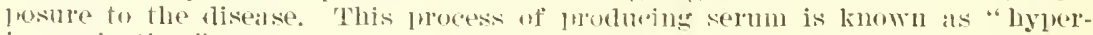
in!munization."

2. The sermu from hyperinmmnized hogs may he used to protect susceptible hogs in one of two ways: (a) The serum alowe is injecter. This confers an jmmmity lasting for three weeks to two momths. (b) The serum is injected simulanemsly with a minute amome of bloul taken from a hos sick of hog cholera!. This is known as the "simmltimeons method." and it produces an immmity which lasts for many montls, if not for life.

3. The serum is essentially a preventive. It does not cure hogs already visibly sick. lut it may le med sucessfully as a cure if aministered in the very early stages of the discase.

The (rovermment confined their experiments to hogs kept at different experimental stations up until the vear 1907 , at which time they concluded these experiments had reached such a satisfactory stage that it was deemed advisable to try field experiments: so they selected several humdred head of hogs on different farms throughout central 
Iowa for this test, and the following method was used in carrying on this work:

Class 1. Healthy beris treated fol the purpose of protection agininst hog choleria which existed on neal'by farms. In each herd il certain number of hogs were not treated, but left to serve as controls. In most of the herds in this class the disease did not appear in either the treated hors or the controls. In a few of these herds, bowerer, hog cholerat ippeared some weeks after vaccinttion among the controls, the average loss being fis per cent of the untreaten controls, while of the treated hogs in the same herd associating with the sick control animals none died.

Class 2. Herds which hat been exposed to disense through the entrance of a sick hog from a neighboring diseased herd. but at the time of treatment were ajphrently well. In these exponsed lierds 4 pel cent of the treated hogs died, while more than s! per cent of the untreated control animals sucenmbed.

Class 3. Herds in which log cholera existed at the time of treatment. In these herds the effort wis made to treat only those herds where disease had not mogressed very far, as past experience had shown that the serum was essentially a protective agent rather than a cure. As a general rule this third class of herds contained comparatively few visibly sick hogs, but yet in sufficient number to show clearly that hog cholera was present. this heing confirmed by post-mortem examination in each case. In these sick berds 13 per cent of those that receiver the serum were lost. whereas of the untreated comtrol animals 75 per cent died. The success of these pritctical tests. following the miformly good results obtained in the previous experimental work. was sufficient to show that in this new serum the department possessed a substance which conld be utilized to refuce, if not ultimitely to entirely eliminate, losses from hog cholera.

After these experiments had been earried on for some time the departn ent sent a notice of the same to the different States and requested that they send a representative to investigate the work being carried on in the State of Iowa, and also that they might become acquainted with the methods used in the manufacture and application of the serum. Some twenty-odd States took adrantage of this invitation and sent representatives to inrestigate the work being earried on. This was during the rear 1908. Fince then the department has continued its experiments relative to reducing the enst of this serum, and now have sueceeded in producing an effective serum that can be had for a cost of from 15 to 40 cents per treatment of each hog.

I desire to insert here, as a part of my remarks, a statement of the Burean of Animal Industry as to the methods of producing hogcholera serim.

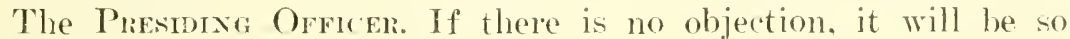
nerlered.

(The matter referred to is as follows:)

A rigorous immme bor-that is, one which has recovered from an attick of hog choleral or one which las been expmest to the disenso withont contrarting it-is treated with a linge quantity of blood from a hog sick of hog cholera. After a week or two bood is drawn from the inmume by anting off the end of the tail. After standing, the blood clot is remored and the serum or thid portion of the bloot is mixed with a weak solution of alloblie actu and tiller into sterilized lottles. We hare in this finid portion of the immmes biom the selum which will protect hogs from hige eholera. This serm is nsed in either one of two ways, namely, (1) the serum incenlation and $(2)$ the simultaneons inoculation.

These two methods of treatment are carried out as follows:

serum inoculation.-The hogs which are to be protecterl ale injected on the inside of the hind leg witli a suitable dose of the serum alone. This injection will serve to motect hogs from hug choleril frr several weeks, and in some cases for a longer time. But if the bog is not exposed to hog choleral within a fuw 
weeks aftel this trentment. the immunity whiclo is amferred by the serum will grallually lessen in rescese and the hog may again hecome susceptible. If, however, the hor is axposed to hos choler'al within a short time a for the injection of the serum, the immminty hecomes, so fal as experiments have shown, of permanent and lifelongr duration.

simulancous inoculation.- In this form of vacoination the same sermm is nsed as is emploved when the selon alone is used. Int in addition to the sermm there is injereted on the opprosite siele of the boty, in the some manner as the servm, a very small amount of blont taken from a hos sick of the cholera.

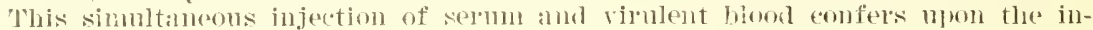
jeetefl pig a permbinent and lasting immmoty. and is therefore to be recommencled in rases of well berals whicli may not be exposed for some months aftel the treatment.

Mr. Kangon. The department has been handicapped in its work in the past years for the want of proper fumcle to carry on this work. Congress, howerel last year make an appropriation of $\$ 6.000$ for the continuation of this wolk. lout it was not suflicient. and the funds vere exhansted early in the fall, on far as Iowa was eoncerned. I realize the fact that the department was handicapped for the want. of sufficient sermu to anry on the work. and for the further reatson. as has been suggested by the cenator from (thio. that the appropliattion was not araibale intil the 1st day of .Jily, 1913. It this time the burean is in a position. if it can secme a liberal appropriation. to fight this plague and to successfully combat the disease, but it will be necessary to have a good portion of this moner made arailable for immediate nse, in order that the butiean may become properly organized.

I ask permission to insert as a part of my remarks a letter from Presitlent Pearson, of our State Igrieultural College, emphasizing the fact that a dollar early in the year is better than three or four dollans later in the summer. When the disease of hog cholera is in full force.

The Presinnx Orricer. If there is no objection. the letter may be inserted in the Record.

The letter referred to will be found in the appendix to Mr. Kenyon's remarks.

Mr. Kengon. The burean carried on experiments in the following Sitates during the year 191:) and is continuing the same at this time, namely, in Nebraska, Indiana, Missouri, and Iowa. The department has no full reports arailable relative to the work carried on in the comities of the States named. such as Inalla- Comty. Iowa: Pettis ('omity. Mo.; and Montgomery County. Ind.. and at present is unable to give a very definite statement. The department, however. is able to ascertain at this time that the losses from hog cholera in these counties have been distinctly lest than in either of the two years immediately preceding.

That bring up the question which the Senator from California [Mr. Morks] sugrested. that with this effective serum. as has been reined by him, the losses have continually increased. Even if the serum were perfectly effective. it might not be strange that the losses thould have increased, becanse it has been absolutely impossible in Ohio or in Iow: or in other sitates to manufactme this sermm in mifficient quantities to meet the demand. I was at the Iowa Agri"ultural College some two months ago, and at that time they told me that they were 13 weeks behind, and I think in the State of Olnio they are about a thomsand orders hehind all the time: so that they 
('an only treat certain numbers; and the disease is increasing sinply because of the lack of the sermm. granting that the serum is the best treatment and that it can do the work.

Mr. Joxes. Mr. President

The Pliesuma (Orforr. Does the Senator from Iowa vield to the Senatol from ITashington?

Mr. Kéryon. I do.

Mr. Joxes. Has the senator any information as to what it would cost to install a plant by which the United States Government could furnish suflicient seram to take care of the situation thronghout the country?

Mr. Kentox. No: I have not. I assmme that it would cost a great (ieal of money. I am not adrocating that; but I do feel-_

Mr. STerling. Mr. President-

The Presiding Orricer. Does the Senator from Iowa yield to the Senator from south Dakota?

Mr. Kerron. In just a moment. I do feel, however, that those engaged in the commercial business of manufacturing and shipping sermm should be under governmental inspection.

Mr. Joxes. It seems to me that that is certainly true. or else the Govermment should produce the sernm and itself send it ont. or the States.

Mr. Kenron. I think the States can produce serum under cooperation with the Goverument.

Mr. Stendica. Mr. President, will the Senator allow me to ask him al question?

The Presidng Orfickn. Does the senator from Iowa yield to the Senator from South Dakota?

Mr. Ken yon. I do.

Mi. Stencixa. The Senator may have already made the statement, but if so. I did not hear it, as to how long this serum treatment has been going on. For what length of time has there been such treatment?

Mr. Kenyon. Dr. Dorset's patent was granted. I think, some five or six years ago. I can not be absolutely accurate as to that: but I would give it as my estimate that it has been in use for some five or six years, though not in any wise to the extent that it has been used in the last two or three years. The general use of this serunt. I think, has been confined, say, to the last three years.

Mr. STEnLixa. Ought not this sermu treatnient for that length of time to have demonstrated whether or not it is a successful method of treatment?

Mr. Kexyox. Well, as Was suggested by the Senator from Ohio, there are still people who do not believe in vaceination for smallpox. There are those who are not ret satisfired as to its eflicacr. The reports I have from the Iowa A grienltural College show that the treatment has been successful: but. on the other hand, the letters which I have from Dr. Lowry, of Ottumwa. Iowa, and cthers ale to the effect that most of the hog-cholera canes me due to the sermm.

Mr. Counns. Mr. President-

The Pliesionat Oricen. Does the semator from Iowa vield to his colleague?

Mr. Kengon. I do. 
Mi. Cummss. I think if my colleague would describe, in a general way, how the serum is profluced. Senators would have a better idea of the difficulties which attend its manufacture and the expence incident to it. It is not easy to establish a plant for the production of this medicine, nor is it inexpensive to operate one.

Mr. Kexrox. I am rery glad my colleague has mate that suggestion. I have been hurrying along, because I did not feel there was. on the part of the Senate, much interest in the subject.

Mr: Surru of South Carolina. Mr. President

The Presmong Orfacer. Does the senator from lowa rield to the Senator fiom South Carolina?

Mr. Kenyon. I do.

Mr. Smitr of South Carolina. The question as to the efficacy of this treatment was raised a moment ago, when the Senator from South Dakota [Mr. Sterling] asked whether this treatment had proved a success. Some time ago I happened to be present at an interstate meeting which was attended by the former Secretary of A $\mathrm{gri}$ culture, Mr. Wilson, when that very question was asked. Ile replied that where the serum used was prepared aceording to the formula recommended by the Department of 1 griculture, and used as recommended by the department, it had proved a uniform success.

Mr. Kenron. I think rely few instances can be found where it has not been a success where that kind of serum has been nserl.

Mr. Smitri of South Carolina. I thonght force might be added to the argument made by the Senator who now has the Hoor by calling attention to that statement, coming, as it does, from perhaps the highest possible authority, because probably more of this serum has been used under his supervision than under the supervision of any other man. Secretary Wilson made that unculalified statement.

Mr. Kengon. I think that is true: and he was really a practical farmer.

In reply to the sugestion of my colleague [Mr. Cummins]-and that may answer other suggestions as to why this cerum has not worked out better--I will say that the difliculties he sugrests are true. The manufacture of hog-cholera serum is a very lifficult and a very expensive proposition. In the first place, there must be an immune log-I know this does not appeal to my friend from California, but I am going to go through with it, anyhow; that is, a hog that has been through hog cholera or that has been vaccinated and is immune. They take a cholera-infected hog and inject into the immune hog. by a rery interesting process, through a vein in the ear, the blood of the cholera-infected hog. sometimes to the amount of a anart. Then the immune hog. with the cholera-infected blood within him, is kept for ten days or two weeks. Then commences the process of cutting off portions of his tail-which he never seems to enjoyand the blood drops down into a sterilizefl bottle. That is the serum.

Mr. Woris. I have nt. T will say to the Senator, very much farored the serum treatment for man or beast.

Mr. Kinsox. Then I was not so rery buch out of the way in my st:itement.

3r. Morks. Mr. Presirent

The Presindxa Orvarem. Does the Senator from Towa rield to the Senator from California? 
Mr. Kexron. I do.

Mr. Works. The Senator from Iowa seems to intimate that I am an unbeliever and not subject to conviction. That is a mistake. I am very much interested in what the Senator from Iowa is saying. I think this is a rery interesting question and a rery inportant one. and I am looking for light on the subjert.

Mr. Kenrox. I did not mean in any way to insinuate that the Senator was net looking for light, but I feit eonfident that he did not believe in the sermm treatment, as a great many other people do not.

Mr. Warrex. May I ask the Senator a question?

The Presindra Orfacer. Does the senator from Iowa rield to the Senator from Wyoming?

Mr. Kenvox. I do.

Mr. Warrex. Is I understand, this -erum is used largely as a preventive?

Mr. Kexpon. Jes.

Mr. Warrex. To prevent the diseace lathel than to cure it?

Mr. Kinaton. Tes.

Mr. Warmex. Perhaps the Senator will wive us further information on that point.

Mr. Kexyox. I have some figures on that. After the hor is sick, if he is only slightly sick, the serum is sometimes used. lut after the disease has ohtained a virulent form it is not userl alcne. bint the virus is used, viz. the double or simmltaneons treatment.

Mr. CraRK of Wyoming. Mr. President

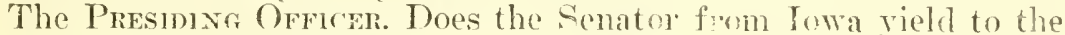
Senator from Wyoming?

Mr. Kengox. I do. Te has rather a quizrical look on his face, and I think I will vield.

Mr. Crark of Wyoming. My question is caller forth by the to me unknown method of extracting or procuring hog-cholera serum. I can imagine that a large part of the expense attendant upon the operation would he the purchase of the hogs from which this serum conld be obtained.

Mr. Kenton. T'es.

Mr. Cr.mo of Wyoming. How much of the serum can be obtained from one hog? I suppose it quits when the tail is exhansted?

Mr. Kexrox. It depends upon the size.

Mr. Clark of Myoming. It depends upon the size of the tail, does it not?

Mr. Kexrox. Oh, no: there is more to this than a mere tail. It is a very interesting tale, of conrse. [I Langhter.]

Mr. Commins. Mr. President-

The Presiding Orricer. Does the Senator from Iowa yield to his colleague?

Mr. Kexyon. I do.

Mr. Cummass. I wish my colleague would give the Senate some idea of the number of hogs that our own agricultural college has been compelled to secure in order to make this serum.

Mr. Kexyox. I can not do it accurately. Can the Senator do so?

Mr. Cummes. The number is very large. is it not?

Mr. Kengox. Oh, yes: it is a very large number. 
Mr. Cummins. I have not the number precisely in my mind, but it is a very large number, and the matter is attended with a great deal of expense.

Mr. Kengon. I would not attempt to say how many there were, but I know there wele a great many.

Some who have nsed the semum treatment are so confident about it that ther are selling hoge with a guaranty against cholera. I have seen a number of adrertisements of that kind.

I desire now to give some of the practical results of this treatment. I had not intender to do it. hut if it will excite a little interest. I am glad to do so.

I'he Govermment experimented in Pettis Comnty. Mo., Montgomery Comnty. 1li.. and l)allas (ounty. Iowa. They experimented on the nealthy hogs with the two treatinents, the -erum alone and the double or siminlanems treatment. which is different from the sermm treatment only in that the actual blood of the diseased log is also injected into the how morler treatment as well as the serum. That is a very dangerons thing. of conrse, and can be done only by experts. Their figures were as follows:

In Pettis Comnty. Mo.. the number of healthy logs experimented an with serum alone was :3.525. Of those 6 died, probably the natural result. In Montenemery County !4:3 were experimented on. of which 33 died. In Dallas Cominty none were experimented on. The average loss was eight-tentls of i per cent. With the double treatment, in Jettis Comnty they experinented on so0, and there were no losses; in Honteomery' ('oninty, :3.711. with 36 losies: in Dallas Comnty. 2.760. with 10 losies. Onit of a total of (i.971 there were 36 losses, or fivetenths of 1 per cent.

Is to diseased herds. they experimented with sermm alone in Pettis Comty on 3.801 hogs. of which 597 died. That was even after the hogs were diseased. but not. I talie it, to a very extended degree. In Montgomery County they experimented on 2.797, of which (i10 died. In I)allas Cominty they experimented on 4,959, of which 1,693 died. (Mut of 11,5.5 diseased hogs 2.910 died with the serum treatment alone, and with the double treatment, out of 7.026 hoge experimented on at the Missmuri. Indiana, and Iowa stations. there were 204 lost-less than 2.8 per cent.

I)r. Charles II. Stange, in charge of the State Biological Laboratory at Imes. Iowa, sent ne a statement as to their treatment. showing, first, the number treated with serum alone, the well and the sick, and then the number giver the simultaneous tratment.

The total number of hogs treated in healthy herds was 1.857 : the total number of hoges lost was 44 . The total inmlier of hous treated in diseased herds was 3.tico: the total number of hogs lost was 758. of which !s were sick when they were treated, or a loss of $16 ; \frac{1}{+}$ per cent, while the general rum of loss in herds where hog cholera entered has been from 60 to s.) per cent. So the practical result of this treatment in om part of the comntry has been to reduce the losis from to to sj per cent down to $16 \frac{1}{4}$ pel cent, even where the hogs were sick when treated. and to $2 \frac{1}{3}$ per cent where the hogs were treated before becoming sick.

I desire pernission to insert in the Recorrl at this point the returns of the experiments at Ames. and also the retims of the experiments by the Gorernment in Ohio. Indiana. Missouri, and Iowa. 
The Presidna Orfonr. If there is no objection, permission is granted.

(The matter referred to is as follows:)

Ilealthy hogs.

GOVERNMENT EXPERIMENTS.

\begin{tabular}{|c|c|c|}
\hline & lJogs. & Died. \\
\hline \multicolumn{3}{|l|}{ (1) SERUM ALONE. } \\
\hline ... & $\begin{array}{r}3,825 \\
943\end{array}$ & $\begin{array}{r}6 \\
33\end{array}$ \\
\hline & 4.768 & 39 \\
\hline \multicolumn{3}{|l|}{ (1) SIMULTANEOUS. } \\
\hline : & $\begin{array}{r}500 \\
3,711 \\
2,760\end{array}$ & 36 \\
\hline . & 6,971 & 36 \\
\hline
\end{tabular}

Pettis County.

\section{Pettis County}

Montgomery County.

Dallas County

Total...

Per cent loss, 0.5 .

\section{Diseased herds.}

(1) SERUM ALONE.

Pettis County

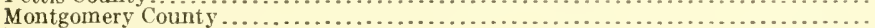

Dallas County

Total....

Per cent loss, 25.

(2) Simultaneous.

Pettis County.

Montgomery County

Dallas County

\begin{tabular}{|l|l} 
Hogs. & Died.
\end{tabular}

Total.

Per cent loss, 2.8 .

EXPERIMENTS MADE AT AMES, iOWA.

\begin{tabular}{|c|c|c|c|c|c|}
\hline \multirow{2}{*}{ Treatment. } & \multicolumn{2}{|c|}{ Healthy herd. } & \multicolumn{3}{|c|}{ Sick herd. } \\
\hline & $\begin{array}{l}\text { Numler } \\
\text { treated. }\end{array}$ & $\begin{array}{l}\text { Number } \\
\text { died. }\end{array}$ & $\begin{array}{l}\text { Number } \\
\text { treated. }\end{array}$ & $\begin{array}{c}\text { Number } \\
\text { died. }\end{array}$ & $\begin{array}{c}\text { Numler } \\
\text { sick. }\end{array}$ \\
\hline 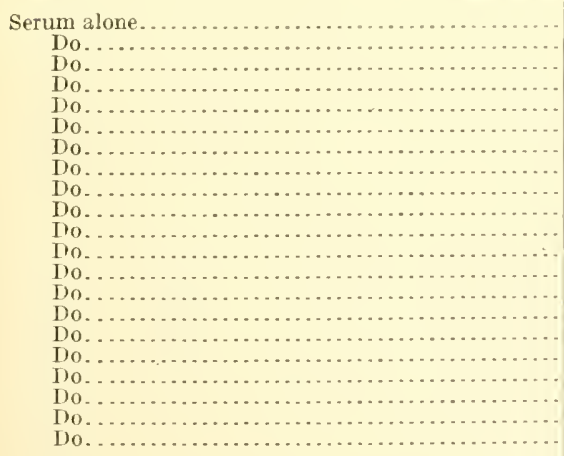 & 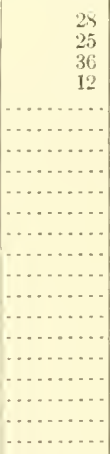 & 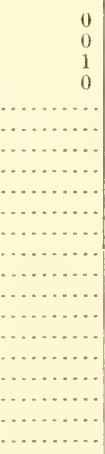 & $\begin{array}{r}80 \\
110 \\
106 \\
32 \\
6 \\
18 \\
35 \\
53 \\
133 \\
44 \\
97 \\
150 \\
104 \\
63 \\
73 \\
93 \\
61 \\
50 \\
120 \\
340 \\
154\end{array}$ & $\begin{array}{r}67 \\
15 \\
60 \\
8 \\
6 \\
0 \\
17 \\
30 \\
0 \\
30 \\
50 \\
75 \\
15 \\
7 \\
25 \\
43 \\
5 \\
0 \\
1.5 \\
20 \\
40\end{array}$ & $\begin{array}{r}60 \\
12 \\
60 \\
4 \\
6 \\
15 \\
3 \\
10 \\
1 \\
44 \\
15 \\
30 \\
16 \\
36 \\
73 \\
37 \\
50 \\
1 \\
20 \\
105 \\
30\end{array}$ \\
\hline Tot:al... & 101 & 1 & $1,92 \mathrm{~s}$ & 532 & 681 \\
\hline
\end{tabular}




\begin{tabular}{|c|c|c|c|c|c|c|}
\hline \multirow{2}{*}{ Treatment. } & \multicolumn{2}{|c|}{ Ilealthy herd. } & \multicolumn{3}{|c|}{ Diseased herd. } & \multirow{2}{*}{$\begin{array}{c}\text { Number } \\
\text { died } \\
\text { before } \\
\text { treating. }\end{array}$} \\
\hline & $\begin{array}{l}\text { Number } \\
\text { treated. }\end{array}$ & $\begin{array}{l}\text { Number } \\
\text { died. }\end{array}$ & $\begin{array}{l}\text { Number } \\
\text { treated. }\end{array}$ & $\begin{array}{l}\text { Number } \\
\text { died. }\end{array}$ & $\begin{array}{l}\text { Number } \\
\text { siek. }\end{array}$ & \\
\hline 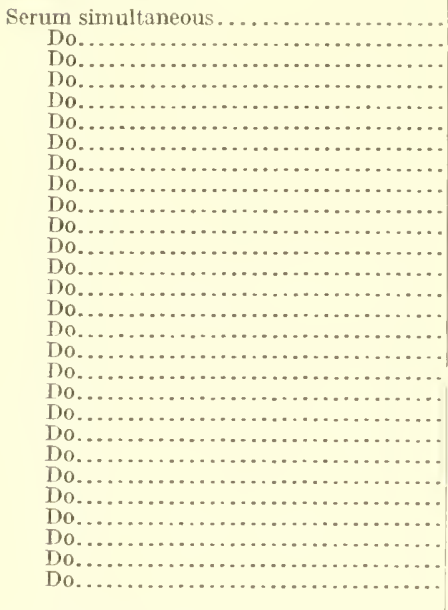 & $\begin{array}{r}177 \\
60 \\
100 \\
1 \\
52 \\
106 \\
9 \\
146 \\
115 \\
122 \\
43 \\
76 \\
40 \\
23 \\
24 \\
5 \\
101 \\
145 \\
5 t \\
155 \\
8 \\
15 \\
04 \\
75 \\
5 \\
13 \\
5 \\
70\end{array}$ & $\begin{array}{r}4 \\
0 \\
0 \\
0 \\
2 \\
1 \\
0 \\
0 \\
0 \\
16 \\
0 \\
5 \\
0 \\
0 \\
0 \\
0 \\
0 \\
0 \\
10 \\
2 \\
0 \\
0 \\
1 \\
0 \\
1 \\
0 \\
0 \\
1\end{array}$ & 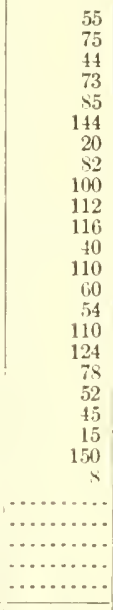 & $\begin{array}{r}14 \\
40 \\
0 \\
1 \\
2 \\
1 \\
3 \\
5 \\
0 \\
26 \\
0 \\
2 \\
4 \\
4 \\
5 \\
50 \\
17 \\
8 \\
24 \\
0 \\
0 \\
30 \\
0 \\
\ldots . . \\
\ldots \ldots \\
\ldots \ldots \\
\ldots \ldots \\
\ldots . .\end{array}$ & $\begin{array}{r}14 \\
3 \\
10 \\
1 \\
3 \\
39 \\
10 \\
5 \\
20 \\
40 \\
2 \\
3 \\
5 \\
3 \\
6 \\
65 \\
12 \\
10 \\
4 \\
15 \\
10 \\
25 \\
0 \\
\ldots . . \\
\ldots . . \\
\ldots . . \\
\cdots . . \\
. . .\end{array}$ & $\begin{array}{r}6 \\
1 \\
0 \\
0 \\
0 \\
6 \\
0 \\
2 \\
0 \\
18 \\
0 \\
0 \\
1 \\
0 \\
0 \\
7 \\
0 \\
1 \\
3 \\
0 \\
0 \\
5 \\
1 \\
\ldots \\
\ldots \\
\ldots \\
\ldots \\
\ldots\end{array}$ \\
\hline 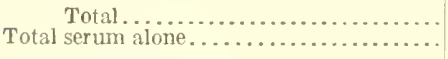 & $\begin{aligned} 1,786 \\
101\end{aligned}$ & $\begin{array}{r}43 \\
1\end{array}$ & $\begin{array}{l}1,752 \\
1,928\end{array}$ & $\begin{array}{l}236 \\
532\end{array}$ & $\begin{array}{l}305 \\
681\end{array}$ & \\
\hline Grand total. & $1, \hat{S}: \overline{1}$ & 44 & 3,680 & 758 & 956 & 51 \\
\hline
\end{tabular}

Total number of hogs treated, healthy herds, $1,25 i$

Total number of hogs lost, healthy herds, $41 ; 2 \frac{1}{3}$ per eent lost after treatment.

Total number of hogs treated in diseased herds, 3 , 6 s 0 .

Total number of logs lost in diseased herds, $750 ; 10_{1}^{1}$ per eent lost after treatment.

Total numlier of hogs siek when treatment was applied, 986 .

MIP. Kexpos. At this time there are 20 or 30 states cngaged in the distribution of hog-cholera serum to farmers. and their reports are not available. I have shown on this map the different States and the amounts ther have expended in sermm plants. I wish to insert in the Record. without reading. a list of the states having serum laboratories and a list of the States which purchase serum for distribution but do not manufacture it.

The Presidixa Offucr. If there is no oljection, it will be so ordered.

(The matter refered to is as follows:)

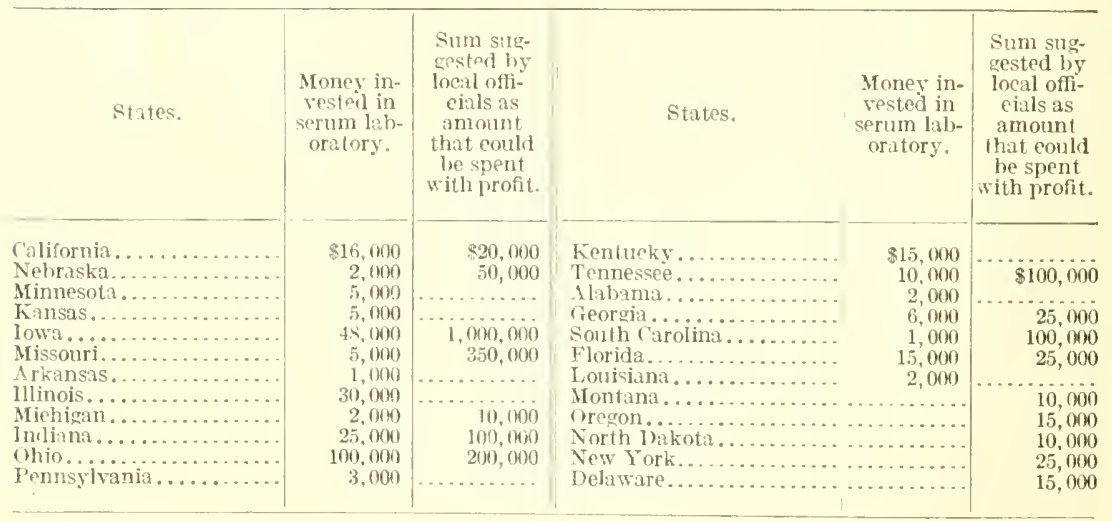


'The following States lave small investments for the manufitcture or distribution of hog-choleria serum: Delaware, a very small sum from funds of live stock sanitary bonlel. amount not known; Maryland, \$5,000; Mississipli, \$5.000; New York, no definite amount, neager fund avalible from college aproporiation; Nortl Carolina. \$1.500; North Dakota. \$3.040; Oklinoma, \$3,750; Wisconsin, initial appropriation. \$(600: South I):knta, amount not known.

'The following states do not manufacture, but lurehase sermu for distribution: Maine, amount not known: V'rmont, no definite amount; Virginia, sis, (un) to begin, subsequent fund derived from sitle of serum.

Mr. Kexrox. The Bureau of Ininal Industry has recently been adrised that the State of Missomi has increased her appropriation for the manufacture of hog-choles'a serum to \$50.000 and that the State of Idaho has appropriated the smo of \$ir.000 for the manufacture of sermm in that state.

The figures given as to the investments in the varions States show that they are awake to the conditions and are doing what they can to thrart this disease. It is probable that the rarions Gtates can manufacture the sermm necessary.

If the States can talie care of the manufacture of the sermm. and the Federal Goremment can cooperate in sending ont men to instruct in the use of the serum, to instruct as to sanitary conclitions, quarantime, and the general treatment of hog cholera, and if the regulations in relation to the mannfacture and shipment of serum are enforced, it wonld seem that this croperation of the State and Federal Governments can blot ont the disease.

I have suggested hefore that the duretion is freguently proponnded, whether the sermm treatment is good for anything. I have had letter's from farmers stating that their herds had been lost through the use of "fake" sermms, and I know of such cases. I submit some letters showing the use of the sermm in rarions States and the goot results coming therefrom: alio letters showing the bad results therefrom.

Mr. Wonks. Mr. President-

'The Presidna Orficer. Does the Senator from lowa vield to the Senator from California?

Mr. Kengon. I do.

Mr. Works. Is this sernm included?

Mr. Kexyox. What sermm does the Senator mean?

Mr. Works. I refer to the sermm that has been spoken of here as recommended by the Agriculture Department as being effective.

Mir. Kenyon. No.

Mr. Works. I wondered whether or not that was included.

Mr. Kexyox. No; that is not included. This sermm is manufactmred in different places and is shipped in interstate commerce. The bad and "fake" sermm treatment is, of course, the wrong thing, and the farmer must be certain that the treatment is right before he uses it. I feel that this shonld be covered in some way hy Govermment inspection. It is of comse. fatal to inoculate a herd with bad sermm. Toll might as well vaceinate a hmman being with barl virus.

I ask permission to insert at this point some letters from farmers and veterinary surgeons against the sermu treatment as it is only my purpose to present all sides of this question. and the discussion raging around the serum treatment is indicative of the necessity of further experiments and more work. I also wish to insert some newspaper clippings on the subject. 
The Plimsina Orfore. If there is no objection, the request will be granted.

Mr. Kexrox. Tpon reflection. I will ask later to have these inserted.

The following extract is from a letter written by the professor of veterinary science at the Linsas Agricultural College, who is in charge of hog-eholera serum production in the State of Kansas:

1 swimate that the arelage dose has been in the neighborbond of an cubic centimeters nel hog, which gives as a result aplowimately 275,000 herd of homs

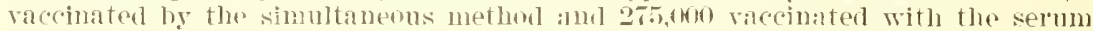
alone. I extimate that, nnder the combitions and the ganeral infection of this State. a conservative estimate of the mumber of logs silvel thromah the vaccimation would he at least half the number vacoinated, or 275.(no). This is certaiuly a conservative estimate.

That would be a saving to Kansas of orer $\$ 2000.000$.

The State veterinarian of Shio writes ar follows:

It is my opinion that at least 50 pel cent of the animils in inferted herds were sared by the serum, and I helieve, further, that this is a rery low astimate. Taling this as a basis, then. Wo hatre the following : of the tutal number of swine

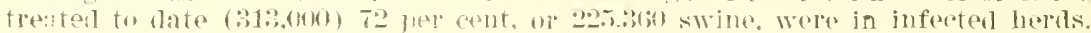
It is restsonalile to assmme that at least two-thidris of these would lave dient

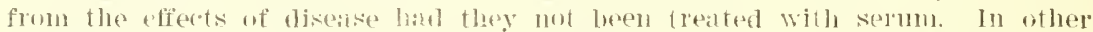

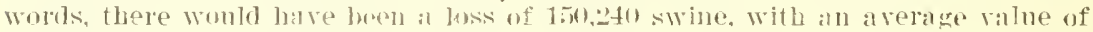

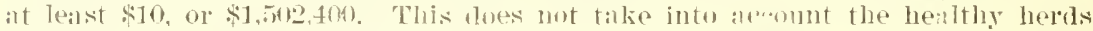
which were treated. Ino dres it take into acconnt the extral valne of the lalge jer cent of pure-breal or registerent herds.

The following is an extract from the report of the agricultural experiment station of the Igricultural College of California:

A comserwative estimate of the number of hogs silved by the antihos-cholena sorum is :

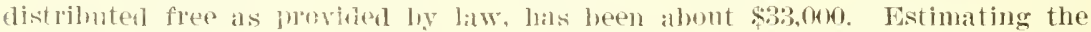

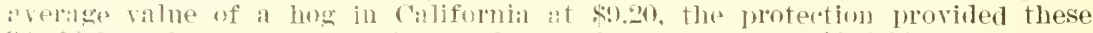

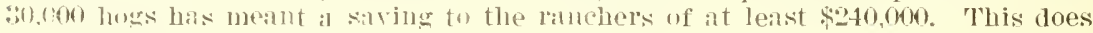
not inclube the profits resulting from the loveding and yofitable feenling of the lowst savert.

If in all cases the serum hat been used as the station recomments-that is, before the disease lats aninet entrance to the herks-then 00 per cent of all hogs ownel by these farmers womld pohably lave lived instead of only so per cent

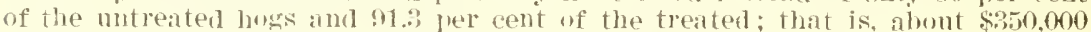
womld have been wired in aldition to the \$2 10,0 m mentioned albove.

As a representative from a great agrimltural state-the greatest in the Union-I have heen anxions not to raise hypereritical objecfions relative to varions linds of treatments, but rather to help provide the Igricultural Department with a large enomgh appropriation for them to carry on their experiments with relation to treatment of this disease that is dissipating the herds of hogs of the farmers of my State. I am doing so without adrocating any particular kind of treatment, but merely desirous to have Congress furnish the sinews of war for a fight against this element in the high eost of living. The Bnrean of Animal Industry, with a large appropriation, can extend the operations now heing carried on in Dallas County. Iowa, Pettis County. Mo, and Montiromery Comnty, Ind., as well as their experiments in Nebraska, to other comties in these states, and can also carry the work to other states in the Tnion where this disease is creating such have among swine. Further, the Burean of Animal Industry and the agents sent out can cooperate with the State agricultural enlleges of the different States and with the county agrieul- 
tural agents located throughout the country. These agents are under the control of the department and in direct touch with them. In the experiments in Dallas County, in our State, they were hampered for lack of funds.

I received a leter last year from a member of the legislature af our State, living in Dallas County, who is greatly interested in this proposition, pleading that. I secure more money for their experiments. They wore then in the midst of theil' experinents. I took up the matter with the secretary of Agriculture, and in reply he wrote as follows:

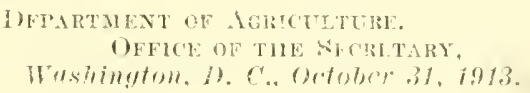

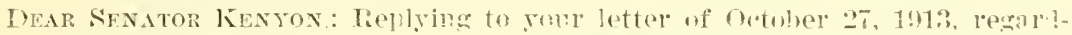

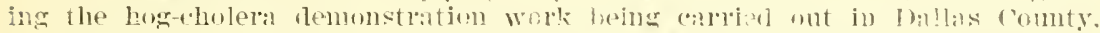

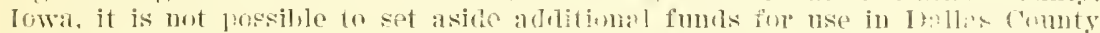

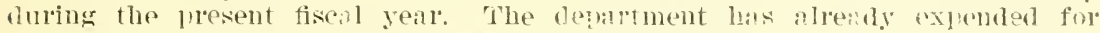

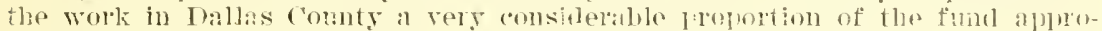

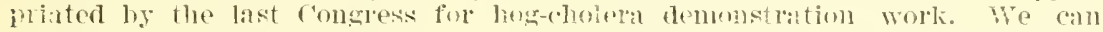
not allot anditonal finds for the Inwa exineriment withont retriment to dhe work in other states. Witli the onset of cold werther. I helieve that hos cholera will be much less prevalent. and ablitional funds at this seasen of the year would be of little aval. It miy be that if congress (leciles to (onllinne this work during the next fiscal rear. the department will neepl sume additional funds to he avalable in the spring of 1914, as it is essenti:ll fol success to herin the oradication work early in the yeall. Very sincerely.

\section{1). Hot'stos, serretary.}

As has been said by the distinguished Senator from Ohio, this money is needed soon, as it is essential for suceess to begin the elarlication work early in the year. The experiments in Dallas County could net be earried out as was desired, and as should have been done in order to attain the best results, becalise of the lack of a few thousand dellars.

I desire to place in the Record some suggestions from the Department of Igriculture as to treatment of hog cholera.

The Presidng Officen. If there is no objection. leave is granted. ('The matter referred to is as follows:)

Prevention and Treituint of hog Cholera.

GENERAL PREVENTIVE MEASURES.

All that is necessary to prevent hos cholera is to keey the germ of the disease away from the herd. It has heen shown that in the rast majority of cases this germ is transported mechanically, in the bulies of sick hoss and on the feet of men or animals includine birks. It thus foliows that the chances of an outbreak of hog choleril will be greatly lessenerl, if not completely avoided, if a Lerd is protected from these carrios of the infertion. The enforcement of a complete quarantine is, however, not luacticalle under average farm contitions. and the best that can be hoped $\mathrm{for}$ is the lossening of the olportmity for infection by placing the herc on a part of the farm that will be the least accessible to men or animals from other farms. Hog lots shomld never be located near public roads if this can be avoided. All newly purblised strack should be bept separate from the main herl for at least 30 days.

ln adation to protecting the herd by methods of quarintine, careful attention

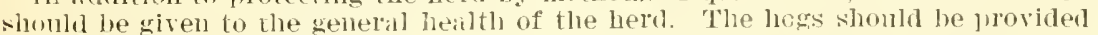
with clean. dry sleeping buces and the lots and feeding tronghs shomla be kejt clean. It is well occasionally to scatter slaked lime abont the lots and to wash 
and disinfect the troughs. Probabiy the best disinfectant for this purpose is the compound solution of cresol ( U. S. P.), which can be prepared at any drug store. One part of this should be mixed with 30 parts of waler and the troughs scrubbed with it. 'The disinfectant is then washed out of the tronghs with water.

After an outbreak of hos cholera the rarols and peus should be thoroughly cleaned, all dead hogs shouli he burned or hmiel deep with fuickime, the litter should be collected and burned, and lime scattered frecly over the mound. The sheds and hog houses should be washed thoroughly with the solution of cresol, as above described. before new stock is brought on the place. Freding troturhs that have been used by sick pigs should be burner if malde of worl, but if this is not practicalle they shonld be scrubbed rean and thoroughly soaked with the cresol solution, the latter being washed out before the trughs are used agrall.

It is possible to stirt an outbreak of log cholera in a herd by bringing hogs (II) the farm that have had the disease and have aldarently recovered. We have no definite information concerning the length of time that such lugs may lo able to commenicate the diseases to others, hut for safety's sake two or three months shmbl ho allowed to elapse after romplete recorery bofore placing such an animal with susceptible piss, and then only atter washing or dipfins in a disinfertant solution (complomul solution of cresol. 1 to $10(1)$.

In Farmers' Bulletin "-4, In. I). E. s:almon save the following formula for a molioine which was used nhany gears agu as a preventive and cure for hog cholera :

Pounds.

Wind rihareosl

sislphur.

sirlium chloride

foxlimm bicarlonate

sindimm hyposulphite

soclium sulpluate.

Antimony sulphide (blatek antimony)

Experience has shown, however, that this modicine is not to be reanred as a cme or preventive in the true sense of the words, but it is nevertheless a rery grond condition jowner. This powaler is mixed with the feerl in the proportion of a large tablesionuful to each 200 pounds weight of hogs to be treated, and slonuld not be given oftrmer than unce a day. This melicine can not be lelied ulm to prevent the occurrence of disease, except in so far as it impmes the grenclal health of the hors. Therefore, even thoming this remedy be used, strict altention must be wiven to quarantine and sanilary measures if the disease is to be warled off when in the neighborhoor.

PRENESTION ISY INOCTLATTON.

caleful and persistent attention to seneral preventive measures, such as

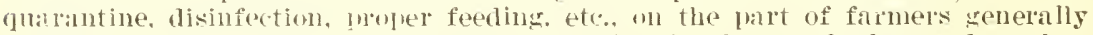
womk no donbt result in a material leduction in the vearly losses from hos clubla. and the infortince of uberving these precantions can not be wreresti-

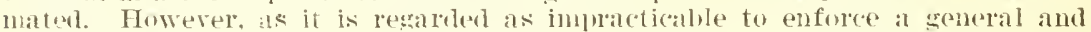
completely effective quarantine, the Bursan of Animal Industry has endeavored for a nmmber of years to tind a medicine or serum which could be used for preventing hou choleral or for coming hogs sick of that disease. It is a well-known fact that huss which have recovered from hog cholera are thereafter immune analinst that discase. The experinents of the linrean of Animal Industry resulted in the discovery that when such immunes are injected with blood from is sick hor the immune is not male sick. but as a result of this injection its hlowd acouires the power to protect other hogs from hog cholera. The details af the early experiments which served to estahlish this fact are given in Bureau ut Animal ludustry lonllein 102, which can be obtained only from sulverintend-

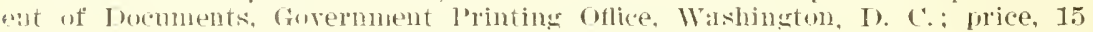
reints. Since that bulletin was issued a speat des!l of additional work has been (a) lied ont. and it has heell established beyoud question that the early observations wero colrect amb that it is entirely possible to grotect hogs if they are frated with xerum from a lmoslerly treated immme hog.

The method of molucing this selum is briefly als follows:

A vigorons immme lon - that is, one which has recorered trom an aftack of hou cholera of one which hats been exposed to the disease without contracting 
it-is treated wirl a lange qualltity of blood from a hog sick of hog cholera. Atter a weels or two blool is draw from the inmune lis colting off the end of the tail. After stanking. the blond clot is removen and the selum or fluil portion of the bluad is mixed with a weak solution of carbolic acid and filled into sterilized bottles. We have in this fluid joution of the inmmue's blood the

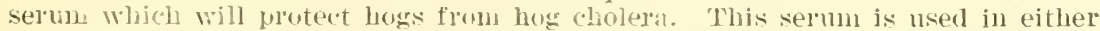

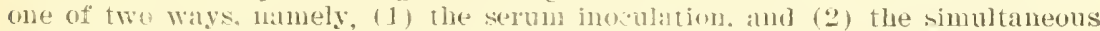
inoralation. Whese two methols of treatment are carried out as follows:

SERE IN INCELATION.

The log: which are to be protected an injected on the inside of the hind leg with a suitable dose of the sermu alome. This injection will serve to protect ings frow hog cholelal for several weels and. in some ases. for a longer time. But if the hog is not exposed to Log chon wathin a few weels after this treatuent. the immmity which is conterred by the sermm will gralually lessen in deglet and the hog may again becoung susceptible. If. howerer, the hog is exposed to hog clublera within a short tine after the injection of the selow, tile immunity becomes, so tar as experinemts lalte shown, of permanent and lifeiong dination.

From what has been sald it will he seen that the injection of the serum alone is especinily to be lecommenterl in cases where there is immediate danger of exposule. expecially when valuable hogs ale calrievl to fairs and in helds where the distalst bas alleady broliell ont but has not progressed very far. In herds of thix chatractel all of the well animals nay le treated. and evell in the case

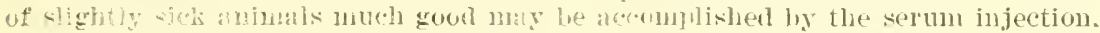

SIMLLTANEOT'S INOCULATION.

In this furu of vaccination thas stume serum is used as is employed when the swom alone is used. but in addition to the sermu there is injected on the oprosite side of the hody. in the same wannel as the sermu, al rely small anount af bool taken from a hog sick of hog choleba. This simultaneous injection of serum and virulent blond confers nlon the injected pig a permanent and lasting immunity, and is therefore to he lecommended in cases of well herds which maly not be exposed fur sone nonths after the treatment.

\section{SAFETY OF THE METH(UISS.}

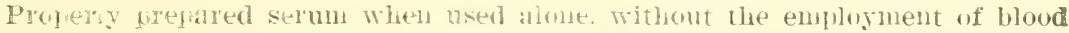

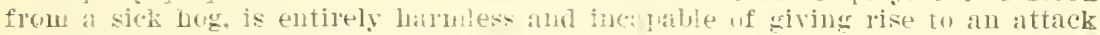
of bug cholera. Nor does this injection incerere in any way with the growth of the treated hoges.

The simntaneous inorulation, involving is it does the use of a diseaseyroduciug vilus. lequiles much nole calle when emblorer thall does the serum-

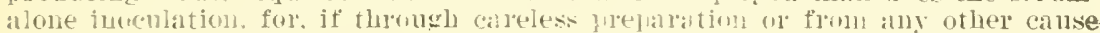

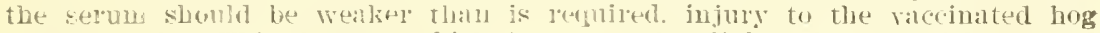
wight resuit. This dingel. which is axtremely slisht when carefully tested selum is uned. is net with in luatically all ligucessos which are now emplosed

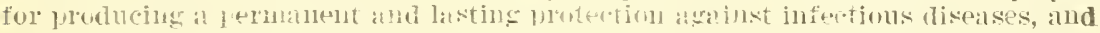
althougl it would be rely desiable to eliminate eren this slight element of

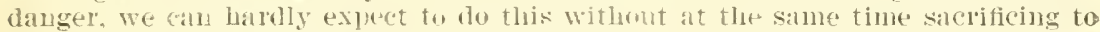
some exient the ligh degres of immunity all the frobuged protection which follows the sinultaneous wothod in its mesemt form.

Practically, in deciding which method to hos one must be sioverned latrgely

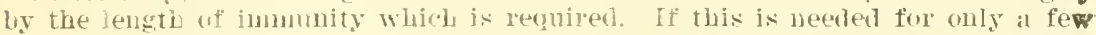
weeks a if the treatment can be rejeated at short intervals, as in the case of excertionaly valuable pure-find hogs. whele the incleased cost would not be

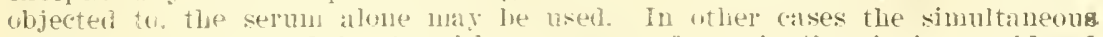

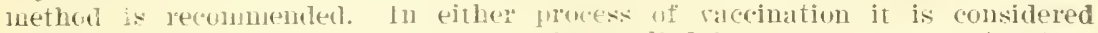

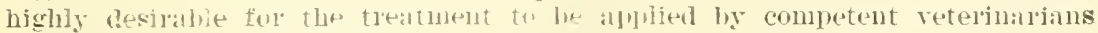
who have had slecial training in this chass of wolk. and only such skilled men shonld employ the simultanems pllores. After treatment by the simmlaneous

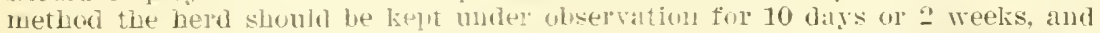

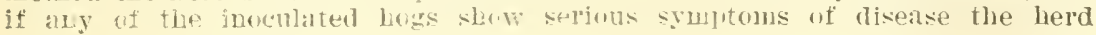

$$
\text { A. Dre. } 489,63-2-3
$$


should be immediately re-treated with the serum alone. When properly jerformed, the simultaneous inoculation does not seem to injure the hog or to interfere with its growth in any way, and if the precautions indicated above are taken it is regarded as safe enough fol matical use.

PRACTICAL TLSTS OF BOTH METHODS.

As before stated, the selmu has been tested by the Burean of Inimal Industry in an extender mamner on finlus nurler prarlical conditions, loth the sermm inoculation and the simultanems inocnlation being enuloyed at different times. In these practical expeliments a number of hogs were cenerally left nntreated, so that we might be sille that the herd actualiy biad hog chirera and also be able to determine better the action of the selmo. In these tests approximately 2,(00) hogs, located on 47 separate farms, were treated. Sime of the herds treated were alparently jelfectly well at the time, hut were in a neighborhood where hog cholel'a was prevalent. In other cases the disease was just beginning. as indicated by the sickness of one ol two animals. In other's the disease had progressed to a considerible extent, a number of the animils in the helo lreing sick at the time of treatment; and in still anotlex class of lherds the hogs hat been exposed to disease by contact with sick amimals, but hat not developed symptoms of illuess at the time of treatment. The tests were arried out under farm conditions, and aside from the serum injections no attemut was made to save the treated hogs. Uyom summarizing the results at the end of the season it was found that mole than S5 pel cent of the treated hogs had heen saved in herds that were sick at the time of treatment, while of the loogs left untreated in the same herds only 25 ler cent survived; more than 95 per cent of the treated animals were saved in the helds which had been exposed at the time of treatment. While of the untreated hogs in the sime herds only 11 ler cent survived; of the treated hoss in the leeds that did not become expmsed until after the treatment none were lost. wheleas only $\because 35$ ler cent of the numbated hogs in the sime herds survived.

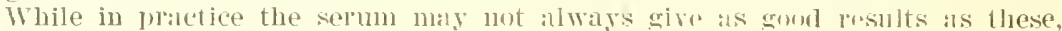
there can be no doulut that if used properly and in the early propd of an outbreak of hog cholera it will effect a rery large saring.

CONCLESION.

Siuce these results were obtained the department has blought this medhod of preventing hog cholera to the attention of the various state experiment stations and live-stock sanitary boards thronghout the anutry, and has proposed to them that they take wu this work and prepare a sam for the benefit of hom raisers, as the prepalation of sermm by the Federal Govermment on al large

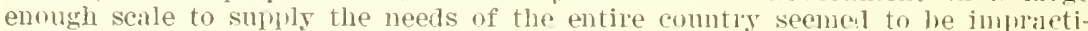
cable. As a result of this, a number of the states have taken up the work, and in practically all cases where a thoromgh test has been made they have confirmed the results obtinised by the depatment with this method. We therefore feel safe in saying that this process will prevent hog cholera, provided due cale is given to the preparation of the serum and to its application.

The serum preparation is of such a nature that it should not be undertaken by farmels themselves, hut should be under the control of traiued men who have had experience in bacteliology and who are also tholonghly filmiliar with the diseases which affect hoss. Fol these raisons no attempt has been made in this paper to describe the detals of the sorum jornction.

At the present time it is impossible to state definitely just what the cost of this serum shotild be. This will muloulsedly vary in different localities, depending upon local conditions, such as the price of hogs, the cost of feed, and similar minor considelations: l, nt it has been estimated, and this estimate has beeu confirmed by at least one of the states now conducting this work. that the sermu can be made for we cents a dose. We do not regard this as the mininum limit of cost for the serum prodnction, but latler boue that with increased knowlerge of the disease and wider experience with the selum production this estimate will be materially reduced.

Finally, it should be remembered that this selum is to be used especially as a preventive, and that little success can be expected in herds which are badly affected with hog cholera. An ealy aplolication is essential, and in the States which have taken up this work the farmers should notify the prower anthorities immediately upon theil hogs becoming ill, so that they may be treated at once. 
Inasmuch as the serum described herein is a comparatively new substance, it is not to be expected that success will always follow its use; but as it has been already definitely proved that hog choleral may be prevented with this serum, the failures, if they occur, will be causerl by local conditions or valiations in the details of sermm production, which can be corrected. Those who are interested in the subject are urged to conperate with the state anthorities who have coutrol of this work and to assist them in their efforts to roduce a reliable serum. It is only through such intelligent cooperation that we can expect to attin the final result which is aimed at, namely, the eradication of hog cholera as a serions menace to the hog-raising industry in this country.

Note.-The Enited States Department of Agriculture is not preparing antihog-cholera serum for distribution. Those who wish to obtain sernm should apply to their respective state reterinarians or agricultural colleges.

Mr. Kenyon. The Senator from Ohio [Mr. Pomerene], as he has said, has introduced a bill to appropriate $\$ 500,000$ for this work. I introduced a bill very early in the session to appropriate $\$ 750,000$ for it. Possibly $\$ 500,000$ is as much as could be expected from Congress in these times of economy. We have introduced these bills now, without waiting for the Agricultural appropriation bill, because of the very thing the Senator from Ohio has so well suggested and $I$ have so feebly suggested-that a dollar expended in the spring will be more effective than three or four dollars expended in July, and whatever is done should be done speedily.

It would seem rather a "penny-wise and pound-foolish" policy to refuse this appropriation on the ground that we must economize, and consequently permit the agricultural interests of the country to suffer. As the distinguished Senator from Ohio has suggested, we long ago reached the point in this country where the people regarded anything that detrimentally affected the agricultural interests of the country as affecting the entire people. We must be a great agricultural people or we shall not be a great people at all.

I have suggested before-and I know it is a somewhat delicate subject-that the money spent in sending out garden seeds for the last four years would have been sufficient to eradicate hog cholera in this country. It would seem more important to get rid of this scourge than it is to send out a few seeds that never were known to grow, anyhow, and are, in fact, merely political seeds, designed to reap a harrest of rotes. I am glad the present Secretary of Agriculture has recommended practically the abolition of the free-seed practice.

Mr. Jones. Mr. President

The Presiding Ofricer. Does the Senator from Iowa yield to the Senator from Washington?

Mr. Ken yon. Certainly.

Mr. Jones. I will suggest to the Senator that the present Secretary of Agriculture is not the first Secretary of Agriculture who has actually recommended it.

Mr. Kenyon. The other Secretaries did not seem to have so much power as the present one; but now, if it shall be made a party matter, to be determined in caucus, I suppose we may get rid of the practice.

Mr. Jones. I shall be very much surprised if the present Secretary has the power the Senator thinks he has in another body that we do not dare mention here. I do not think there will be any difficulty in this body, so far as that is concerned.

Mr. Kenyon. To the credit of this body be it said that they voted to strike the appropriation out of the last appropriation bill. 
Mr. Jones. Yes; and I think we were given some assurance here, were we not, when the bill was bronght in in conference. that the matter was to be taken up rather seriously at this session? That is my recollection. At all events, I hope that will be done.

Mr. Kenyox. As serionsly as any free-seed matter can be taken up.

If we must practice economy. I want to appeal to our Democratic friends-and I beliere in economy as much as they do-not to practice it on this matter. We might practice it to some extent on the franking privilege; we might practice it by not printing so many things in the Record; we might get along with a few less public buildings and rote this money for a real purpose that is for the benefit of the entire Nation-to everyone who is compelled to buy and eat meat.

I hope the bill of the senator from Ohio or some bill like it will be passed. I have no pride of opinion at all in the bill I have introduced. I shall be glad to see his bill passed. IV of our State are anxious for results. I shall cordially cooperate in any morement that will furnish liberal funds to the Government, so that it may cooperate with the States in fighting this plague.

It is not merely a question of the Northern States. If it were, I am sure our couthern friends would help us; but they are suffering likewise. We have never hesitated to vote large sims of money where there was a great public necessity. Is I have said, millions have been spent in eradicating the boll weevil and the Texas tick. In times of distress from overtlow of water we have always been generous in voting liberal appropriations. Those were more or less the South's calamities. This is partly their calamity. and to a larger extent our calamity in the North, but it is really a calamity of the American people.

'The American hog has been lescribed as the mortgage raiser, which is true. He has been compelled to go out of that business for the last few years and has been hurried to his reward entirely too fast. We are only asking now that Congress help to restore him to the proud position he once occupied-that of the mortgage raiser of the American farm and the prosperity producer of the American farmer.

Mr. Suoot. Before the Senator finishes I should like to ask him a question, with his permission.

Mr. Kenyox. Certainly.

Mr. Snoor. I have before me the bill introduced by the Senator from Ohio [Mr. Pomerene], calling for an appropriation of $\$ 500,000$ for the purpose of providing and administering remedies for hog cholera. Does the Senator believe the bill ought to provide for administering remedies for hog cholera or that it ought to provide simply the remedy itself?

Mr. Kenron. If we could provide a remedy. I should like to see it done. That is a great question.

Mr. Siroot. That is what the appropriation is asked for.

Mr. KEnYon. I think what the Senator from Ohio has in mind is the sending out of agents for demonstration work, as has been done by the Government, to instruct the farmer as to the treatment. and to instruct the State reterinarians, so that they may properly use the sermm. and matters of that kind. 
Mr. Sмоот. The bill specifically provides for administering the remedies. I thought that was rather uncalled for, because if the Government furnished the serum to each of the States the State itself, through its agencies, could administer the remedy.

Mr. Kenron. That is true, if the State officers are properly instructed by those who are familiar with the work. I will say to the Senator that in Dallas County they secured their serum from the State agricultural college. They could not secure enough of it, although finally the State agricultural college gave them the preference. The Government's special agents were there demonstrating among the farmers. They went right around among the farmers, where there were 20,000 sick hogs, showing how the serum should be used and instructing the farmers about it. That was the work the Government did there. It had general charge. That is what is intendedmerely to bring about cooperation, the Government doing part of the work, the State doing its part, and the farmer doing his part.

Mr. Warren. Mr. President

The Presiding Officen. Does the Senator from Iowa yield to the Senator from Wyoming?

Mr. KEn Yon. I do.

Mr. Whruex. I assume the idea of the Senator from Iowa in his measure is to carry this appropriation into effect something like the appropriation for the destruction of the boll weevil has been carried into eilect and executed. That is, the Gorelnment sends ont demonstrators, not only to assist in the demonstration of the remedy for the boll weevil. but to instruct the planter as to the season. how to plant the crop, and how to raise it. While I am not engaged in the cotton business. I understand that has been rery effective.

Mr. Kexrox. In other words, to make farm demonstrations.

Mr. Whriex. As I understand from the eridence that was given last year in regard to hog cholera before the Committee on Agriculture and Forestry, the remedy is a very expensive one, and must be most carefully administered; but it seems that the care of the herd, the burning of the bodies of the hogs that die, and all that, is something of which the farmers generally are igiorant, and in which they need some instruction. I assume that is what is intended by this bill, and I think the object is a worthy one.

Mr. Ponfrene, Mr. President-

The Presidng Orfickn. Does the Senator from Iowa vield to the Senator from Ohio?

Mr. Kexyon. I do.

Mr. Pomerexe. The primary object of the bill is to get Federal aid for the purpose of eradicating this disease. I take it that if the appropriation can be used in whaterer way the Agricultural Department may deem most efficacious, under any restraints that Congress in its wisdom may see fit to impose, there will not be any difficulty in determining the method in which it should be done. I think the Federal anthorities should act in conjunction with the State authorities, and I have no doubt they will do so.

Mr. Vardaman. I wish to ask the Senator from Ohio, with the permission of the Senator from Iowa, whether an appropriation ever has been made before for purposes of this character? 
Mr. Ponerene. Yes; last year $\$ 10,000$ was appropriated in an appropriation bill. The Senator from Iowa and myself tried to have the amount increased to $\$ 100,000$, and the Senate voted the increase, but in conference it was reduced to $\$ 75,000$.

Mr. Vardaman. That was to be expended under the direction of the Agricultural Department?

Mr. Ponerene. It was to be expended, as I now remember, under. the direction of the Agricultural Department.

Mr. Burton. I have the provision before me, Mr. President. It is on page 5 of the agricultural appropriation bill. After the general appropriation for inspection, quarantine work, etc., it says:

Provided, That of this sum not less than $\$ 75,000$ shall be set aside for demonstrating the best method of preventing and eradicating hog cholera.

So the appropriation was not less than $\$ 75,000$ out of a total appropriation of $\$ 654,000$.

Mr. Sноот. I will suggest to the Senator that I believe the wording of the proviso in the agricultural appropriation bill is very much better and more comprehensive than the wording of this bill. I think that covers the situation exactly.

Mr. Varduman. The Senator is not after wording. He wants money.

Mr. Kenyon. Mr. President. I have taken more time than I intended. I have a great mass of details that I have not gone into, some of which I should like to put in the record and some not. I ask permission, as an appendix to my remarks, to insert some of this matter. I shall not insert a great deal of it, but I should like to insert such as may seem proper.

The Vice President. Is there any objection? The Chair hears none, and permission is granted.

(The matter referred to is as follows:) 


\section{APPENDIX.}

AMES. IOWA, Derember 19, 1.913.

Senator WiLliam S. KẼ YoN.

Cnited states Scuate. Washingtom, D. C.

Dear Senator Kenyox: I have your kind lettel of Decembej 15 and am sorry that I bave been unable to get any more reports on herds vacciuater with our own serum. I believe, howerer. that those that are inclosed will give you a representative list. and I would not anticipate much chinge in the arerage if the list were larger. I desire to sar also that these firures are not selected in any way, but all of the reports on the use of om own serum which we have been able to rereive thus far bave been jncluded.

Yon will notice that the loss in the healthy helds treated by lue combiner? serum and virus method ras close to 2 per cent, and if two herds were ex. cluded. in which the administration was not strictly accordine to our directions. the percentage of loss after treatment would he very much less. To my mind these two columns of figures speak rolumes in favor of the treatment and also cmphasize the importance of careful snpervision of this work in the lield. You will notice also that the results of the sermu alone and the sermm-andvirus method in diseasem herds show a loss following the use of the serum-virus method. which is much smaller than by the serum-alone method.

I am taking the liberty to inclose a report male by Dr. Dorset. in chicago, in regard to the work that is being done in the states of Indiana. Missonri. and Iowa. No doulat Ior. Dorset could give yom additional valuable information.

Again referring to the inclosed table, I wish to call attention to the fact that only $16 \frac{1}{4}$ ler cent. including sick hogs. were lost in diseased herrs following application of the treationt. I believe that it is safe to estimate that without the treatment the losses in these same herds would have amomted to at least hetween 80 and 90 per cent. as the disease has heen very virulent this vain.

You mas be interested to know that I am making arrangements with the State agricuttural department to gather figures in reard to the prevalence of log choleri in the State this year, and the number of animals lost. I am sorry that we do not have these figures arailable at the jresent time. In arlition to this. the college here is making a canvass of the losses in this state, and will see that a coly giving the results of this canvass is sent you at an carly diate.

If I can be of further assistance to your. I wish you would not hesitate to write ne.

lerg truly, yours.

('. H. STANGE.

[Lnited Stataes Department of Agriculture, Bureau of Animal Industry.]

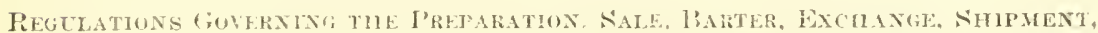

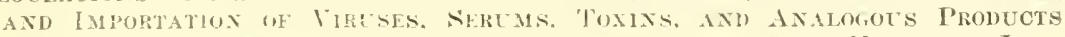
IXTENDLD GR | 1,1913 .

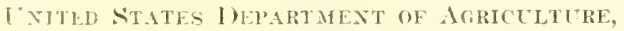

() HICE OF THE SECRETARY,

Wrashingtom, D. C.. May 31, 1913 .

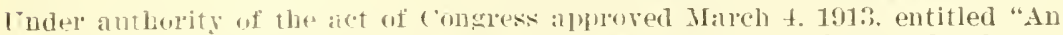
act making abroluitions for the belaltume of Acriculture for the fiscal year ending June 30. $1914^{*}$ (37 Stat. s:12). the following regulatjons are hereby

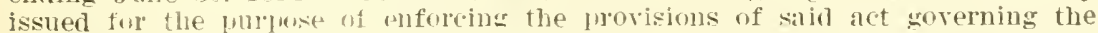
preparation. sale, barter. Pxehanes. shimnent, and importation of viruses.

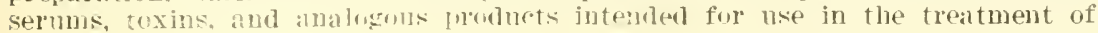




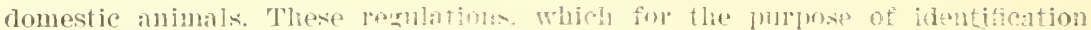

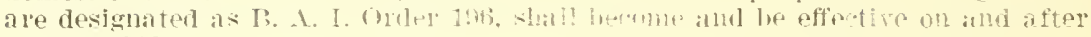
July 1, 191:?.

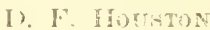

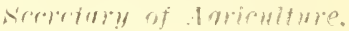

I:BTITITHN 1 .

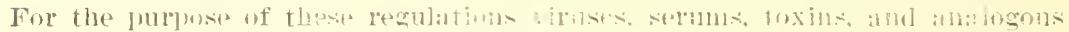

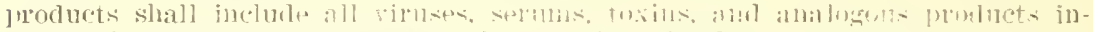

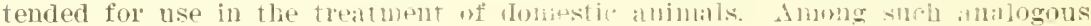

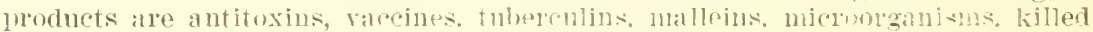

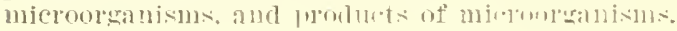

$$
\text { RF, ILATIUX } \because .
$$

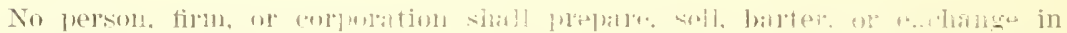

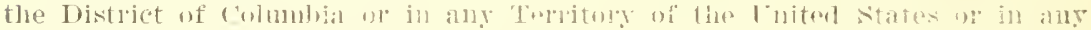

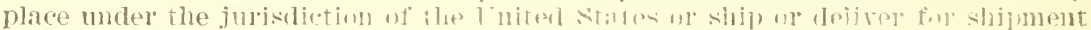

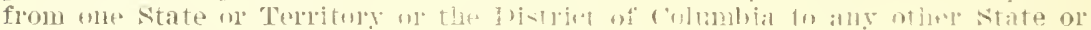

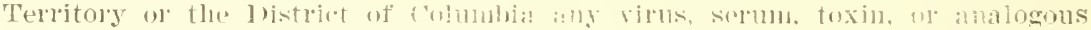

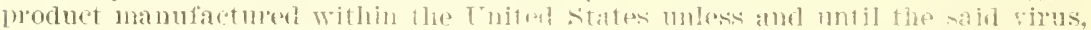

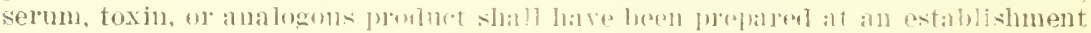

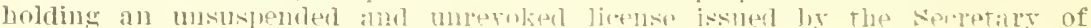
Agriculture.

$$
\text { RLGI'1..1T10. : : }
$$

Each estallishment in the [nitul states al which any rilus, sernm, toxim, or analogous product is juejared shall nlake application in writing to the Secretary of Agriculture for a license. When one proprietor conducts more than one estalblishment a sepalate applicatin shall lo mare for a licellse for each establishment. Blank forms of application will be funislued upon request addressed to the Burean of Animal Ininstry, Washington, I). C.

\section{BEGTLLATION 4 .}

Section 1. A license will unt be issued muless the condition of the establishment and the muthols of preparation are such as reasonably to insure that the product will accomplish the oljects for which it is intenrled, and that such product is not wortiless, contaminated, dangerons, or hamuful.

SEc. 2. A license will be issuel only after inspection of the establishment by a duly anthorized nfficer, agent, or euployee of the Pureau of Animal Industry has shown that the condition and ermipment of the establishment and the methous of preparation ale in conformity witl these regulations.

\section{PEITI.ATION \%.}

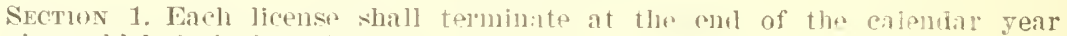
during wlich it is issued.

SEc. 2. A license slall be rejsined only after inspertion of the astablisiment by a duly authorized officer, acent. or cmploser of the linlean of Animal Industr?y?

SEc. 3. A license will not be issued for the preparation of any virus, serum, toxin, or amalogous product if adrertised so as to mislead or deceive the purchaser or if the package or container in which the same is intended to bo sold, bartered, exchanged, or shipjed bears or coutains any statement, dosign, or device which is false or misleading in any particular.

\section{REGULATION 6 .}

Licenses shall be in the following form:

Tnited States Teterinary License No. -

Washington, I), C., - - 13 -

This is to certify that, pmrsuant to the terms of the act of congress approved March 4, 1913 ( 37 Stat.. S:32), goveluing the preparation, sale, harter, exchange, shipment, and importation of viruses, serums, toxims, and analogous prodncts 
intended for use in the treatment of domestic animals, licensed to maintain at - - Street, city or town of is hereby an establishment for the preparation of __- during the calendar year 19-.

This license is subject to suspension or revocation if the licensee violates or fails to comply with any provision of said act aploroved March 4, 1912, or of the regulations made thereunder.

[L. S.]

Countersigned :

Secretary of Agriculture.

Chicf Bureau of Animal Industry.

\section{REGULATION 7.}

SECTION 1. Fach separate container of virus, serum, toxin, or analogous prod. uct prepared, sold, bartered, exchanged, shipper, or delirered for shipment shal? bear the true name of the product and the license number assigned by the de. partment, in the following manner: "U. S. Vetelinary License No. - , or an abbreviation thereof authorized by the Bureau of Animal Industry.

SEc. 2. Each separate container of virus, serum, toxin, or aualogous prodnet shall bear a serial number aflixed by the licensee for identification of the prod. uct with the records of preparation thereof. Each container shall also beal the "retuln date."

\section{REGUTATION \&}

A license will he smspended or revokol (1) if it aluonrs that tho comstruction of the establishment licensed is lefective. of if the establishment is improperly conducter ; $\{2$ ) if the methors of preparation are farlty, or if the prodnets contain impurities or lack potency: (3) if the molucts are adrertised or labelet so as to mislean or deceive the jurchaser in any lanticular: (4) if the license is usel to fincilitate or effect the preparation. sale, larter. exchange. or shipment of any worthless. contaminated, dangerous, or hamful virus, sermu, toxin, or analogous product: or $(5)$ if the licensee violates or fills to comply with auy provision of sild act alprored March 4, 1913, or of the regulations uate thereunder.

\section{REGULATION 9.}

SECTION 1. Each importer of any virus, sermm, toxim. or analogous product shall make applioation in writing to the socutory of 1 griculture for a permit. The application shall specify tle port or ports of entry at which the importes articles will be cleared throngh the customs. Tilank forms of application will he furnished mon request addressed to the Pureau of Animal Industry, Washington, D. C.

SEC. 2. Fach apulieation for a permit slall be accompunied by the affidavit of the actual manufacturer, produced before an American comsular officer, stating that the virus, selum, toxin, or analogons product mentioner is not wortlless, contaminated, dangerons, or harmfinl whether the product was derived from animals: and if so lerived, that such animals have not been exposed to any infections or contagions disease. except as may be essential in the preparation of the proluct and as specified in the affiravit.

SEc. 3. Fardh apllivation for a permit shall he accompanied by the written consent of the actul minnfuctmer that properly accledited oflicers, agents, and emplofees of the Trepurtment of Agriculture shall have the privilege of inspectjug, withont previons notification. all parts of the establishment at which such virus, selum, toxin. or analogous product is prepared, and all processes of preparation of such products. at such times as may be demanded liy the aforesaid oflicers, agents, or employees.

SEc. 4. Earh permit shall terminate at the end of the calendar year during which it is issued.

REGULATION 10.

Permits shill be in the following form:

United States Veterinary Permit No. -

WASHINGTON, D. C., —, 19 -

This is to certify that pursuant to the terms of the act of Congress approved March 4, 1913 (37 Stat., \$32), governing the preparation, sale, barter, exchange, 
shipment, and importation of viruses, serums, toxins, and analogous products intended for use in the treatment of domestic animals, —_ of —_ - State of is hereby authorized, so far as the jurisdiction of the Department of Agriculture is concerned. to import ——, manufactured bs _ _ of - into the United States through the port of —_ during the calendar year 19-.

This permit is subject to suspension or revocation if the permittee violates or fails to comply with any provision of the said act approved March 4, 1913, or of the regulations made thereunder.

$$
\text { [L. S.] }
$$

romtersigned :

Secretary of Agrieuiture.

\section{Chief Bureau of Animal Industry.}

The Bureau of Animal Industry shall give pronint notice of the issue of each permit to collecturs of customs at the ports of entry named therein.

REGTLATION 11.

SECTION 1. Fach separate container of virus, serum, toxin. or analogous product imported shall bear the true name of the product and the permit number assigned by the department, in the following manner: "U. S. Veterinary Permit No. _- " or an abbreviation thereof anthorized by the Bureau of Animal Industry.

SEC. 2. Wuch separate container of rirus, sermm, toxin, or analogons product imported shall bear a serial number affixed by the manufacturer for identification of the product, with the records of preparation thereof. Each container shall also bear the "return date."

SEC. 3. A permit will not be issued for the importation of any virus, sernm, toxin. or analogous product if adrertised so as to mislear or deceive the purchaser or if the package or container in which the same is intended to be sold, bartered. exchanged, shipped. or imported bears or contains any statement, design. or derice which is false or misleading in any particular.

REGITATION 12 .

Purnits will be suspended or revoked (1) if it appers that the construction of the establishment in which the prolucts are prepared is defective or if the establisliment is improperly conducted: (2) if the methods of preparation are faulty or if the products contain impurities or lack potency; (3) if the products are advertised or labeled $s$ as to mislead or deceive the purchaser in any particular: (4) if the permit is used to facilitate or effect the importation of any wortliless, contaminated, dangerous, or hamful virus. serum, toxin, or andogons product: or (5) if the permitter violates or fails to comply with any jorovision of said act approved March 4, 1913, or of the regulations made thereuniler.

\section{REGILATION 1:.}

A 15 officer', agent, or employee of the Department of Agriculture, duly authorized for the pmrpose, shall be permitted to enter any establishment licensed under these regulations at any hour during the daytime or nighttime, and such duly authorized officer, agent, or enployee shall be permitted to inspect, without previous notification, the entire premises of the establishment, including all compartments and buildings, and all equipment. such as chemicals. instruments. aplaratus, etc., as well as the methous used in the preparation, inndlig. and distribution of virus, serum, toxin, or analogous product.

\section{REGULATION 14}

No grinking or mixing machiners, molds, instruments, tables, or other apparatus which come in contact with virulent or attenuated microorganisms or toxins shall be used in the preparation of other forms of biological products.

BEGTLATION 15 .

Al: equlpment, containers, maclinery, instruments, and other apparatus used in the freparation of viruses. selums, toxins, or analogons products shall be thoroughly sterilizerl before use hy live steam at a temperature of at least 120 
degrees Centigrade for not less than half an hour or exposed to dry heat of at least 160 degrees Centigrade for at least one hour. If for any leason such sterilization can not be applied, then a process known to be equally efficacions in destroying microorganisms and their spores may be substituted.

REGITLATION 16 .

Permanent detailed records of the methods of freparition of viruses, sermms, toxins, and analogons products, including somrces of lucterial cultures or viruses used, virulence of such coultures or viruses, methods of testing the lumity and potency of the product. together with the methods of dreservation, sliall be kept by each licensed establishment.

\section{REGULATION 17.}

Section 1. The stables or other premises nserl fur experiment animals in the production or testing of viruses, serums, toxius, or analogous products shall be properly rentilated and lighted, appropriately drained and guttered, and kept in good sanitury condition. Animals infected with or exposed to any infectious, contagious, or commmnicable disease shall be properly serregated, and all instruments, containers, and other appalatus shall lie thorouglily cleaned and sterilized before use. Establishments shall he so located as to avoid the siread of disease. and suitable arrangements shall be mafle for the disposal of all refuse.

SEc. 2. Tiruses, serums, toxins, and amalogoms products sluall be prepared, handled, and distributed with due sanitary precautions.

\section{RETULATION 18.}

When the preparation of viruses, sermms, toxins, and anilogons products las been completed, said products shall be stored iu a cold chamber or refrigerator for preservation until such time as they are removed from the premises. All dealers in the District of Columbia or any Territory or any place under the jurisdiction of the United states shall keep such prorlucts nuder refrigeration until sold or otherwise disposed of.

REGULATION 19.

SECTION 1. Samples of vinuses, serums, toxins, and analogous products shall be collected by authorized officers, agents, or employees of the Department of Agriculture.

SEc. 2. Samples may be purchased in the open market, and the marks, brands, or tags upon the package or wrapper thereof shall be notes. The collector sluall note the names of the vendor and the agent of the rendor who marle the sale, together with the date of purchase. The collector shall purchise representative samples.

SEc. 3. All samples or parts of samples shall be sealed liy the collector all marked with identifying marks.

\section{REGULATION 20.}

The immunity unit for measuring the strengtl af tetanms antitoxins shall be 10 times the least quantity of antitetanic serum necessary to save the life of a 350-gram guinea pig for 96 hours against the official test dose of the standarl toxin furnished by the Hsgienic Laboratory of the Inited states Public IIealth Service.

The number of immunity units recommended for the grevention of tetunns in a horse shall be at least 500 units.

\section{REGULATION 21.}

SEction 1. Licenses or permits may be suspended or revoked after opportunity for hearing has been granted to the licensee or importer at times and places designated by the Secretars of Agriculture. All hearings shall be private and confined to questions of fact. The parties interested may appear in person or by attornes, and may submit oral or written eridence on the questions of fact involved. 
SEC. 2. If, after opportunity for hearing has been grianted, it appears that a licensee or permittee has violated or failed to comply with any provision of said act approved March 4, 1913, or of the regulations made theremder, the license or permit may be suspended or reroked.

IAW UNDER WIICII TITE FOREGOING REGT1.ATIONS ARE MADE.

Fxiract from "In act makisg appropriations for the Department of Agriculture for the fiseal year ending June 30, 1914," approved Mar. 4, 1913 (37 Stat., 832).]

That from and after July 1, 191:, it sla!l be mulanful for ans prerson, firm. or corporation to prepalre, sell, barter, or exchange in the District of Colmubia. or in the Territories, or in any nace male: the jurishlion of the Tuited states, or to ship or (leliver for shiment from one state or Territory, or the pistrict of columbia to any other state or Teritory of the District of colmulia, any wothless. contaminated. dangerous, ow hamful rims, selum, toxin, or amalogons product jutended for nse in the treatment of fomestic animals, and no person, firm, or corporation slall prepare. sell, bartel, exchange, or ship as aforesaid any vims, sermm, toxin, or analogons product mannfacturel within the Fnited states and inteluted for use in the treitment of domestic animals, muless and mutil the said ripus, sermul, toxin, ol analogus juoduct sluall have been prepared, undor and in compliance with resulations moseribed by the seoretary of Inicultüe, at an establishment loldins an unsuspended and mmeroked jirense issued hy the secrestaly of Agricultule as heleinafter anthorizer. That the importation into the loited states, withont a permit foum the suepetary

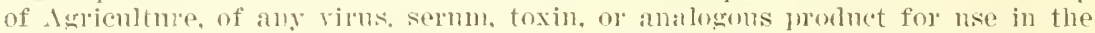
troatment of domestio animals, and the importation of am worthless, con-

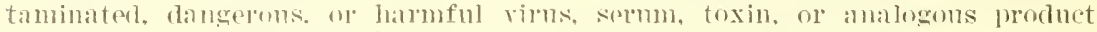
for nse in the troitment of domestic aninals, ane loreby probibiter. The Secretaty of igrienltule is herely anthorized to catuse the Bimpan of Animal Industry to examine amb inspert ali virnses, sernms. toxins, and analugons products, for nse in the treatment of domestic animals, whicli are leing imported or offeres for importatim into the rnited states, to determine whether such viruses, serums, toxins, and analogous probucts ale worthiess, rontaminated,

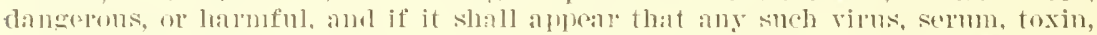

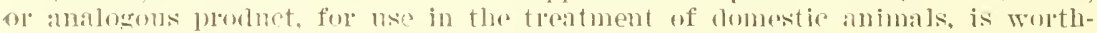

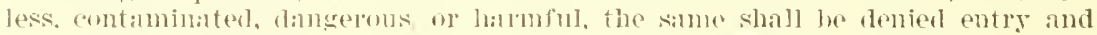
shall be destroyed or retumus at the expense of the owner ol importer. "That the Serretary of Isrienltme be, and herely is, anthorized to make and pro-

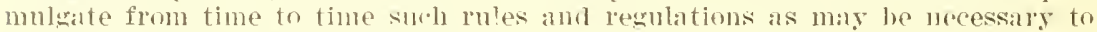

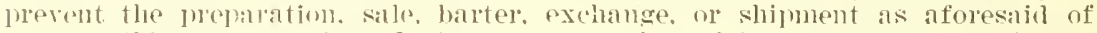
any worthless, contaminsted, damgerons, or hamful vints. sernum, toxin. or anilowoms probluct for use in the treatment of domestio amimals, and to issue, suspend, and revolie licenses for the maintenince of establishnents for the preparation of virnses, sermms. toxins, and analogoms profucts, for use in the treatment of domestic animals, intended for sile. barter, excluange, or shipment as aforesaid. The sporetary of Igrionlure is herely anthorizel to issue permits for the importation into the Inited states of virnses, sermms, toxins, and foralogoms jublucts for uss in the treatment of domestie animals, which are not wortluess, (ontamiuaterl, damgerous, or liamufu?. All licenses issued muler antlority of this act to establishments whele such viruses, sermms, toxins, or analogons prolnots are mepareyl for sile, barter, exchance, or shipment as aforesaid, shall be issued on condition that the liconses sluall permit the inspection of snch establishments and of such products ant their preparation; and the Secretary of Igriculture may suspend or revolie any permit or liconse

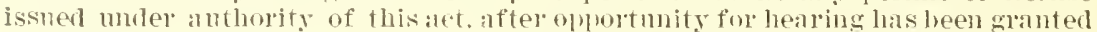
the licensee or importer, when the secretary of Isriculture is satisfiel that such license or germit is being nsed to facilitate or effect the preparation, sale, barter, exchange, or shimment as aforesaid, or the importation into the Tniter States of any worthless, contaminater, dangerous, or harmful virus, sermm, toxin. or analosons probuct for use in the treatment of domestic animals. Thit any oflicer, agent, ol employee of the Department of Arricultme duly anthorized by the secretary of Agriculture for the pmrpose may, at any homr during the daytime or nighttime, enter and inspect any establishment licensed under this ate where any vilus, serum. toxin, or analogous product for use in the treatment of domestic animals is prepared for sale. larter. exchance, or shipment as aforesald. That any person, firm, or corporation who sluall violate 
any of the provisions of this act shall be deemed guilty of a misclemeanor, and shall, upon conviction, be punished by a fine of not excecding $\$ 1,000$ or by imprisomment not exceeding one rear, or by both such fine and imprisomment, in the discrimination of the court.

Hon. W. S. Kengox. Znited states Semute.

DFPARTMENT OF AGRCLLTTRE,

OFFICE OF THE SECRETARY,

Washineton, D. C. Derember 16.1913.

DEAR SENATOR KENYON: I beg to acknowledge receipt of your letter of December 6. 1913, in which you suggest the preparation hy some of the experts in the department of a pamplilet of instructions to farmers reliting to hog cholera.

It is believed that good results will be accomplished by issuing a separate publication dealing especially with methous of preventing the s]read of hog cholera, and we have had in mind for some time the issuance of a pamphlet of this nature. The work of jreparing the pamphlet will be begm immeliately, and it is expected that it will he ready for distribution in the comrse of a month. Ol' so.

We now have a Farmers bulletin which reals with the subject of hog cholera in a pojulal was, a coly of which I am inclosing herewith.

Very truly, yours.

B. 'T'. GALLOWAY, Acting secretary.

First National Bank,

Hon. Whllam S. KEnYon,

Tnited states Senate. Washingtron, D.C.

Ir Dear SENATor: We are very much pleased to lealln that you are going to press consideration of the question of Federal cooperation in the stamping out of hog cholera. 'The losses from this disease in this section have been very great this fall, and yet they would have been vastly greatel but for the sermu we were able to obtain. When serum could be had the herds were silved in large part, Our greatest trouble was not obtaining the serum. The details of this are more fully set forth in the inclosed memorandum prepared by G. I. Bliss, our comnty agriculturist. Our scott County organization recently issued the inclosed bulletin on this subject, and I an sure you will be intorested in the good that was done with the selum treatment.

I thank you for what you say regarding my testimony before the Banking and Currency Committee. This appears in jart 27 of the printed hearings, and the amendments suggested at that time have been practically mamimously alpluoved by the "country" national banks in I"w?

With kindest regards, we ale.

Very truly. sours.

A. F. IHWSON. President.

DArExpoRt, IOWA. OCtober 27, 1913.

Hom. 1. H. ThWsox, Darenport. Ioxa.

DEAR Mr. DAwson: I was much interested in the letter which you sluowed me from senatim Kenton to the effect that he will introduce a lill calling for an apluppriation of $\$ 1,000,000$ to tight hog cluolera.

We batre been serionsly handicalner here all season hy on inability to secure reliable serum. On several occasims I have haßl men with sick lerols wating on me as long as fom or five days at a time, and I know jositively mamy herds which comld have been saved had we had good sermm to frise them wholl theil' owners first aprlied for it.

The whole problem of the treatment of pigs for choleral is an uncertilin one and will be more or less msatisfactory as fong as we have to dejend on private concerus for the sumply of sermm. due to the fact that the temptation to put it on the market even though a little weak and get the money from it is likely to prove stronger than human nature on the average catn stamcl. 
We have a good law in this state at the present time in regard to the strength and eleanliness of sermm. but it is nearly impossible to enforce this law and convict firms guilty of selling weak sermm because it is so difficult to prore thit the serum was weak at the time it was sent from the factory. Another provision of the law, which is an excellent one, requires that serum be sent directly to the farmer who is going to have his hogs treated, who will pay for it at the express oftice when he takes it away. This law prevents overcharging to a large extent on the part of the reterinarian and takes the handling of the serum entirely out of his hands. This provision, however, it has been impossible to cnforee this season because of the fact that an orler put in for serum one day with any of our private firms would simply mean a telegram stating that it could not be sent at any time within three or four weeks. Hence it was absolutely necessary, in orler to treat sick hogs when thes should be treated, for a veterinatian to have a supply of serum on hand realy for immediate action.

Just as soon as the State or the United states Goremment can furnish reliable serum at a morlerate cost to erery famer immediately mou his demand the los-choler:t jroblem will rery largely be solved. We will not have these had results to record and it will then be eomparatively eass to couvince men of the value of the serum treatment.

While the State of Iowa, throngh the sermm laboratory, has done excellent work this season and put out a large amonnt of serum, if has been utterly unable to cope with the situation, and the amount of sermm put out has been absolutely insignificant as compred with the amomnt needed in the State. To my linowlerge there has been no time since the sermm laboratory was established that one conld seeure serum within three to four weeks after ordering.

I wish to express mrself as rery strongly in faror of this bill which Senator Kenyon proposes to introduce. I think it is deplorable that the State of Iowa has not taken more rigorons action in the past to prevent the enormous losses which have been sustainet. Each rear during the past three these losses have aggregated millions of dollars, and could hare been very largely prevented if we had been able to secure an alequate supply of reliable serum.

Sincelely, yours,

\author{
G. R. BLISS, \\ Agent Lnited States Department of Agriculture \\ and County Agriculturist.
}

Better Fards-Better Crops-Better Homes-Scott County Farm InproveMent Lejgue- - Uxited states Departant of Agriculture, Iowa State College, and scoti Countr Farm Improvement langue Cooperating-G. R. Bliss, County Agriculturist.

REPORT ON SERUMI FOR HIOG CIIOLERA.

The serum treatment will save your hogs- The offer three lines of proof.

First. The Linited states Department of Agrieulture and practieally every State in the Union has declared its value by the appropriations of Congress and the State legislatures, and by the bulletins of the Various State agricultural and experiment stations.

Second. We have kept close watch on nearly 200 herds treated this season, the majority of which have been saved. Notwithstanding reports to the contrary, results in general have been good, and we can take the farmer who doubts to herd after herd where the choler; has been checked with little loss.

Third. We have placed well pigs which never had choiera but were given the double treatment in herds where cholera was raging and left them for several weeks without one of them becoming sick.

Last fall one such pig was pliced in the sick herd of Charles Kruse. On January 1 three snch pigs were taken from the Iowana Farms and placed in the herds of J. T. Hansen, Walter Koch, and Rudolph Koch. About August 1 three such pigs were taken from the farm of C. W. Lan and placed in the herds of William Murray, Carl Sehaefer, and Henry Herman. About September 1 one such picr wats taken from the herd of Lewis Sticher and placed in that of William Haines.

We have tested the serum treatment from erery standpoint and found it to be the only sure preventive of the hog cholera.

We want to emphasize the following points: 
1. Practically all the contagions tisease among hogs in Scott County is hog cholera in some of its forms, valying from the acute or quick form to the chronic or slow form.

2. No curc for hog cholera has ever been fomm, and there is only one positive preventive-the serum treatment.

3. Some farmers may think they know how to keep hog cholera from theil premises for years by certain methods of feeding, breeding, disinfecting. or sinutation, but we have seen dozens of such men finally overtaken by the disease. There is not any medicine or precantion of any kind, except the serum treatment, which can be relied upon. The cholera gelm is no respecter of porsons or methods.

Losses in herds where hog-cholera specifics were uscd.

\begin{tabular}{|c|c|c|c|}
\hline Nanle. & Address. & $\begin{array}{l}\text { Number } \\
\text { in herd. }\end{array}$ & $\begin{array}{l}\text { Number } \\
\text { saved. }\end{array}$ \\
\hline 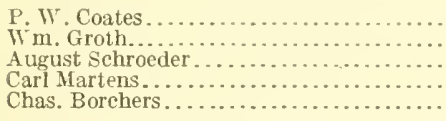 & 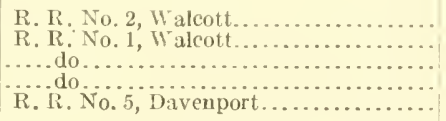 & $\begin{array}{r}25 \\
10 \\
44 \\
108 \\
42\end{array}$ & $\begin{array}{r}15 \\
3 \\
10 \\
3\end{array}$ \\
\hline
\end{tabular}

Many other so-calley hog-eholer:a lemelies have been tried, with results equally disappointing.

4. Hog cholera is no joke. 'The mam who thinks he can let the disease pun its combe and sare most of his hogs is generally doomed to disaplonintment. Natural and inherited immmity is all that will sive him. He who saves over 15 per cent is fortumate above tle :lrerage.

What cholera does when allowed to run its contse.

[Nearly all of these herds were fed some commercial feed or tonic.]

\begin{tabular}{|c|c|c|c|}
\hline Name. & Aduress. & $\begin{array}{l}\text { Number } \\
\text { in herd. }\end{array}$ & $\begin{array}{c}\text { Number } \\
\text { lost. }\end{array}$ \\
\hline 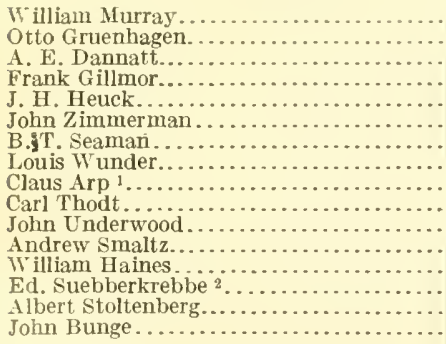 & 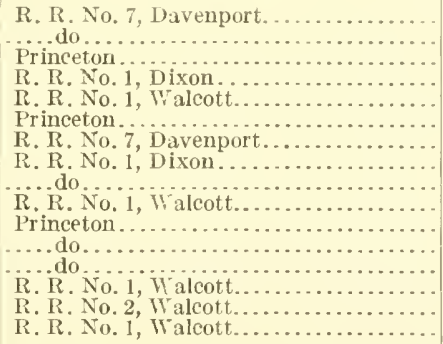 & $\begin{array}{r}95 \\
60 \\
130 \\
138 \\
70 \\
58 \\
76 \\
80 \\
121 \\
90 \\
95 \\
80 \\
80 \\
120 \\
35 \\
102\end{array}$ & $\begin{array}{r}84 \\
60 \\
129 \\
132 \\
69 \\
55 \\
71 \\
76 \\
42 \\
86 \\
87 \\
52 \\
50 \\
60 \\
29 \\
99\end{array}$ \\
\hline Total ${ }^{3} .$. & & 1,413 & 1,201 \\
\hline
\end{tabular}

1 From immune sows.

2 Mule foot hogs.

385 per cent loss.

5. In most cases a mall does not lealize how sick his pigs are at first and neorlects treatiug them until it is too late.

6 . The success of the serum treatment depends upon the following factors: Strength and cleanliness of the sermm, amount of disease in the herd, amonnt of natural immunity present, coolness of the weather, cleanliness of the premises, kinds of feed given, etc.

The three most important factors which deternine life or death are all variable and almost impossible to control. 'They are the strength of the serum, the deaclliness of the cholera germ, and the anount of natural or inherited immunity present.

7. A pig sick with cholera needs clean quarters. no dust, plenty of cool, clean watel, fresll slop or milk, good pasture (clorer or alfalfa is hest), and no corn. 
8. The symptoms of chronic cholera are as follows: Loss of appetite, coughing, hard breathing, constipation, and disposition to lie in sheds in the early stages. As the disease progresses the curl leaves the tatil, the ears droop, the animal gets thin alld wealk, staggering as it walls, the ereball is bloodshot and the eyelids often smmmed nu, so that the pig acts as though blind. Sometimes the heat is held to one sitle. In the last statges the bowels are very loose and the excrement green and watery.

sirum in well herds.

The treatment of well herds has been attended with the largest success and the smallest losses. This is the method which shonld be used when cholera is in the neighborhond. If one is reasonably sure that he has reliable sermm, either the double or simultanenus methot slould be adopted. The former is safer if me isn't slle of his serum, as there is always a danger of a loss from the simnltineous methol. 1. F. (Gillmor lost 20 per cent by this method.

This will undouldedly be the chief method used in the future in combating how cholera. It gives immunity for life except when used in suckling pigs. When used on pigs which have heen weaned for about a week it is much less expensive than where the pigs are nearly grown.

The following 10 well-known farmers of seott county have used this method on their herts, totaling 2.700 heat, this seatson, with a fotal loss of ouly $3 !$ prigs:

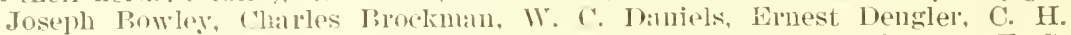

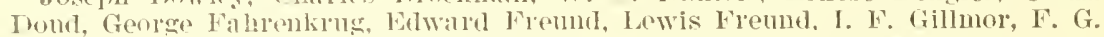

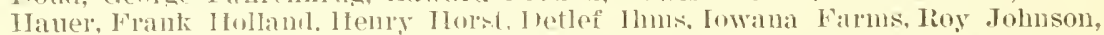
Waren Johnson, Ienry Kinz, Henry Klinlt. (Whules Knouse, ('harles Kreiter,

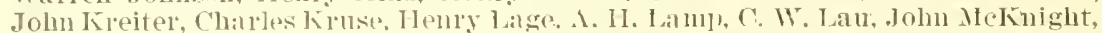
Julius Muhs, Willian Myer, Orphans Ifome, I1. D. Parmele, William Pieper, Chris Laabe, Cart schnekloth, le loy Schutter. W. D. Scott-only given single treatment; immunity las rum out-lewis stichier, R, $\lambda$. Strong. Untielt Bros, Juhn Toss, Ifemry Wiesu, nietz Wriedt, Wiese bros.

slightly affected herds-siugle treatment given.

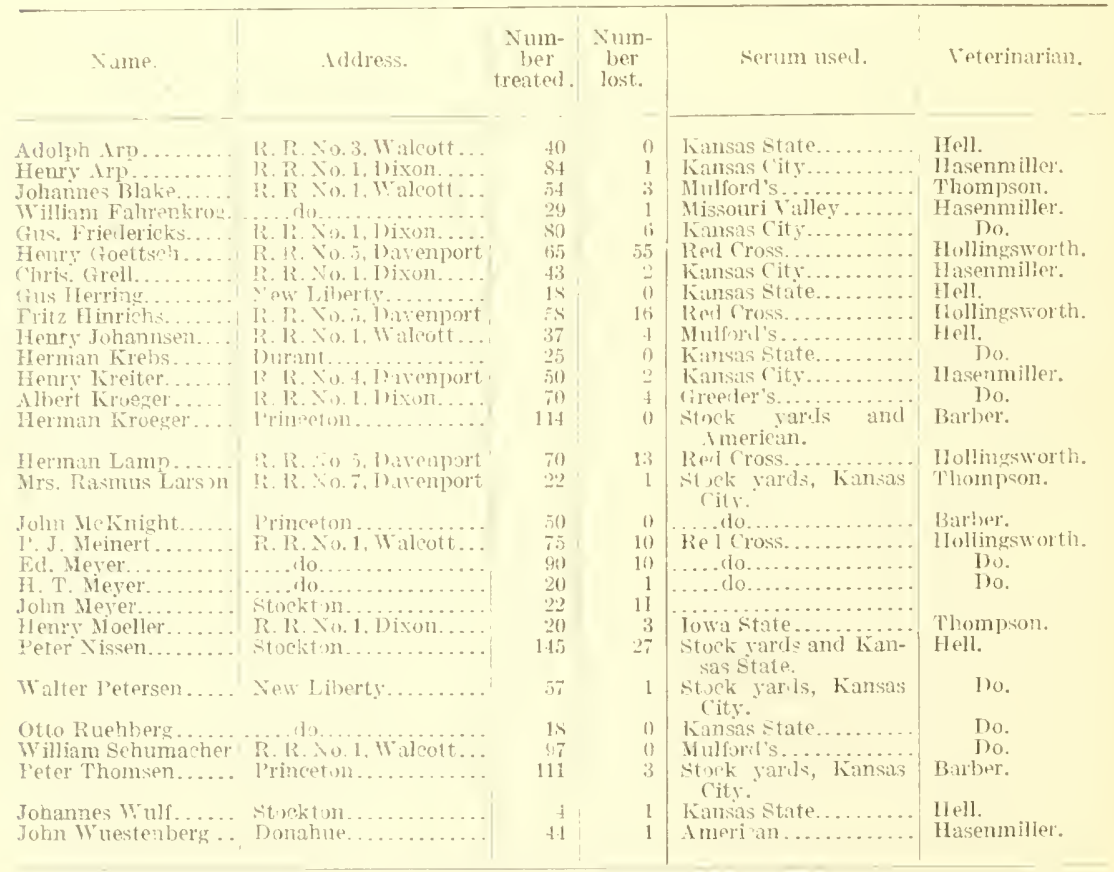

Mr. Blake's herl was not sutheienty insected to boll its immunity, Sereral are now sick and 3 hare difd. They las e bepn treater amin. 


\section{Ilerts quite sick-Single treatment given.}

[Shoull have been treated 3 or 4 days sooner.]

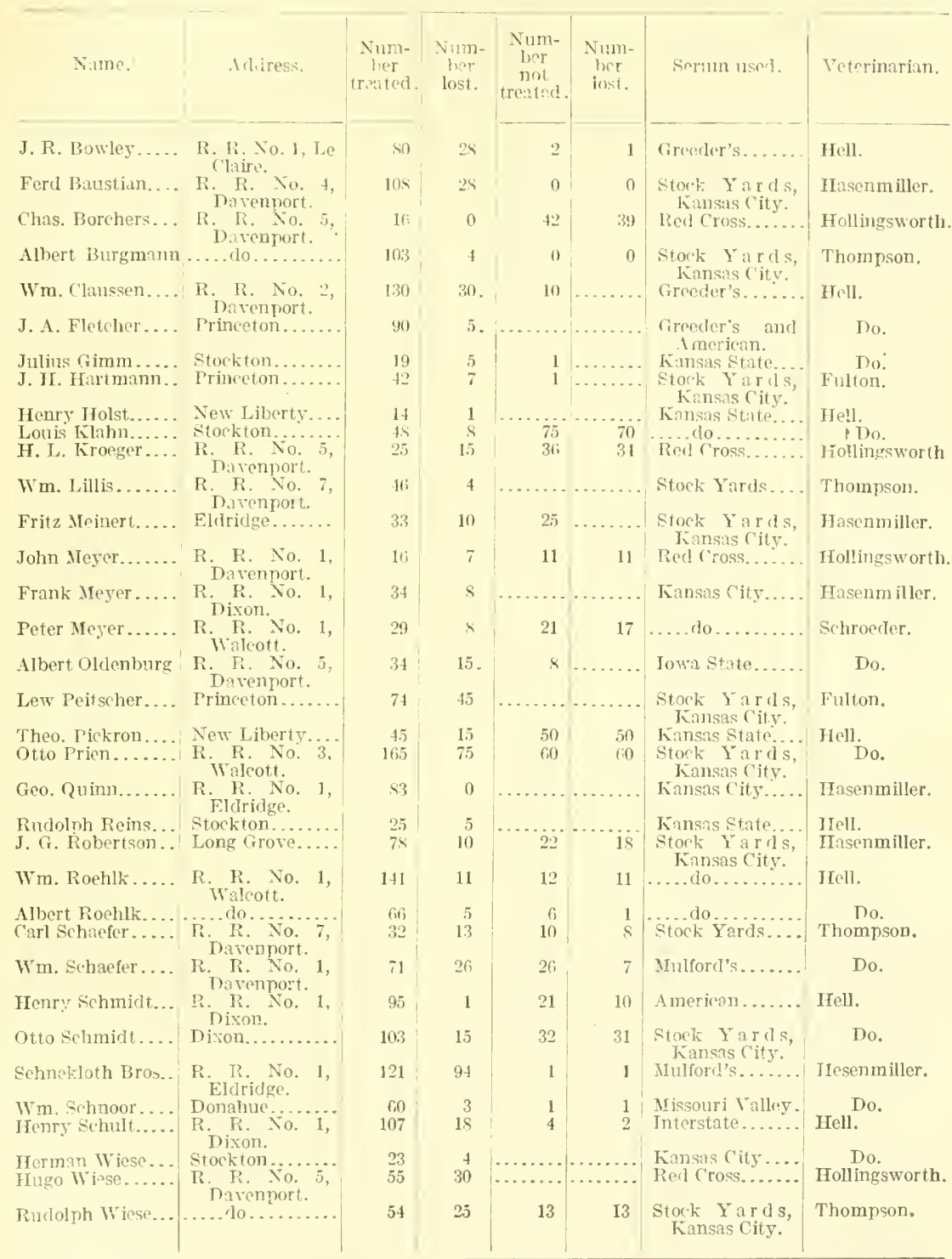

In adrlition to those mentioned above, Frank Friedrichs, Barney Gasseling, Rudolph Golinghorst, IIans Kunl, W. F. Paul, James Porter, Louis Steinbeck, and several others have nsed serum on quite sick herds, but the resilts have not heen reported.

S. Doc. $459,63-2-4$ 
IIerds very sick-Single treatment given.

[Should have been treated 10 days sooner.]

\begin{tabular}{|c|c|c|c|c|c|c|c|}
\hline Name. & Address. & $\begin{array}{c}\text { Num- } \\
\text { ber } \\
\text { treated. }\end{array}$ & $\begin{array}{l}\text { Num- } \\
\text { ber } \\
\text { lost. }\end{array}$ & $\begin{array}{c}\text { Num- } \\
\text { ber } \\
\text { not } \\
\text { treated. }\end{array}$ & $\begin{array}{l}\text { Num- } \\
\text { bet } \\
\text { lost. }\end{array}$ & Serum used. & Veterinarian. \\
\hline Vietor Blyart..... & R. R. No. 1 , & 55 & 30 & & & Stoek yards, & Hell. \\
\hline A. E. Dannatt.... & Princeton....... & 23 & 23 & $12 \pi$ & 126 & $\ldots$. do.......... & Fulton. \\
\hline James Donnelly.. & $\begin{array}{l}\text { R. No. } 5 \text {, } \\
\text { Davenport. }\end{array}$ & 15 & 15 & 0 & 0 & ...do......... & Thompson. \\
\hline William Dubois. . & Princeton....... & 106 & 91 & $2 !$ & 21 & Huber's. .. . & Barber. \\
\hline George Frauen.... & $\begin{array}{l}\text { R. R. No. } 3 \text {, } \\
\text { iralcott. }\end{array}$ & 87 & 47 & 8 & & Mulford's.. & Hell. \\
\hline Otto Gruenhagen. & $\begin{array}{l}\text { R. R. No. } 7 \text {, } \\
\text { Davenport. }\end{array}$ & 18 & 17 & 60 & 60 & Stoek yards, & Hasenuniller. \\
\hline Frank Gillmor... & R. R. No. 1, & 65 & 59 & 73 & 73 & ....do............ & Do. \\
\hline Carl 1]amann..... & R.R. No. 1, & 46 & 12 & 60) & 56 & irepder's...... & Hell. \\
\hline Ed. Helble. . & Princeton...... & 40 & 26 & & & stock rards, & Fulton. \\
\hline Ed. Horst........ & $\begin{array}{l}\text { R. R. No. } 5 \text {, } \\
\text { Davenport. }\end{array}$ & 40 & 39 & 60 & 60 & .....do.... & Thompson. \\
\hline J. H. Heuck..... . & R. R. No. 1, & 9 & 8 & 71 & 70 & 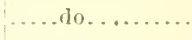 & IIell. \\
\hline Chris. Jaegers. & .... do........... & 22 & 14 & 45 & 44 & & Sehroeder. \\
\hline Wm, Liliential... & Sunbury $; z . . .$. & 16 & 13 & & & Jorth Western. & llell. \\
\hline William Moeller.. & R. R. No. 1, & $5 \mathrm{~s}$ & 14 & 2 & 2 & Red rross....... & Do. \\
\hline $\begin{array}{l}\text { H. Peckenschnei- } \\
\text { der. }\end{array}$ & R. R. No. 3, & 59 & 27 & & & ireeder's.. & Do. \\
\hline Otto Prien....... & ....do......... & 165 & 75 & tit) & 60 & $\begin{array}{l}\text { S toek rards, } \\
\text { Kansas rity. }\end{array}$ & Do. \\
\hline Theo. Sehroeder.. & R. R. No. 1, & 31 & 16 & tio & $4 i$ & Mulford's...... & Do. \\
\hline F. G. Wessel. & long lirove.... & 77 & 25 & $x$ & 2 & Interstite... & Hasenmiller. \\
\hline Henry Tank.. & $\begin{array}{l}\text { R. R. No, } \\
\text { Davenport. }\end{array}$ & 17 & 9 & & & $\begin{array}{l}\text { S t o c k rards, } \\
\text { Kansas City. }\end{array}$ & Thompson. \\
\hline
\end{tabular}

In addition to those mentioned atove, A. P. Arp, Domeherty Bros., Lewis Frauen, Ed. Frell, Fred Koberg, Henry Wartens, William stutzel, and several others liave treated very sick herils, but no definite reports have yet been received.

Note,-In all the above tables the name Hasenmiller refers to the firm of 11 ascumiller \& Sehroeder, of Eldridge.

AMES, IOWA. TORMbCr 25, 1913.

Hon. Williad S. Kengon, Washington, D. C.

Mr DEAR SENATOR KENYON: I returnel to Ames yesterlay after an official absence in the East. It was my great nisfortunte to be array from Ames when yon called here, and to fail to find you in Wrashingtun before rour return there. I am glad that jou cimle to Ames, and hole you silw erergthing you were interested in, and I will be rely glad to have gon malie any comments, suggestions, or criticisms to me of conditions as you found then.

I was rely nicely entertained by gour Mr. Rankin and want to express my appreciation of his kindness.

I wish I could have talked with you about the proposed legislation in the interest of hog-choleri eradication. It soens to me thit if the Tuited States Govenment is going into the business of producing log-choler; serum, a rery large aubunt of money will need to he provided. I an wonlering if, with proper supervision. such as has been lloviderl duling the last year or so, and with enlargement of efforts in the states in the interest of servm mannfacture, it will be necessars for the Gorelmment to mulpotake this phase of the work further than to give it a temporaly impetus.

But I have $n 0$ doubt as to the advisability of such demonstration or eradication work as is being done in Dalias comnty and in selpoted counties in two or three other States. I believe the Government can afford to spend a large amount of money in showing the practicability of keepins a considerable area free from the disease. The mistake should not be made. howerer. as was done last year, of holding the new applopriations nutil July 1 . The money ought to become arailable early in the sluing bofurs the diseise begims to spread. One dollar then is worth several later. While the mannfilcture of serum is very-important. I am inclined to think that. with the limited amount of money 
the Government may spend along this line, the demonstration and eradication work is of greater importance, provided the Gorernment makes serum for its own work or can arrange to buy it from state or private plants.

Very truly, yours,

R. A. Pearson, President.

Senator IV. S. Kenyon, Washington, D. C.

Clarion, Iowa, November 5, 1913.

Dear SEnator: I take this opportunity of expressing my appleciation to you for the bill you introdnced, which will give aid to the farmers of the country in combating hog cholera. This bill will provide ample funds for the employment of connty men to take the initiative in combating this dreaded disease.

I began the work as counts agent in Wright County June 1. Since then I have devoted my entire time to the treatment of hos choler:a and the educational work necessiry to acqualint the farmers with facts concerning serum treatment. As a result of the work done in this country we have in the neighborhood of 20,000 hogs that have leen successfully immunizerl against cholera. Had reliable, tested sernm been avalable at all times, we could have saved at least 10,000 more hogs.

The farmers of Wright County lave supported this movement. Had I been able to enlist the services of four other men there would have been plenty of work for all combating hog cholera. I have had the cooperation of five graduate reterinarians, which has helped greatly in taking care of the urgent demands for assistance.

The farmers of this comnty are financing this proposition without Govermment aid. I beliere we have an application on file at Washington, D. C., for financial aid, which we are promised will be given as soon as fumds are available.

I am sending ron, under separate cover, a circular published by our department. This circular gives an outline of the different lines of work we are promoting.

Thanking you very much for the thoughtful effort you are putting forth for our great state of Iowa, I am.

Yours, very truly,

L. O. WISE, Wright County Advisor.

College of Agricultere and Mechanic Arts, Almes, Ioura, October 3/, 1913.

Hon. W. S. Keniox, Wrashington, D. C.

My Dear Senator: Won't you kindly send me copy of youl so-culled hogcholera bill. which I have seen mentioned several times in the papers?

Probably you know that the work against hog cholera is maling good progress in Dallas County. Chief bindrance seems to be that the lederal people do not have enough serum. We have now offered to assist them by giving preference to requests for serum from Dallas Connty when approved by the Federal representative. But we are obliged to charge a small price for this serum, as we have no provision for free distribution. Our new plant is making an excellent start, and the serum allealy sent out has done great good. We are increasing the output.

Very truly, yours,

\section{R. A. Pearson, President.}

\section{Novearber 24, 1913.}

Hon. W. S. Kexiox, Washington, D. C.

Dear sir: Knowing that you are deeply interester in the lug-cholera situation, as it stands now, and that you are trying to help the Government to solve the problem of combating this disease, and that gon contemplate asking Congress to malie a large appopriation to help in this matter. I am taking the liberty to address you moon this subject, hoping that you will fralon me for making this intrusion upon your time and that you will consider my suggestions given in a spirit of honesty and for the purpose. if possible. to heip rou get at facts. I selld you, under separite cover, a little booklet containing a history of hog sicliness back for half a century, a description of things I have seen and 
learlled in my researull against hog sickness. I'lease do me the kinduess to note carefully facts which I have set forth in this little work. I Inve spent my own time and money when making these investigations, and not the money of any state or (tovernment. I have done this in the interest of science and for the good of my luofession. I know, senator, that the diagnosis, as made of this diseas loy the stoft of the liurean of Animal Industry, is not correct. neither is their remedy. and seven years of work on this line of attack las moven it

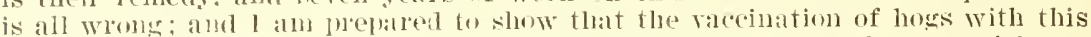
selum treatment las killed thomsands of woll hoss on farms where uo sickness or losses had accurred before. My little houklet will explain all this. I say, my boklet sells for sind. It makes no differente to me whether I sell a copy or not, and I am giving away humdreds of them; tut I hat it colyrighted, and in doins so I had to put a sale frice upon it. Its object is to explain to hog yaisers as to the callse and prevention of hor sickness. Now, in conclusion, Semator. let me sily thonsands of people, not in our own state alone but in other states. are watching with sreat interest if yom make the more on this matter in the right direction. And I think you oinght to luoced callofily. If you

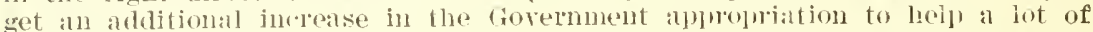
these fellows who are comnected with the Burcan ut Animil Imdustry to go on a few years more and hoost this selum treatment and luave a rood time while at it. it will put thousiunds of good hog jaisers out of business. The fact is, Senatur, the fometen of Animal Industry made a guess and made it wroms, but they can't batck nl, now. 'They ought to call this bet oft' and aness anain. 'The swine lueeders ale soing to origanize and firlit it to a man. If you can set an

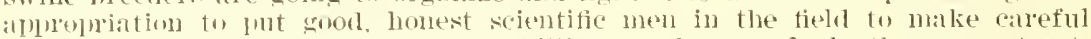

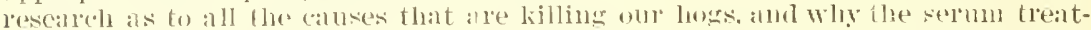
ment has lilled and is still killing thousiums of well hogs, and tell our Government departments of these important facts. and eduente the hog raisers to aldopt the methods of sanitation, and all otler loelpful methods, as set forth in my lowklet - to destroy wolms and internal farmsites and the importance of leeping then healthy all the fine, and use every means to prefent mulealthy conditjons anong their heds-the guestion is solved at once and this awful fatality and losses will stom. Thanking you for vom interest in this matter amel again

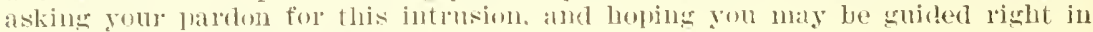
gour efforts in this matter. I am

lomis, resjectfully,

F. F. I,OWRY, V.S.

Hou. W. S. Kenyox, Hashingtom, D. C.

I)EEMBER 17, 1913.

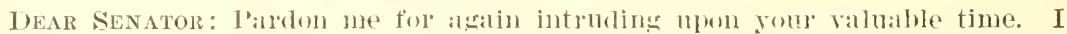
know that you are a very husy mau, but I am so thuroughly aromsed over the situation as to the hog sickness in our own and in other neighinoring Ntates that I can not refrain flom writing you angin. Since l last wrote voul and sent you my little booklet I lave not been idle as fo stulying the comblitims, more especially here in on wrn state. I have writlen to and recejved letters from rolible parties in nearly half the connties in on state. and l find the conditions alpalling in the sections where most serum has been used. There the losses have been greatest. and I, as well as other veterinarians and latre numben's of hog laisers, alte tholonghly convinced that the indiscriminate use of bad serum in the hands of youmg jecentls graluated reterinarians, who have settled in onr State in the last two years, has been the means of spreading the disease into distriets not bofore affected. Thus thousands of hogs have been made sick and disease has spread and muliplied until there is not a county in this state free from disease and deith.

Thousands of well hogs have been vacomated and began to sicken and die immediately. This is mo idle talk. senator. I latve the name's amd post-office addresses of good men who have told me of their losses of this kind. and I know it is true. In ny own comnty une man had 1 ho well hogs valecinated and in 12 days 140 of them were dead. A neighlor had 69 well ones treated thes same way and lost all but $12 \mathrm{in} 14$ days. 'This is only part of this lind of loss in this county. Around Feotal humbleds have leen killed the same way. In Dallas County a malu near Grimes had 100 well hogs vacoinated by a man called a Govermment expert and with a strmin 0 . Kod as the best they were using up

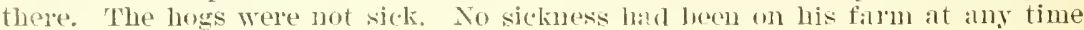
luevious. All but 5 died in a short time. Is Mills County a man had nearly 
300 treated. Nearly all of them dierl. alld he has hought suit against the reterinary who treated them and the firm trom whom he obtainer the sermm. The case is now pending in the district cont of Mllls Countr. The same thing occurred in Muscatine Comnty, and the case is penoling there. In on tomship

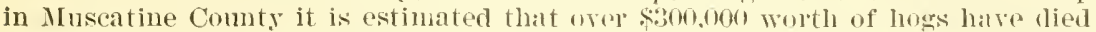
after they were vacoinuter and at lenst lallf of these wele not sick, Jut were given the treatment as a preventive. Now. Senator, these are facts and are only a drop in the bucket to what I cant tell gon funther.

Now, what is the trouble? First, people who ale manufacturing serum and those who are using and boosting it call everything cholera. Nll other ailments that are affecting hogs, such as worms, typhold ferel, pnemmonia, and half a dozen other ailments, are not moticen by these people. 'The whole business has turned into a erraft game and is causing millioms of dollars of unnecessiry loss and sprear of disease. Why not: Almost every packing plant in the country is turning ont this stuff. Wven Joln Morvell \& Co.. of my own city, is now making it. Twenty-two concerus ale making it allound the packing plants of Kausas City, 18 or 20 at Omalu, and so on. Semator Kenyon. I have spent my own moner in obtaining these facts. not the mones of the State or National Govermment, and I have plenty of facts. Now, I helieve that, like myself, you mean right when rou take the interest in this matter that you do, and for the sake of the hog raisers and for the sake of the honor of our own State, and your ow honol, do not ask Comgress to alumopriate any more money to aid the selum graft.

I believe the Burean of Animal Industry meant right when they put this move into operation. but tests have proven it to be a fililume, and it is now beyoud the control of state or Government. If there were any efficiency in it, we have no way to prove it now. The first thing that should be ane is to stop the nse of it entirely. If this is not dome soon. the swine-raising industry will be ruined. I know you mean well ant will do what is right, but it would be well to proceed cantionsly. An appropriation of $\$ 1,000,000$ to determine how to prevent sickness in herds would he moner well slent, even if it took that each year and we aot the desired results. To appropliate money to help the sorum treatment along is worse than pouring oil on a buming fire. If I were a rich man and wanted to be a real philanthropist, I would suend $\$ 10,000$ to stop the use of this stuff at once. Then get busy and show hog men that this disease can be stamperl out. hut not by semm methods. Besides thousands of hogs would and do get well of themselves if let alone when they get sick. And thousands of others can he cured with the use of right remedies in the hands of men eompetent to diagnose disease in sick hogs and use the remelies indicated by the sickuess to be treated. What I know about this disease I have learned by scientific research and at my own expense.

Do not be influenced by a lot of wiremulling politicians who are holding positions in our Govermment dejartments by the apjointment method and not because of homesty or alility. All of surb mell will still do all they can to get you to assist them furthel in this useless, dangerous work. Hoping ron will look deeply into this mitter and will help to stop the use of serum at least long enourin to get some control of its ontput and use, and that rour efforts in this present session of Congress will he such as will aid us to get at the moper way to make sick hogs well and keep well hogs from getting sick. and not to add any further in the use of serum graft, and again asking your pardon for further intruding upon your valuable time. I am.

Yours, most sincerely.

E. F. LowrY.

Haye Fatil in serum- Wrigit Colnty Farmers lino Lost Maxy Hogs in

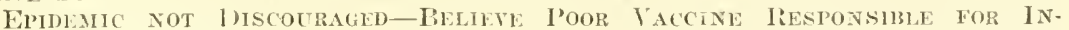

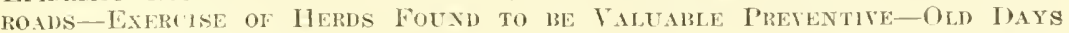

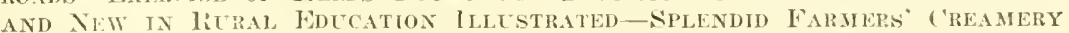
at CLARION-WHLSON`S IRURAl MLSERVATIONS.

[Special to Times-Republican.]

Clarion, Jumuary 13.

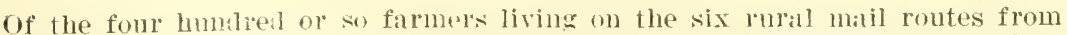
this town. the nanles of those who escaperl al risitition of how cholera last summer and fall might he enumerated on the fingers of two hamb. Practically 
every hog raiser had his experience with the disease. One man well posted on the matter estimates that one-fourth the usual suply at this time of vear is left as the result of disease and close selling longht abont because of it. In the neighboring town of Woolstock, it is said, a buyer collected a calloald for shipment, but instead of going to a packing plant evers animal of the load fomd its way into the pork barrel of a local farmer. Nearly everyone who was able to get serum vaccinated his hogs. Neally eversome who vaccinated believes in the efficacy of the remedy, eren thongh he lost most of all of his hogs, and it is a fact that the losses of hors thus treated in the early part of the season were hears. Failure of the treatment to save the animals is generally attributed to inexperience in the work and to untested serm. Iate seison work dome by a trained man and with tested serum produced almost universally lavorable results, and many who lost large umbers of their :mimals this yea declare they will administer the donble treatment to the next crop at weaning time, confident that immunity will lesult.

It will not 30 , howerel, to state positivels that it was vaccination that saved the hogs in every case. Sureral who rid not enimloy the method at all were able to save a greater or smaller part of their herds. One of these, who fom sickness in his yard. "vaccinated" the three or four afllicted porkers with an ax, and proceeded to doctor the remaining ones with a remedy that he heard was good. viz, red pepper. He fed up an even dollir"s worth of the fiery stuff, and up to last week he had not a sick hos on his place, a carload of the thriftiest kind of fellow being in his feed yads. Nnother man lost only 1 hog of a herd numbering ahout 90. A breeder of pure-bred hogs in another locality adopted a plan of his own. He malle it a part of his chores to get ont in the morning and "exercise" his hogs-lan them all over the pasture. At the same time he fenced off part of his colnfield and turned the hogs into it. He has just hold a hog sale on his farm. Sail one man: "I believe hog cholera might be prevented ly keeping the stock in fresh ralds and pastures, changing them "very year or so." One thing is cortain : there lus been a lot of thinking on this subject of hog thease this year in this part of the country, and if next year's crol' is lost it will not be beanse of carelessness or ont-of-late methous on the part of the farmer.

CoMpel Use of SERTM-COL. Frexcli, of Davenfort, ADYocates CoMpulsory

INOCULATION OF HOGS-WANTS STATE TO EQTIP LABORATORY TO COST \$250,000 _

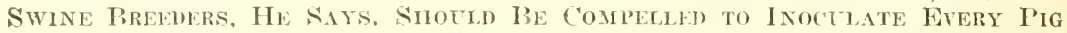

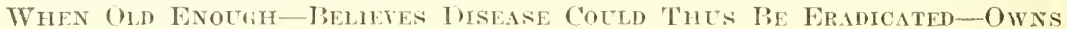
Herd of 1, UOO AND Noxe ARE Lost.

I AVEXPORT. November 8 .

Farmers and veterinary surgems who hare studied the ravages of hog cholera in Iowa the past year extimate that the total loss will not be less than $\$ 15,000,000$, and some place it as high as $\$ 25,000,000$.

Col. George W. French, of Ibivenport. proprietwr of the Inwana stock farm, urges a compulsory system of incoulation. which he thinks will in a few rears banish the disease from the State. Ile has 1, (m) hogs, valued at $\$ 30.000$, all of which have been inoculated with sermu and not one has died from the disease. He wants the legislature to alpropriate $\$ 250,000$ for the purpose of establishing a serum factory large enough to prodnce suflicient serum to supply all the farmers of Iowa.

COMPLLSORY INOCULATION.

He would then have the legislatme pass a law making it compulsory upon farmers to inoculate every log in the State, following this np by inoculating every pig as soon as it is old enough. In three or foll genelations of hogs, he thinks, the disease would be stamperl ont.

There has heen much eritioism of the last legislatme becaluse of the small amount appropriated to establish the serum factory at Ames. This plant produces hardly enough scrum to treat the hogs of one rounts, to say nothing of the rest of the state.

KILL IIOGS ONIY TO SAVE.

Despite the fact that 30 hogs are being sacrificed weekly at the Minnesota Agricultural College in Minneapolis to llodnce serum that other hogs may be made immune from choleril, which is still frevalent in westem and sonthwesteln comnties of dlinmesota, 11. Preston IIoskins, assistant veterinarian, in charge 
of the serum department at the miversity farm, helieves the loss to Mimmesola farmers this year will be $\$ 5,000,000$. He declared a large amomnt of the llloney would be sjent for worthless medicines.

Enough serum can be obtained from one hog to inoculate 500 weighing 100 pounds each. In getting the serum hogs immune from choleral ale used. Inimals that have recovered from the disease or have been given the seluml-yins treatment may be taken for the purpose.

These are rendered hyperimmune by being treated with rilus male from other hogs. The blood of the hyperimmune animal has been fombl to comtain a large amount of the substance that protects animals from attacks of choloris. From this blood the serum is made and sent to log owners in all parts of the State to protect exposed herds.

Late Start Mars Hog-Cholera Tests, but Government mxpriments at ADEL SIIOW VALUE of WORK-J)EMAND Is Growing-Farmers TaKiNa More INTEREST AND ARE AMING FXPERTS.

[By Edgar Markham, staff correspondent.]

ADEL, IOWA, October 1\%.

The first rear's resilts in the Govelnment experiment to determine whether hog cholera can be controlled will not he what was antivipatel. Init they will show that fully so per cent of the hogs of diseased herds can he sared if given the serum treatment. They also will show that few hogs are killed by the simultaneous treatment, which is the one given to prevent the diseise.

The reason that the restilts of the experiment will not be entirely satisfac. tory is that the aisease got ahear of the Govermment ficld corps which is working under the direction of Dr. O. B. Iless. The appropliation male by Congress was not arailable until July 1. liy that date hog cholera was prevalent in many communities.

C1IOLERA HAD GOOD START.

When it was amounced the experiment was to be made it was said that only the jueventive treatment would be given. The pmpose was to demonstrate that choleral can be controlled by the use of virus and serum, not that it can be cured by the use of semm. But so many hogs were infected that it was found necessary to help save the sick ones.

Dr. James I. Gibson. State reterinarian, was in Dallas County to-day in conference with Dr. Hess. He is cooperating with the Government in the experiment. It is his duty to watch the sanitary end of the work. Quarantine regulations frevail on ('very firm where it is known that choleral exists or where the simultaneous treatment has leen griven.

"I alm well satisfied with the jesults that are being obtained." 1)r. Gibson said after spending a day in the field. "Nr. Hess and his assistants are doing their best to get the most ont of the experiment. They certainly are doing a great thing for the farmers."

\section{FARMERS ARE COOPERATING.}

Ralph E. Jos, who is secretary of the county organization, reported to Dr. Gibson that the farmers are cooperating with the Government. There are a few stubborn ones who oppose the ise of serum, but not many.

"As an illustration of the interest the farmers are taking in the experiment, I might say that 1 am called over the telephone all hours of the day and night to send ont field men to administer the sernm," he said. "All I do is to try to gather data from the farmers that will lelp in the experiment. Letters have been sent to every farmer in the county."

Close to 8.000 hogs have been treated by the Government field men. A majority of these were found to be diseased. From the reports prepared between 15 and 20 per cent of the diseased hogs have died. Few of the others succumb to the treatment.

\section{REQUIRES BUT LITTLE TIME.}

The field men have been in idleness half of the time. Recently near Dawson 457 hogs were treated in eight hours. The experts can administer serum to a hog a minute if they hare the help needed. 
At the home of W. H. IIathawar, 3 miles north of Redfield, 97 logs were given the treatment in less than two homs. Twenty mor were treated at the George Munlins farm, which is near by. All this was tome after 30 clock.

Dr. ITess uses three assistants. Tho farmers are expected to furmish enongh help to catch, hold. and prepare the hoss for treatment. Seren men are needed. One of IMr. Hess's assistants talies the temperature of the hog.

If it is below $104^{\circ}$. the simulaneons treatment is siren. Above that mark the log is considered sick. He needs no vilus. If the disease has not made too much progress the serum will cure him.

TEMPERATLRE DETIRAINES AMOLNT.

From the temperature of the hog Dr. Hess determines the amount of serum to be alministered. The size of the animal also plays a big part in cletermining this. One assistant prepales the serum and viris for injection. The third assistant keops the records. If the temperintme of a hom is found to be more than $106^{\circ}$ he is malked. This is dome so that Tr. Hess may know whether mans of those in the late stanes of the discase are cured.

Ais idea of the work lor. Hess has before him ean he gained when it is known that he this afternoon refused to promise a farmer he could get to his herd in time to do any good. M. 'T. Pairlekouper. who lives neal liathaway, reported sickness in a herd of 150 head.

MUCH WORK AHEAD.

"I might momise som, but I wont beanse I know I can not keel) it," Dor. Hess said. Ile called attention to helds angregating 2.0no heat in which there is sickness.

Dr. lless advises the farmers to hire their logs treated rather than to wait for the Government nen. The expense is about \$1 each. The Government makes no charge. Some of the farmers liesitate lecause one or two incompetent reterinarians have alministered the treatment in the comntr.

At their conference Dr. Gibson and Dr. Hess were mable to reach a conclusion as to what canses the disease to spreal as rapidls as it does. Pairdekooper declared that no cholera had existed on his fam since he has lived there-for five years. Not a strange hog has heen on the liace during the summer. Two weeks ago, however, he drove a carload of hogs to market. Diseased hogs had been put in the stockyards. In. Hess said that I'airdekooper may have carried germs home on his clothes.

Three famers got cholerar in their herds by hauling hogs to a shipping place where cholera was prevalent. The wagons and horses carried the germs to the swine lens. Dr. Iless said.

Dr. Iless and Dr. Gilson ale sure that by getting an ear y start in the spring they will be able to coutrol how cholera in Dallas comntr next summer. But they don't want to wait until they are put on the defensive before they start fighting.

OFFICLAIS TPY TO QLARANTINE SIINE-TOLR OF DALLAS COLNTY TNDERTAKEN BY GILSON AND FEIVERAL EXPERT.

PERry, Iowa, Orotober 2\%.

Dristic measures to merent the spread of hog clolera were abonted yesterday when several state oflicials started a tour of the comnty to place in quarantine every herl of hoss exposed to cholera.

Dr. James T. Gilsom, state reterinarian: Tr. T. W. Iamman, of Bloomfield, member of the State animal lealth boarl: Dr. Hess. a rovermment expert in charge of the work in this comnty : and Henry Pridy, member of the legislature, composed a party of men who left hele this morning on a tour of the counts.

They are josting motices and doing everything possible to prevent the spread of the disease. The quarintine notices read:

" Palties having business on these premises must keep away from the hog lots. Parties occmping these premises are forbillen to go in or near their neighbor's' hog lots."

According to the state and Fedelal anthorities. Dallas County has more hog cholera this rear than ever before in its history. Federal aid was given some 
time ago, and Dr. Hess and his assistants have been working for weeks to prevent the disease. In many instances they have been very snccessful, but in other's they were notified too late to save the herds and confined their efforts to rendering immune the hogs on the neighboring farms.

They have been handicapled by being umable to secure serum when it was most neederl. and conditions are such now that the most drastic measmres are necessary to stamp out the disease.

SERUM PLANT SATISFACTORY-LEGISLITORS' ONLI REFRET IS TIIAT PLANT IS NOT LAliGER.

[Special to Times-Republican,]

DEs MOINES, Jamuary 10.

Members of the legislatme hase been well pleased with the state bos-serum plant in operation at Ames as provided for hy the legislature. Several members have taken occasion to visit it during the short-conrse period at the rollege.

Speaker Cumningham. who was in the city yesterday, had just come from the college. "The serum plant is all right." he said, "only we have got to malie it rery much larger in order to do the business. I nerer saw a plant whele they have everything in such excellent comdition. And they have the records. too, of every shipment and can show exactly what results were obtained in every case."

Representatives Huntley, of Lncas, and Brady, of Lallas, also in the city this week, spoke in praise of the work being done.

"I have made a thorough investigation of llie sernm ilant at the college," said Senator Ames, of Tama, who led in the fight for its establishment. "The only mistake we made was in not giving pnongh money. They shonlu be able right now, at the dull time, to be maling vast quantities of the sermm to be kept for use when needed. It looks like the falmers will have to cone to their help by buying in adrance and mutting up the money. But it is a great institntion and everything simply pertect. I went through the laboritories at Kansis City, and in coitrast thint at Ames is a delight. I am absolutely slire of the value of the plant and the work being done."

PROF. G. R. BLISS ON IIOG CHOLERI-IOWA AGRILLLTURAL EXPEIT ADVISES IILINOIS FARMERS-APPLIES TNIQEE METIIOHS-WACERS TILT HOGS PROIERLY TREATED WILL NOT GET CHOLERA FROM DISEASEIS $\triangle$ XIMALS.

Monmouti, Decrmber 11.

G. I. IBliss, comty agricultural arvisol of steott Connty, Iowa, in which Davemport is locitol. is not a betting man, but lie male a wager of \$100 cold cash at the Meror comnty Farmers Institnte meeting resterlaly aftemon that if all the hoss of Merrer and IVaren connties were inoculated with fresh hog-cholera serum just after tley are waned. nsing tlie double treatment, that not one of the porkers wonld die, even thongh placed in a herd of diseased hogs. Mr. Bliss male the same bet with tarmers of scott County when clolera was killing oft the hors ly the lmmberls in that county a year ago, and he still retains possession of his oriminal bank accomnt-and more.

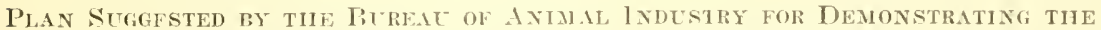
Bist II tilods of Controllixi Ilog cholera.

\section{METHOD OF PROCFDIRE.}

I. Educational work.- To be curiesl mut jointly by Federal and stato officiols thounh lectures and demonstrations hefore famers clubs and suecial assemblages:

II. Restrictive regulations and quanutiur.-Testrictive regulations shonld he issurd ly state anthorities and entored he state officers and United States employees deputized for the purpose. 
III. Immunization with sermm.-This work is to be under control of employees of the Bureau of Animal Industry, and serum is to be administered at such places and in such manner as they may decide to be necessary.

IV. Serum production.-Anti-hog-cholera serum sufficient for the work to be prepared by the Bureau of Animal Industry and furnished to the United States field inspector's upon request.

$$
\text { ORGANIZATION. }
$$

I. Administrative.-The general administration of the work to be under the general direction of the Chief of the Bureau of Animal Industry, United States Department of Agriculture.

II. United states Department of Agriculture.-(a) Field foree.

One supervising field inspector and adviser. The force in each state is to be an independent unit reporting direct to the Chief of the Bureau of Animal Industry and is to consist of :

One inspector in charge.

One or more veterinary inspectors and one clerk.

(b) Laboratory force.

One inspector in charge with the necessary scientific assistants, clerks, and laborers to prepare sufficient serum to supply the various field inspectors.

III. Nondcpartmental.-(a) State officials.

As many trained employees as the state can furnish for field work and lectures.

(b) Volunteer assistants.

As many intelligent farmers as can be secured for general cooperation, to be chosen jointly by the United States field inspectors in charge and authorized State representatives.

\section{COOPERATION.}

Generally the following principles are to be observed:

1. The preparation and apllication of serum will be under control of Federal oflicials.

2. Necessary quarintine and other restrictive measures to be nnder control of the proper State officials.

3. Elucational work to be carried out jointly by Federal, State, and county representatives. 

Gaylord Bros.

Makers

Syracuse, N. Y
PAt. JAN. 21, 1:08 
LIBRARY OF CONGRESS

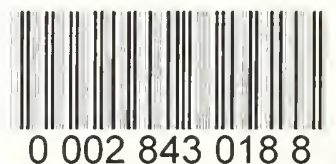

